\title{
THE FOURTH AMENDMENT AND COMMON LAW
}

\author{
David A. Sklansky*
}

In several recent cases the Supreme Court has declared that the principal criterion for assessing whether searches and seizures are "unreasonable" within the meaning of the Constitution is whether they were allowed by eighteenth-century common law. This new form of Fourth Amendment originalism breaks dramatically not only with the ahistoric approach of the Warren and Burger Courts to search-and-seizure questions, but also with an older tradition of using the background of the Fourth Amendment to illuminate not its precise demands but its general aims.

This Article traces the emergence of the new Fourth Amendment originalism and argues that the doctrine has little to recommend it. The Court's revised understanding of the Fourth Amendment is faithful neither to the text of the Amendment nor to what we know of its intent. And anchoring the Fourth Amendment in common law will do little to make it more principled or predictable, in part because common-law limits on searches and seizures were thinner, vaguer, and far more varied than the Court seems to suppose. What the common law has of value to offer Fourth Amendment law is what it has to offer constitutional law more generally: not its rules but its method.

\section{INTRODUCTION}

In the Commons in May 1641 a member said "Antiquity without truth (as saith Cyprian) is but ancient error." It is agreeable that he had to quote an ancient authority in order to reject the authority of antiquity. ${ }^{1}$

Famously short on specifics, the opening clause of the Fourth Amendment guarantees " $[t]$ he right of the people to be secure in their persons, houses, papers, and effects, against unreasonable searches and seizures."2 For most of the past half-century, the interpretation of this guarantee has had little to do with its origins. To identify "searches and seizures" governed by the Amendment, the Supreme Court since Katz $v$. United States has asked whether a particular investigative technique invades an "expectation of privacy . . . that society is prepared to recognize as "reasonable" "3 - a standard that pointedly directs attention to the pre-

* Professor of Law, UCLA School of Law. I thank Benjamin Aaron, Peter Arenella, Robert Goldstein, Mark Kleiman, William McGovern, Daniel Richman, William Rubenstein, Jeff Sklansky, Clyde Spillenger, Carol Steiker, and Stephen Yeazell for guidance and criticism, Michael Lopez and the staff of the Hugh \& Hazel Darling Law Library for research assistance, and the Columbia Law Review for careful editing. I am especially grateful to Thomas Davies for his detailed critique of an earlier draft.

1. Christopher Hill, 'Reason' and 'Reasonableness' in Seventeenth-Century England, 20 Brit. J. Soc. 235, 239 (1969) (quoting William Thomas).

2. U.S. Const. amend. IV.

3. 389 U.S. 347, 361 (1967) (Harlan, J., concurring); accord Smith v. Maryland, 442 U.S. $735,740(1979)$. 
sent, not to the past. In determining whether a search or seizure is "unreasonable" and hence forbidden, the Court since Terry $v$. Ohio has balanced the need for the intrusion against the burdens it imposes-an explicitly functional test, requiring no historical inquiry. ${ }^{4}$ Fittingly, the Court's reasoning in Katz and Terry itself focused on the realities of modern law enforcement rather than the eighteenth-century origins of the Fourth Amendment. Terry's balancing test for the lawfulness of searches and seizures has coexisted uneasily with a collection of per se rules and exceptions that at least in some circumstances require warrants based on a showing of probable cause. But the warrant and probable cause requirements are today defended on grounds of pragmatism rather than fidelity to tradition. The same may be said of the Fourth Amendment's chief enforcement mechanism, the "exclusionary rule" barring illegally obtained evidence from use against a criminal defendant.

History has not always been a stranger to the law of search and seizure. Justice Bradley's majority opinion in Boyd $v$. United States, the Court's first major interpretation of the Fourth Amendment, drew broad lessons from the eighteenth-century controversies in England and America to which the Amendment responded. ${ }^{5}$ Justice Brandeis leaned heavily on those same events, and on Boyd itself, in his celebrated dissent in Olmstead $v$. United States, a dissent that found reflected in the Fourth Amendment "the most comprehensive" and "most valued" of rights, "the right to be let alone." 6 And Justice Frankfurter argued repeatedly and at length that "the meaning of the Fourth Amendment must be distilled from contemporaneous history."7

Boyd remains among the most venerated of constitutional precedents. $^{8}$ In its own way, so does the dissent by Justice Brandeis in Olm-

4. 392 U.S. 1, 8-9 (1968); accord Camara v. Municipal Court, 387 U.S. 523, 534-35 (1967).

5. 116 U.S. $616,624-31(1886)$.

6. 277 U.S. 438, 478 (1928) (Brandeis, J., dissenting).

7. Davis v. United States, 328 U.S. 582, 605 (1946) (Frankfurter, J., dissenting); see Chapman v. United States, 365 U.S. 610, 619 (1961) (Frankfurter, J., concurring); Frank v. Maryland, 359 U.S. 360, 363-65 (1959); United States v. Rabinowitz, 339 U.S. 56, 69-70 (1950) (Frankfurter, J., dissenting); Harris v. United States, 331 U.S. 145, 157-63 (1947) (Frankfurter, J., dissenting).

8. See Jacob W. Landynski, Search and Seizure and the Supreme Court 57 (1966). Justice Brandeis said Boyd "will be remembered as long as civil liberty lives in the United States," Olmstead, 277 U.S. at 474 . Justice Frankfurter called it "the guide to the interpretation of the Fourth Amendment to wbich the Court has most frequently recurred," Harris, 331 U.S. at 160. Alexander Bickel praised it as "a shining and enduring demonstration" of the proper role of history in constitutional interpretation, Alexander M. Bickel, The Original Understanding and the Segregation Decision, 69 Harv. L. Rev. 1, 5 n.14 (1955). For more recent invocations of Boyd, see Brower v. County of Inyo, 489 U.S. 593, 596 (1989); Payton v. New York, 445 U.S. 573, 582 n.17 (1979); United States v. Chadwick, 433 U.S. 1, 11 n.6 (1977); United States v. Watson, 423 U.S. 411, 446 (1976) (Marshall, J., dissenting); Schneckloth v. Bustamonte, 412 U.S. 218, 228 (1973); Coolidge v. New Hampshire, 403 U.S. 443, 453-54 (1971); Terry, 392 U.S. at 39 n.4; Berger v. New York, 388 U.S. 41, 49-50 (1967); see also California Bankers Ass'n v. Shultz, 416 U.S. 21, 61 
stead. ${ }^{9}$ The history lessons taught by Justice Frankfurter, even when he did not speak for the Court, did much to shape current Fourth Amendment law, particularly the rule that searches and seizures without a warrant are presumptively unreasonable. ${ }^{10}$ In recent decades, though, the Court has tended to treat the Fourth Amendment opinions of Justice Bradley, Justice Brandeis, and Justice Frankfurter like vaguely embarrassing older relatives at a holiday dinner, paying them respect but not taking them very seriously. Almost nothing remains of the actual holding in Boyd, ${ }^{11}$ and the Court has gone out of its way to deny that the Fourth Amendment protects a general "right to be let alone."12 The Warren and Burger Courts occasionally recycled the history recounted in Boyd, Olmstead, and the opinions of Justice Frankfurter. ${ }^{13}$ But by the early 1970s the history of the Fourth Amendment seemed increasingly beside the point.

In tying search-and-seizure law to the present rather than the past, the modern Court was in rare agreement with its critics. Peter Arenella voiced the consensus of a generation of criminal procedure scholars when he blamed the "intractable uncertainties in the text and historical record" of the Fourth Amendment for the Court's marked disinterest in the "Framers' intent." 14 Anthony Amsterdam was blunter, but no further from the mainstream, when he concluded in his acclaimed lectures on the Fourth Amendment that "[i] ts language is no help and neither is its history." 15

Within the past decade, though, the academic tide has turned. History, as one leading scholar has noted, "is becoming the dominant subject matter" of Fourth Amendment studies, and of writings on criminal proce-

(1974) (describing Boyd as "a case which has been the subject of repeated citation, discussion, and explanation").

9. See Chandler v. Miller, 520 U.S. 305, 322 (1997); Winston v. Lee, 470 U.S. 753, 758 (1985); United States v. Knotts, 460 U.S. 276, 280 (1983); United States v. Payner, 447 U.S. 727, 733-34 (1980); Whalen v. Roe, 429 U.S. 589, 599 n.25 (1977); Califormia Bankers Ass'n, 416 U.S. at 65; Roe v. Wade, 410 U.S. 113, 152 (1973); Eisenstadt v. Baird, 405 U.S. 438, 454 n.10 (1972); Mapp v. Ohio, 367 U.S. 643, 659 (1961); see also infra note 23 and accompanying text.

10. See Chadwick, 433 U.S. at 8; Schneckloth, 412 U.S. at 222 n.4; United States v. United States Dist. Court, 407 U.S. 297, 316 (1972); Coolidge, 403 U.S. at 471 n.27; Chimel v. California, 395 U.S. 752, 760 (1969); Schmerber v. California, 384 U.S. 757, 769 (1966).

11. See Braswell v. United States, 487 U.S. 99, 105-09 (1988); United States v. Ward, 448 U.S. 242, 253-54 (1980); Andresen v. Maryland, 427 U.S. 463, 471-72 (1976); Fisher v. United States, 425 U.S. 391, 407 (1976); Note, The Life and Times of Boyd v. United States (1886-1976), 76 Mich. L. Rev. 184, 212 (1977).

12. Katz v. United States, 389 U.S. 347, 350 (1967).

13. See United States Dist. Court, 407 U.S. at 316; Stanford v. Texas, 379 U.S. 476, 481-85 (1965); Marcus v. Search Warrant, 367 U.S. 717, 728-29 (1961).

14. Peter Arenella, Fourth Amendment, in Encyclopedia of the American Constitution 223 (Leonard W. Levy et al. eds., Supp. 1 1992).

15. Anthony G. Amsterdam, Perspectives on the Fourth Amendment, 58 Minn. L. Rev. 349, 395 (1974). 
dure more broadly. ${ }^{16}$ Some part of this development must be laid at the feet of Akhil Amar, whose provocative call for returning search-andseizure law to "first principles" 17 has generated its own subgenre of responses and counterresponses. ${ }^{18} \mathrm{~A}$ smaller portion of the credit or blame may be due William Cuddihy, whose doctoral dissertation ${ }^{19}$ Justice O'Connor has rightly praised as "one of the most exhaustive analyses of the original meaning of the Fourth Amendment ever undertaken." Whatever the causes, today much of the academy views history as "crucial to an understanding of the Fourth Amendment," 21 and even a scholar as unsympathetic to Amar's project as Carol Steiker faults Amsterdam's lec-

16. William J. Stuntz, The Uneasy Relationship Between Criminal Procedure and Criminal Justice, 107 Yale L.J. 1, 3 n.l (1997).

17. Akhil Reed Amar, Fourth Amendment First Principles, 107 Harv. L. Rev. 757, 759 (1994) [hereinafter Amar, First Principles].

18. See Akhil Reed Amar, The Fourth Amendment, Boston, and the Writs of Assistance, 30 Suffolk U. L. Rev. 53, 72-75 (1996) [hereinafter Amar, Boston]; Akhil Reed Amar, Terry and Fourth Amendment First Principles, 72 St. John's L. Rev. 1097, 1107-14 (1998); Morgan Cloud, Searching Through History; Searching for History, 63 U. Chi. L. Rev. 1707, 1723-47 (1996); Donald Dripps, Akhil Amar on Criminal Procedure and Constitutional Law: "Here 1 Go Down That Wrong Road Again," 74 N.C. L. Rev. 1559, 1563 (1996); Tracey Maclin, The Complexity of the Fourth Amendment: A Historical Review, 77 B.U. L. Rev. 925, 929 (1997); Tracey Maclin, When the Cure for the Fourth Amendment is Worse Than the Disease, 68 S. Cal. L. Rev. 1, 1-7 (1994); Carol S. Steiker, Second Thoughts About First Principles, 107 Harv. L. Rev. 820, $846-57$ (1994) [hereinafter Steiker, Second Thoughts].

19. William J. Cuddihy, The Fourth Amendment: Origins and Original Meaning, 602-1791 (1990) (unpublished Ph.D. dissertation, Claremont Graduate School) (on file with the Columbia University Law Library).

20. Vernonia Sch. Dist. v. Acton, 515 U.S. 646, 669 (1995) (O'Connor, J., dissenting). Not only "exhaustive," but also "exhausting," Morgan Cloud has aptly added. Cloud, supra note 18, at 1713. Fortunately, several useful summaries exist. The best is William Cuddihy \& B. Carmon Hardy, A Man's House Was Not His Castle: Origins of the Fourth Amendment to the United States Constitution, 37 Wm. \& Mary Q. 371 (1980). Also helpful are Leonard W. Levy, Original Intent and the Framers' Constitution 221-26 (1988), and Cloud, supra note 18, at 1713-31.

For a recent, valuable critique both of Amar's work and of Cuddihy's, and an ambitious new search for "the authentic original meaning" of the Fourth Amendment, see Thomas Y. Davies, Recovering the Original Fourth Amendment, 98 Mich. L. Rev. 547, 556 (1999). Professor Davies contends that "the Framers understood "unreasonable searches and seizures' simply as a pejorative label for the inherent illegality of any searches or seizures that might be made under general warrants." Id. at 551. As will become apparent, I differ with Professor Davies not only on this point, but also regarding the clarity and consistency of common-law rules of search and seizure, and regarding the views of lateeighteenth-century Americans about the common law. See infra notes 133, 188, 248, 289, $296,337,357,441$. Nonetheless we reach some similar conciusions, particularly regarding the hazards of "employ[ing] framing-era doctrines selectively to answer specific modern issues." Davies, supra, at 556.

21. Ronald J. Allen \& Ross M. Rosenberg, The Fourth Amendment and the Limits of Theory: Local Versus General Tbeoretical Knowledge, 72 St. John's L. Rev. 1149, 1169 (1998). 
tures for their "virtual dismissal of the role of text and history in constitutional interpretation."22

So perhaps it is unsurprising that the Supreme Court itself recently has turned back to history for guidance in interpreting the Fourth Amendment. Less predictable, possibly, are the aspects of history the Court now finds pertinent. Justices Bradley, Brandeis, and Frankfurter all focused on particular forms of search and seizure condemned in the years preceding the American Revolution: the general warrants struck down by English courts in the 1760s, and the writs of assistance that provoked widespread opposition in the colonies. They sought to generalize from those controversies to the underlying evils against which the Fourth Amendment took aim. ${ }^{23}$ Both the Court and its commentators have favorably contrasted this strategy with approaches that would limit a constitutional prohibition to "the mischief which gave it birth."24 So it would be odd if the Court now read the Fourth Amendment to prohibit only general warrants and writs of assistance. The Court in fact has not done so, but it has done something that may seem even stranger. It has made the principal criterion for identifying violations of the Fourth Amendment "whether a particular governmental action ... was regarded as an unlawful search or seizure under the common law when the Amendment was framed." 25

Novelty aside, this is a curious reading in at least two respects. First, the Fourth Amendment on its face says nothing about common law, but bans all unreasonable searches and seizures, whether or not they were legal before the Amendment was adopted. Second, the chief proponent of the Court's new understanding of the Fourth Amendment has been Justice Scalia, who is also its most vocal advocate of giving constitutional and statutory provisions their "plain meaning."

My task in this Article is to explain how Justice Scalia and the Court have wound up reading eighteenth-century common law into the Fourth Amendment, to explore the ramifications of the Court's approach, and to appraise its merits. Ultimately, I conclude that the new understanding

22. Carol S. Steiker, Of Cities, Rainforests, and Frogs: A Response to Allen and Rosenberg, 72 St. John's L. Rev. 1203, 1204 (1998).

23. See, e.g., Landynski, supra note 8, at 60-61 (discussing Boyd); James Boyd White, Justice as Translation 149-57 (1990) (discussing Brandeis's dissent in Olmstead); Amsterdam, supra note 15, at 396-97 (discussing Frankfurter's use of history in Fourth Amendment cases). Lawrence Lessig points to Brandeis's "justly famous dissent" in Olmstead as a model for the kind of "translation" that Lessig advocates in constitutional interpretation. Lawrence Lessig, Fidelity in Translation, 71 Tex. L. Rev. 1165, 1239-40 (1993) [hereinafter Lessig, Fidelity in Translation].

24. Olmstead v. United States, 277 U.S. 438, 473 (1928) (Brandeis, J., dissenting) (quoting Weems v. United States, 217 U.S. 349, 373 (1910)); accord Thompson v. Oklahoma, 487 U.S. 815, 822 n.4 (1988); Poe v. Ullman, 367 U.S. 497, 551 (1961) (Harlan, J., dissenting); see White, supra note 23, at 149-59; Lessig, supra note 23, at 1239 .

25. Wyoming v. Houghton, 526 U.S. 295, 299 (1999); accord Florida v. White, 526 U.S. 559, 563 (1999); Wilson v. Arkansas, 514 U.S. 927, 931 (1995). 
has little to recommend it, even to those generally sympathetic with "originalist" interpretations of the Constitution. Neither the text nor the background of the Fourth Amendment suggests it aims merely to codify eighteenth-century rules of search and seizure. Those rules, moreover, were both hazier and less comprehensive than the Court has suggested, and much of the guidance they do provide-by highlighting certain questions and pushing others to the background-is guidance we should hesitate to follow.

The Article has two parts. Part 1 is descriptive. It examines the development and content of the Court's current view of the Fourth Amendment as first and foremost codifying common-law rules of search and seizure-a view 1 will call the new Fourth Amendment originalism. ${ }^{26}$ Justice Scalia's early search-and-seizure opinions took a more conventional approach to the Fourth Amendment, focusing not on eighteenth-century common law, but on the Court's own body of well-established glosses on the Amendment. I discuss in some detail how Justice Scalia gradually rejected that approach in favor of the new Fourth Amendment originalism, and then slowly won the Court over to his new position. The fine points of this story are important for at least two reasons. First, the process through which Justice Scalia grew disenchanted with the Court's conventional mode of Fourth Amendment analysis sheds light on what motivates the new methodology, and on the seriousness with which it deserves to be taken. Second, by illustrating the Court's traditional method of interpreting the Fourth Amendment, Justice Scalia's early search-andseizure opinions help make clear what is distinctive about the new approach, and they will allow us, in Part II, to compare the merits of the two techniques in the hands of the same judge.

Part 1 of the Article also sketches some implications of the new Fourth Amendment originalism: aspects of current doctrine that it threatens and avenues of future doctrinal development it may foreclose. 1 point out, for example, that the rhetoric of the recent search-andseizure cases may make it harder to argue that Fourth Amendment law should do more to protect against racial discrimination or the abusive dissemination of lawfully collected information. The problem is not so much the answers provided by eighteenth-century rules of search and seizure. Those, I will argue in Part 11, are few and far between. The problem rather is the limited range of questions that eighteenth-century judges and commentators asked about searches and seizures. With few exceptions those questions rarely touched on matters of equal treatment; on the contrary, the eighteenth-century law of search and seizure system-

26. I could call it "common Iaw originalism," except that Jane Schacter has recently used that term to describe a very different phenomenon. See Jane S. Schacter, The Confounding Common Law Originalism in Recent Supreme Court Statutory Interpretation: Implications for the Legislative History Debate and Beyond, 5I Stan. L. Rev. I, 2-6 (I998). On the differences between Schacter's "common law originalism" and the new Fourth Amendment originalism, see infra note 424 and accompanying text. 
atically and intentionally protected class privilege. And because eighteenth-century recordkeeping was so rudimentary, the common law had little occasion to worry about how goverument officials used and shared the information they had gathered.

Part II of the Article is evaluative. Drawing in part on extrajudicial writings of Justice Scalia, it considers three possible arguments for the Court's new view of the Fourth Amendment: the text of the Amendment, considered in historical context; the intent of those who drafted and ratified the provision; and the advantages of measuring the constitutionality of searches and seizures by a fixed standard. I argue that in the end none of these arguments is convincing, and that Fourth Amendment law, like constitutional law more generally, should continue to take from common law not a set of substantive rules, but rather a method for reasoned, stepby-step elaboration of what the Constitution commands-a method exemplified, ironically, by Justice Scalia's early search-and-seizure opinions.

I focus in this Article on a particular form of originalism, applied to a particular constitutional provision. At points I draw on work addressing the question of originalism more broadly, and some of what I say may bear on this larger question. But 1 have purposely restricted my scope; the new Fourth Amendment originalism, I try to show, should be unattractive even to those generally sympathetic to originalism. The relationship between the Fourth Amendment and common law has been, and should continue to be, richer and more complex than the Court's recent opinions suggest.

\section{The New Fourth Amendment Originalism}

\section{A. Origins of the New Originalism}

I. First Prelude: Ollman v. Evans. - When Justice Scalia joined the Supreme Court in 1986, few people expected him to overhaul Fourth Amendment law. ${ }^{27}$ Scalia's academic writings had focused on administrative law, and he rarely wrote on criminal procedure during his four years on the United States Court of Appeals for the District of Columbia Circuit. ${ }^{28}$ Prior to his elevation he had published opinions in only two Fourth Amendment cases, neither of them remotely resembling a conventional criminal prosecution, and both turning on questions of justiciability rather than the reasonableness of a search or seizure. ${ }^{29}$ Some

27. Some seasoned Court-watchers, in fact, doubted that Scalia's replacement of Chief Justice Burger would significantly alter any area of constitutional law. See Constitutional Law Conference, 55 U.S.L.W. 2225, 2227, 2230, 2235 (Oct. 28, 1986).

28. See George Kannar, The Constitutional Catechism of Antonin Scalia, 99 Yale L.J. 1297, 1321 (1990); Michael Patrick King, Justice Antonin Scalia: The First Term on the Supreme Court-1986-1987, 20 Rutgers L.J. 1, 6 (1988).

29. See Ramirez de Arellano v. Weinberger, 745 F.2d 1500, 1550 (D.C. Cir. 1984) (en banc) (Scalia, J., dissenting), rev'g 724 F.2d 143 (D.C. Cir. 1983) (Scalia, J.); United Presbyterian Church v. Reagan, 738 F.2d 1375, 1378 (D.C. Cir. 1984). Shortly after taking his seat on the Supreme Court, Scalia published three additional opinions in Fourth 
civil libertarians feared Scalia would prove another law-and-order justice, on the model of Chief Justice Burger, whose retirement created the vacancy Scalia filled, or of Justice Rehnquist, elevated to Chief Justice concurrently with Scalia's appointment. But little concern was voiced that Scalia would take the lead in rewriting search-and-seizure doctrine. ${ }^{30}$

Judge Scalia's record on the court of appeals did provide a clue to the approach he ultimately would take to the Fourth Amendment, but even careful onlookers could be excused for missing it, because it came not in a search-and-seizure case, but in a libel suit, Ollman v. Evans. ${ }^{31}$ Bertell Ollman, a professor of political science at New York University, sued Rowland Evans and Robert Novak for libel after they suggested in their newspaper column that he had used his classroom to indoctrinate students into Marxism and that he had "no status within the profession." 32 The district court granted Evans and Novak summary judgment on the ground that their statements were expressions of opinion and therefore protected by the First Amendment. Sitting en banc, the court of appeals affirmed. Ironically enough, the majority opinion was written by Judge Kenneth Starr, and the principal concurring opinion was by Judge Robert Bork, both of whom later had their own quarrels with the press, although not with Evans and Novak.

Judge Bork's opinion is of particular interest, because it was the main target of Scalia's dissent. Bork recognized that several of the statements Evans and Novak made in their column-particularly the suggestion that Ollman had "no status"-would generally be considered statements of fact, not simply expressions of opinion. ${ }^{33}$ He thought that the statements should nonetheless receive protection under the First Amendment because "in practical impact" they closely resembled expressions of opinion: they were "the kind of hyperbole that must be accepted in the rough and tumble of political argument." 34 Bork acknowledged that the Supreme Court had not yet extended First Amendment protection to statements of this kind. But he argued that First Amendment doctrine must "evolve" to

Amendment cases that had been briefed and argued before the Court of Appeals the previous year. Each concerned not the scope of the Fourth Amendment itself, but rather the scope of qualified immunity for wiretaps ostensibly prompted by national security concerns. See Halperin v. Kissinger, 807 F.2d 180, 183-94 (D.C. Cir. 1986); Smith v. Nixon, 807 F.2d 197, 201-04 (D.C. Cir. 1986); Ellsberg v. Mitchell, 807 F.2d 204, 207 (D.C. Cir. 1986).

30. See Kannar, supra note 28 , at 1321,1324 . Almost no attention was paid to Justice Scalia's views on criminal justice during his two-day confirmation hearing, although one opponent of the nomination drew attention to Scalia's reference, made in passing in a double jeopardy case, to the "public disrepute" brought upon the judiciary by the exclusionary rule. See Nomination of Judge Antonin Scalia: Hearings Before the Senate Comm. on the Judiciary, 99th Cong. 263 (1986) (statement of Audrey Feinberg); United States v. Richardson, 702 F.2d 1079, 1086 (D.C. Cir. 1983) (Scalia, J., dissenting).

31. 750 F.2d 970 (D.C. Cir. 1984) (en banc), cert. denied, 471 U.S. 1127 (1985).

32. ld. at 973 .

33. Id. at 994 (Bork, J., concurring).

34. Id. at 998 . 
ensure that the "freedoms the framers specified are made effective in today's circumstances." 35 Bork explained that

we have a judicial tradition of a continuing evolution of doctrine to serve the central purpose of the first amendment . . . J Judges given stewardship of a constitutional provision-such as the first amendment - whose core is known but whose outer reach and contours are ill-defined, face the never-ending task of discerning the meaning of the provision from one case to the next ... [I] $\mathrm{t}$ is the task of the judge in this generation to discern how the framers' values, defined in the context of the world they knew, apply to the world we know. ${ }^{36}$

By way of analogy, Bork pointed to search-and-seizure doctrine: "The Fourth Amendment was framed by men who did not foresee electronic surveillance. But that does not make it wrong for judges to apply the central value of that amendment to electronic invasions of personal privacy." 37

Bork thus invoked not only the interpretive method of Brandeis's dissent in Olmstead $v$. United States but also the substantive lesson Brandeis drew: that the Fourth Amendment should guard against electronic surveillance as well as more traditional forms of government snooping, because both equally threaten what the Amendment seeks to protect, even though hidden microphones obviously were beyond the contemplation of those who drafted and adopted it. ${ }^{38}$ Similarly, Bork suggested, defamation actions of the kind brougbt by Ollman threatened the values at the heart of the First Amendment. The Framers of that Amendment

gave into our keeping the value of preserving free expression and, in particular, the preservation of political expression .... Perhaps the framers did not envision libel actions as a major threat to that freedom ... . But if, over time, the libel action becomes a threat to the central meaning of the first amendment, why should not judges adapt their doctrines? . . . A judge who refuses to see new threats to an established constitutional value, and hence provides a crabbed interpretation that robs a provision of its full, fair, and reasonable meaning, fails in his judicial duty. ${ }^{39}$

Few more striking tributes can be found to the spirit of Boyd $v$. United States. ${ }^{40}$

35. Id. at 996 .

36. Id. at 995.

37. Id.

38. See Olmstead v. United States, 277 U.S. 438, 472-78 (1928) (Brandeis, J., dissenting).

39. Ollman, 750 F.2d at 996 .

40. 116 U.S. 616 (1886). Rare, too, are more explicit examples of what Lawrence Lessig has praised as "fidelity in translation." Lessig initially seemed uncertain whether to embrace Bork's opinion in Ollman as a methodological model, see Lessig, Fidelity in Translation, supra note 23 , at 1171 n.30, 1261 n.361, but since has been more openly 
But Judge Scalia would have none of it. In a dissent similar in tone to many of his later swipes at fellow conservative justices, Scalia mocked both Bork's "lugubrious description of the plight of the modern political publicist" and his "creative approach" to free-speech law. ${ }^{41}$ Scalia argued "that the identification of 'modern problems' to be remedied is quintessentially legislative rather than judicial business-largely because it is such a subjective judgment." 42 Consequently, "the remedies are to be sought through democratic change rather than through judicial pronouncement that the Constitution now prohibits what it did not prohibit before." 43 Scalia found judges' "cloistered capacity to identify 'modern problems' suspect" and their "ability to provide condign solutions through the rude means of constitutional prohibition . . . nonexistent." 44

Scalia also rejected Bork's analogy to search-and-seizure law: "I am not in need of the concurrence's reminder that the fourth amendment must be applied to modern electronic surveillance . . . The application of existing principles to new phenomena . . . is what I would call not 'evolution' but merely routine elaboration of the law." 45 Nonetheless, Scalia's opinion in Ollman presaged in important ways his later discomfort both with historically guided interpretation of the Constitution in the manner of Bradley, Brandeis, and Frankfurter, and with the modern, ahistoric construction of the Fourth Amendment.

2. Second Prelude: Arizona v. Hicks. - The implications of the views Scalia set forth in Ollman for his approach to the Fourth Amendment took a while to become apparent. Although marked by his characteristic panache, and by his oft-stated preference for clear rules, the search-andseizure opinions Scalia wrote during his first four terms on the Supreme Court appear, in retrospect, fairly conventional. Some familiarity with these early cases will make the novelty of his later opinions more apparent.

The pattern was set in Arizona v. Hicks, Scalia's first Fourth Amendment opinion following his appointment to the Court. ${ }^{46}$ Police officers lawfully entered Hicks's apartment after a bullet was fired through the floor, hitting someone in the apartment below. They found some stereo equipment that they suspected had been stolen, and they confirmed their suspicions by lifting a turntable to read the serial number and running the number through a database. At issue was whether the police acted constitutionally when they lifted the turntable. Writing for the Court, Scalia treated the case as calling for a straightforward application of ex-

admiring, see Lawrence Lessig, Fidelity and Constraint, 65 Fordham L. Rev. 1365, 1419-20 (1997).

41. Ollman, 750 F.2d at 1036, 1038 (Scalia, J., dissenting).

42. 1d. at 1038 .

43. ld.

44. Id. at 1039 .

45. Id. at 1038 n.2.

46. 480 U.S. 321 (1987). 
isting doctrine. Lifting the turntable was a "search," because it "produce[d] a new invasion of respondent's privacy unjustified by the exigent circumstance that validated the entry." 47 If the police had possessed probable cause to believe the turntable was stolen when they first saw it, they could have seized it pursuant to the "plain view" doctrine, and a fortiori could have carried out the lesser intrusion of lifting it to read the serial number. ${ }^{48}$ But since the officers lacked probable cause until they obtained the serial number, the plain view doctrine did not apply, and the search was illegal. ${ }^{49}$

In a dissent joined by Justice Powell and Chief Justice Rehnquist, Justice O'Connor argued that a "cursory inspection" of an item in plain view should require not probable cause, but only "reasonable, articulable suspicion" that the item is evidence of a crime ${ }^{50}$ She borrowed this standard, of course, from the doctrine of Terry $v$. Ohio, ${ }^{51}$ which allows the police to detain a suspect for brief questioning based on "reasonable, articulable suspicion" of criminality, and to frisk a detained individual for weapons based on "reasonable, articulable suspicion" that the person is armed and dangerous. ${ }^{52}$ Terry had arrived at this rule by explicitly balancing law enforcement needs against privacy interests, and Justice O'Connor had conducted a similar balancing when she led the Court in extending Terry to permit cursory searches for weapons in lawfully stopped automobiles that the police reasonably believe may contain weapons. ${ }^{53}$ ln Hicks she argued for another extension, finding the "minimal additional invasion of privacy" outweighed by "rather major gains in law enforcement." 54

Justice Scalia rejected this innovation on the ground that it would needlessly complicate the law. He was "unwilling to send police and judges into a new thicket of Fourth Amendment law, to seek a creature of uncertain description that is neither a 'plain view' inspection nor yet a "full-blown search," " particularly when "[n]othing in the prior opinions of this Court support[ed] such a distinction." 55 He conceded that O'Connor's approach might help the police catch more criminals, but he chose "to adhere to the textual and traditional standard of probable cause." 56

Two features of Justice Scalia's opinion for the Court in Hicks are worth noting. First, consistent with his dissent in Ollman, he favors rules

47. Id. at 325 .

48. See id. at 326.

49. See id. at 327-28.

50. Id. at 335 (O'Connor, J., dissenting).

51. 392 U.S. I (1968). (I979).

52. United States v. PIace, 462 U.S. 696, 702 (1983); Brown v. Texas, 443 U.S. 47, 51

53. See Michigan v. Long, 463 U.S. 1032, I049 (1983).

54. 480 U.S. at 338 (O'Connor, J., dissenting).

55. 1d. at 328-29 (opinion of the Court).

56. Id. at 329 . 
that are both clear and stable. Second, he looks for those rules not just in the text of the Fourth Amendment, but also in "tradition"-that is to say, in past decisions of the Court. The text of the Fourth Amendment requires probable cause only for warrants. The Court, though, has long read the "reasonableness" clause of the Amendment to impose a general requirement of probable cause on all searches, with or without warrants-or at least on all searches of homes. This is the "tradition" to which Justice Scalia chooses to adhere in Hicks. There is perhaps a hint in Hicks that Scalia might not find all parts of the tradition equally worthy of respect; he says nothing at all about Terry, and the omission could be taken as pointed. But the hint, if there, is faint.

Justice Scalia's other early Fourth Amendment opinions generally resemble Hicks in these respects. He repeatedly argues for doctrinal simplicity and predictability, but he seeks that simplicity and predictability in past decisions of the Supreme Court giving content to the constitutional prohibition of "unreasonable searches and seizures." Thus, he concludes that the police need a warrant to search someone's personal office because "we decided as much many years ago."57 A probationer's home may be searched without a warrant or probable cause, not under "a new principle of law," but rather pursuant to the established rule-recently established but established nonetheless - that these safeguards may be disregarded when "special needs, beyond the normal need for law enforcement, make the warrant and probable-cause requirement impracticable." 58 A search pursuant to consent is constitutionally reasonable when the officer reasonably but mistakenly believes the person giving consent has authority over the property, because past decisions suggest that reasonableness generally depends on the information available to the officer. ${ }^{59}$ A "seizure" occurs when a suspect fleeing in a car crashes into a roadblock erected to stop him, even if the police wanted him to stop voluntarily - not only because the natural meaning of "seizure" encompasses any situation in which a person is "stopped by the very instrumentality set in motion or put in place in order to achieve that result," 60 but also because that reading was reflected in an earlier decision of the Court, ${ }^{61}$ and accords with the focus of the Fourth Amendment law on "misuse of power." 62

None of these opinions so much as mentions the common law of search and seizure, let alone suggests that the common law is more important than the Court's own "tradition" in giving content to the Fourth

57. O'Connor v. Ortega, 480 U.S. 709, 730 (1987) (Scalia, J., concurring) (discussing Mancusi v. DeForte, 392 U.S. 364 (1968)).

58. Griffin v. Wisconsin, 483 U.S. 868, 873 (1987) (quoting New Jersey v. T.L.O., 469

U.S. 325, 351 (1985) (Blackmun, J., concurring)).

59. See Illinois v. Rodriguez, 497 U.S. 177, 185-86 (1990).

60. Brower v. County of Inyo, 489 U.S. 593, 599 (1989).

61. See id. at 597-98 (discussing Hester v. United States, 265 U.S. 57 (1924)).

62. Id. at 596 (quoting Byars v. United States, 273 U.S. 28, 33 (1927)). 
Amendment. Justice Scalia seemed comfortable even with that part of the Court's tradition that called for open-ended balancing to assess the reasonableness of some searches and seizures. Dissenting from a decision upholding mandatory drug testing of Customs Service employees, he reasoned that " $[\mathrm{w}]$ hile there are some absolutes in Fourth Amendment law, as soon as those have been left behind and the question comes down to whether a particular search has been 'reasonable,' the answer depends largely upon the social necessity that prompts the search"-a necessity that he argued was marginal, and entirely symbolic, in the case of the Customs Service drug testing. ${ }^{63}$

Despite Justice Scalia's apparent comfort in these early opinions with received interpretations of the Fourth Amendment, the opinions contain the seeds of his ultimate dissatisfaction with those interpretations. For in truth the Court's past Fourth Amendment decisions were a poor place to look for clarity and stability. Much can be said for the Court's search-andseizure jurisprudence, but few observers, on or off the Court, have praised it for consistency. On the contrary, the term most often used to describe Fourth Amendment law is "mess." 64 Perhaps it was only a matter of time before Justice Scalia's desire for clarity and stability would come into conflict with his adherence to Fourth Amendment tradition.

3. Third Prelude: Brower v. County of Inyo. - If Justice Scalia's early opinions set the stage for his eventual disenchantment with the modern, ahistoric approach to the Fourth Amendment, they also illustrated, more modestly, the ambiguities that can surround an appeal to history. In this way they foreshadowed certain conceptual difficulties later made more pressing by the new Fourth Amendment originalism.

In the course of his opinion in the roadblock case, Brower $v$. County of Inyo, Justice Scalia distinguished a set of cases deemed analogous by the court below: cases involving fleeing defendants who unexpectedly crashed into preexisting obstacles. Those cases were different, Scalia reasoned, because they involved "accidental effects of otherwise lawful government conduct," whereas the Fourth Amendment was aimed at intentional intrusions, such as those licensed by general warrants and writs of assistance. ${ }^{65}$ To support his characterization of writs of assistance as "the principal grievance against which the Fourth Amendment was di-

63. National Treasury Employees Union v. Von Raab, 489 U.S. 656, 681, 686-87 (1989) (Scalia, J., dissenting).

64. See Allen \& Rosenberg, supra note 21, at 1149; Amar, First Principles, supra note 17, at 761; Amsterdam, supra note 15, at 349; Roger B. Dworkin, Fact Style Adjudication and the Fourth Amendment: The Limits of Lawyering, 48 Ind. L.J. 329, 329 (1973); Erik G. Luna, Sovereignty and Suspicion, 48 Duke L.J. 787, 788 (1999); Silas J. Wasserstrom \& Louis Michael Seidman, The Fourth Amendment as Constitutional Theory, 77 Geo. L.J. 19, 20 (1988); see also Chapman v. United States, 365 U.S. 61 0, 618 (1961) (Frankfurter, J., concurring) ("The course of true law pertaining to searches and seizures . . has not- to put it mildly-run smooth.").

65. Brower, 489 U.S. at 596. 
rected,"66 Scalia cited Thomas Cooley's nineteenth-century treatise on the Constitution, ${ }^{67}$ and that preeminent fixture of Fourth Amendment tradition, Boyd $v$. United States. ${ }^{68}$

There is an oddity here, and it recurs with some frequency in Justice Scalia's later search-and-seizure opinions. For an understanding of events in the eighteenth century, Justice Scalia relies in Brower on nineteenth-century sources-and nineteenth-century lawyers, no less. The history in Boyd, in particular, has long been thought unreliable. Wigmore called it "fallacious," 69 an assessment repeatedly acknowledged by the justices and repeatedly echoed by later scholars, including a scholar whose work on the subject Scalia cites for a separate point. ${ }^{70}$ No one really takes Justice Bradley seriously as a historian anymore-nor Thomas Cooley, for that matter. ${ }^{71}$ So why does Scalia turn to them for his history?

Assume for the moment that we have here something more than rank antiquarianism. Assume that Scalia does not value the old simply because it is old, or because it lends an appearance of erudition. Two other explanations suggest themselves.

The first is a variety of intellectual nostalgia: a sense that older writers knew some things-for example, the true nature of events in the eighteenth century-better than those who came later. Now, it is possible, of course, that nineteenth-century writers really did understand the eighteenth century better than we do now, precisely because they were closer to it. But that is not the usual premise of intellectual history, and it is not a proposition often articulated, let alone defended, in Supreme Court opinions. 1t certainly is neither articulated nor defended by Justice Scalia in Brower. That is why 1 use the term "nostalgia": I mean to suggest

66. Id.

67. See Thomas M. Cooley, A Treatise on the Constitutional Limitations Which Rest Upon the Legislative Power of the States of the American Union 301-02 (I868).

68. 116 U.S. 6 I 6 (1886).

69. 8 John Henry Wigmore, Evidence in Trials at Common Law $\$ 2184 a$, at 32 (John T. McNaughton ed., rev. ed. 196I); see also id. $\$ 2264$, at 381-84 n.4. (rejecting as "fallacy" Justice Bradley's claim of an "intimate relation" between the Fourth and Fifth Amendments).

70. See Schmerber v. California, 384 U.S. 757, 776 (1966) (Black, J., dissenting); Abel v. United States, 362 U.S. 217, 255 n.5 (I960) (Brennan, J., dissenting); Frank v. Maryland, 359 U.S. 360,365 n.4 (I959); Landynski, supra note 8, at 58; Telford Taylor, Two Studies in Constitutional Interpretation 60-64 (1969); Amar, First Principles, supra note 17, at 787-90. In Brower Scalia cited Professor Taylor's work for the tangential proposition that the controversy over general warrants in the 1760 s produced "the first and only major litigation in the English courts in the field of search and seizure." 489 U.S. at 596 (quoting Taylor, supra, at 26 ).

71. There is further irony in Justice Scalia's invocation of Cooley. Particularly in his later writings, Cooley emphasized the evolutionary, adaptive nature of common law-a view in some tension with the static understanding of common law reflected in the new Fourth Amendment originalism. See Jeff Sklansky, Corporate Property and Social Psychology: Thomas M. Cooley, Charles H. Cooley, and the Ideological Origins of the Social Self, 76 Radical Hist. Rev. 90, 96-97 (2000); see infra text accompanying notes $336-419$. 
a kind of romantic invocation of lost wisdom. Nostalgia of this sort is nothing new, of course. It was a signal feature of the once widespread understanding of the common law as ancient Saxon custom, predating and uncorrupted by the Conquest-an understanding that pervaded Edward Coke's seventeenth-century Institutes, ${ }^{72}$ and found strong echoes in the rhetoric of Revolutionary America. ${ }^{73}$

The second possibility is that Justice Scalia recognizes Cooley and Bradley as authorities not on how things actually happened in the eighteenth century, but on the significance that "tradition" has come to attach to those events. This, too, is a notion with an impressive pedigree. It is almost commonplace to defend Justice Bradley's opinion in Boyd not as historical scholarship, but as an exercise of legal creativity. ${ }^{74}$ Coke's historical fictions have been described in similar terms, ${ }^{75}$ as have the historical distortions in James Otis's famous argument against the writs of assistance. ${ }^{76}$

Neither of these explanations, though, is without serious difficulty. The first reflects a romanticism so misty-eyed that, when made explicit, it is unlikely to appeal to present-day jurists-least of all, perhaps, one as self-consciously iconoclastic as Scalia. The second, although not so conspicuously irrational, produces exactly the kind of evolving Constitution that Judge Scalia attacked as illegitimate in Ollman $v$. Evans. This dilemma, the choice between the dreamy and the undemocratic, lurked far in the background in Brower $v$. County of Inyo. But it prefigured a central difficulty with the new Fourth Amendment originalism, which, as we will see, flirts uncomfortably both with antiquarianism and with intellectual nostalgia.

72. See J.G.A. Pocock, The Ancient Constitution and the Feudal Law 36 (1957); Harold J. Berman, The Origins of Historical Jurisprudence: Coke, Selden, Hale, 103 Yale L.J. 1651, 1687-89 (1994).

73. On Coke's influence on the American Revolutionaries, see, e.g., Edward S. Corwin, The "Higher Law" Background of American Constitutional Law 72-77 (1955); Charles F. Mullett, Coke and the American Revolution, 12 Economica 457 (1932). On the broader theme of lost virtue in Revolutionary rhetoric, see, e.g., Bernard Bailyn, The Ideological Origins of the American Revolution 25-26 (1967); Julian S. Waterman, Thomas Jefferson and Blackstone's Commentaries, 27 Ill. L. Rev. 629, 640-42 (1933). For the importance of this theme to the seventeenth-century English radicals to whom the American Revolutionaries frequently turned for inspiration, see, e.g., 2 Algernon Sidney, Discourses Concerning Government 308 (New York, Deare and Andrews 1805); Caroline Robbins, Algernon Sidney's Discourses Concerning Government: Textbook of Revolution, 4 Wm. \& Mary Q. 267 (1947).

74. For an influential example, see Landynski, supra note 8, at 60-61.

75. See H. Trevor Colbourn, The Lamp of Experience: Whig History and the Intellectual Origins of the American Revolution 8 (1965); James R. Stoner, Jr., Common Law and Liberal Theory: Coke, Hobbes, and the Origins of American Constitutionalism 62-68 (1992); William Holdsworth, Sir Edward Coke, 5 Cambridge L.J. 332, 340-42 (1935); Cuddihy, supra note 19, at 215-33.

76. See Levy, supra note 20, at 227; Cuddihy, supra note 19, at 788-89. 
4. The New Originalism in Embryo. - The conflict between the twin commitments of Justice Scalia's early Fourth Amendment jurisprudence-the commitment to clarity and stability, and the commitment to "tradition"-became manifest in three cases decided in the spring of 1991.

The first sign of trouble was California $v$. Hodari $D$., in which the Court held that a suspect running from the police was not "seized" until he was actually captured. ${ }^{77}$ Writing for the Court, Justice Scalia reasoned that the ordinary meaning of the term "seizure" does not include chasing someone: "That is no seizure."78 To buttress his argument, and to show that the meaning of the term has not changed in this respect since the adoption of the Fourth Amendment, he cited a pair of nineteenth-century dictionaries and several common-law decisions from the same period. ${ }^{79}$ In dissent, Justice Stevens accused the Court of rejecting modern Fourth Amendment doctrine in favor of "ancient common-law precept."80 But Justice Scalia denied taking that step. He had consulted common law, he explained, not to gauge the scope of the Fourth Amendment, but simply to judge the meaning of "seizure." Therefore it was "irrelevant" whether unsuccessful efforts to take someone into custody were punishable at common law: "The common law may have made an attempted seizure unlawful in certain circumstances; but it made many things unlawful, very few of which were elevated to constitutional proscriptions." 81

Justice Scalia's demurral had a good deal of merit: the chief interpretive tool in Hodari $D$. was plain meaning, not common law. But the concerns raised by Justice Stevens were not groundless. In arguing for the Court that "very few" common-law rules "were elevated to constitutional proscriptions," Scalia could be taken to have suggested that some common-law rules were so elevated, and by implication that the measure of the Fourth Amendment might ultimately be not all common-law rules, but certain common-law rules-the ones pertaining to searches and seizures.

If that reading seems strained, it is nonetheless the one Justice Scalia himself gave to Hodari $D$. a few weeks later, when the Court decided County of Riverside v. McLaughlin. ${ }^{82}$ At issue in that case was the meaning of the Court's holding sixteen years earlier in Gerstein $v$. Pugh that a warrantless arrest is unreasonable under the Fourth Amendment absent a prompt judicial determination of probable cause. ${ }^{83}$ Writing for the Court in McLaughlin, Justice O'Connor reasoned that delays longer than

\footnotetext{
77. 499 U.S. 621 (1991).

78. Id. at 626 .

79. See id. at 624 .

80. Id. at 647 (Stevens, J., dissenting); see also id. at $632-37,646$ n.18.

81. Id. at 626 n. 2 (opinion of the Court).

82. 500 U.S. 44 (1991).

83. 420 U.S. $103,114(1975)$.
} 
forty-eight hours generally are unlawful, but that shorter delays are presumptively reasonable, even if they are justified in part by the desire to combine the probable cause hearing with other pretrial proceedings. ${ }^{84}$ Justice Scalia dissented. Citing Hodari $D$., he argued that "the Fourth Amendment's prohibition of 'unreasonable seizures,' insofar as it applies to seizure of the person, preserves for our citizens the traditional protections against unlawful arrest afforded by the common law." 85 Among the most important of those protections, he contended, was that a suspect arrested without warrant be taken before a magistrate as soon as reasonably possible, regardless of whether it would be administratively convenient to delay the appearance. ${ }^{86}$

Scalia's dissent in McLaughlin stressed the dependability of the common law as a measure of Fourth Amendment protections: far more reliably than the unguided instincts of the judiciary, it offered a safe harbor against political winds unfavorable to civil liberties. He conceded the need to balance law enforcement interests against privacy concerns in addressing "novel" issues of reasonableness under the Fourth Amendment. But there was no call for such balancing, he argued, "in resolving those questions on which a clear answer already existed in 1791 and has been generally adhered to by the traditions of our society ever since." 87 For those questions, "the 'balance' has already been struck . . . and it is the function of the Bill of Rights to preserve that judgement"-against changing views of the justices no less than against changing views of the President and Congress. ${ }^{88}$ Scalia quoted Justice Story's remark-in the only paragraph on search and seizure in Story's multivolume treatisethat the Fourth Amendment "is little more than the affirmance of a great constitutional doctrine of the common law." 89 But as yet Scalia argued only that the Amendment "should not become less than that."90 The common law of arrest, he suggested, should operate as a floor on Fourth Amendment protections.

Later the same month, concurring in the judgment in California $v$. Acevedo, Scalia went further: he argued that at least in some cases the common law should provide a ceiling as well as a floor, and that the common law could remedy not only the instability of search-and-seizure doctrine, but also its confusion and inconsistency. ${ }^{91}$ Acevedo concerned the

84. See McLaughlin, 500 U.S. at 56-57.

85. Id. at 60 (Scalia, J., dissenting).

86. See id. at 61,66 .

87. Id. at 60.

88. Id.; see also id. at 66 ("It was the purpose of the Fourth Amendment to put this matter beyond time, place, and judicial predilection, incorporating the traditional common-law guarantees against unlawful arrest.").

89. Id. at 71 (quoting 3 Joseph Story, Commentaries on the Constitution of the United States 748 (1833)). For further discussion of this remark, see infra text accompanying notes $280-290$.

90. McLaughlin, 500 U.S. at 71.

91. 500 U.S. 565, 581-85 (1991) (Scalia, J., concurring). 
legality of a warrantless search of a package carried in a car, based on probable cause to believe the package contained contraband. ${ }^{92}$ Past decisions had painted the Court into something of a corner on this question. The Court had held that cars could be searched pursuant to probable cause without a warrant, partly because their mobility would often make getting a warrant impractical,9.9 and partly because the visibility and broad regulation of automobiles diminishes a motorist's reasonable expectation of privacy. ${ }^{94}$ Portable containers had been treated differently: although they resembled vehicles in mobility, they lacked the diminished expectation of privacy, so the Court had ruled that they generally could not be searched without a warrant. ${ }^{95}$ What about containers in cars? For a while, the Court had tried with increasing difficulty to distinguish between searches of cars, containers and all, ${ }^{96}$ and searches of containers that happened to be inside cars. ${ }^{97}$ In Acevedo the justices gave up the struggle and ruled that searcbes of packages in cars, so long as they were based on probable cause, never required a warrant-even though a search of the package before it was placed in the car would require a warrant. 98

Scalia concurred in the judgment but wrote separately to make a broader point. The Court's decision, in his view, carried forward "an inconsistent jurisprudence." 99 Citing principally his own opinions in Hodari D. and McLaughlin, Scalia proposed "the path out of this confusion should be sought by returning to the first principle that the "reasonableness' requirement of the Fourth Amendment affords the protection that the common law afforded." 100 In particular, he argued that the common law did not generally require warrants: he adopted Akhil Amar's position that eighteenth-century warrants served not as a prerequisite for search or seizure but rather to immunize officers against civil liability for conduct that juries later deemed "unreasonable."101

92. See id. at 565 (opinion of the Court).

93. See Chambers v. Maroney, 399 U.S. 42, 48 (1970); Carroll v. United States, 267 U.S. 132, 153 (1925).

94. See United States v. Chadwick, 433 U.S. 1, 12-13 (1977).

95. See id, at 13-16.

96. See United States v. Ross, 456 U.S. 798, 825 (1982).

97. See Arkansas v. Sanders, 442 U.S. 753, 763-66 (1979).

98. See California v. Acevedo, 500 U.S. 565, 580 (1991).

99. Id. at 583 (Scalia, J., concurring).

100. Id. Scalia also cited People v. Chiagles, in which Judge Cardozo, himself citing Boyd, reasoned that New York's statutory analog to the Fourth Amendment "express[ed] the principle that English law received" during the litigation over general warrants in the 1760 s, and that therefore " $[t]$ he immunity is not from all search and seizure, but from search and seizure unreasonable in the light of common-law traditions." 142 N.E. 583, 583 (N.Y. 1923). On the import of this argument, see infra note 285 and accompanying text.

10I. Acevedo, 500 U.S. at 581-82 (citing Akhil Reed Amar, The Bill of Rights as a Constitution, 100 Yale L.J. 1131, 1178-80 (1991)). Amar later expanded on the argument in Amar, First Principles, supra note 17, at 771-81. 
Scalia thus advanced in Acevedo the proposition he had hinted at in Hodari $D$. and only partially mooted in McLaughlin - that eighteenth-century common law should be the measure of Fourth Amendment protection. But as yet he had only his own vote. And his commitment to common law as the measure of constitutional reasonableness remained somewhat hedged. He explained that he joined the judgment of the Court because he thought it adhered more closely than the dissent "to the text and tradition of the Fourth Amendment."102 And he acknowledged that "changed legal circumstances"-for example, the limitations the Court has imposed on the liability of officers for actions taken in good faith-"may make a warrant indispensable to reasonableness where it once was not." 103 He urged rejection of the warrant requirement not just because it appeared to lack "any basis in common law," but also because it "confuses rather than facilitates" the development of sensible doctrine. ${ }^{104}$ lronically, his thesis was to grow less rather than more qualified before the Court embraced it.

5. The Birth of the New Originalism. - Justice Scalia's commitment to eighteenth-century common law as the measure of Fourth Amendment protection strengthened in his next search-and-seizure opinion, his concurrence in Minnesota $v$. Dickerson. ${ }^{105}$ The defendant in Dickerson had been stopped for brief questioning and frisked for weapons under the rule of Terry $v$. Ohio. ${ }^{106}$ After satisfying himself that the defendant was unarmed, the officer nonetheless continued his tactile inspection of the defendant's clothing, eventually recovering a lump of crack cocaine. Reasoning much as it had in Arizona $v$. Hicks, ${ }^{107}$ the Court found the additional search unlawful without a warrant. Justice Scalia joined the Court's opinion but wrote separately to voice reservations about even the frisk permitted by Terry.

The purpose of the Fourth Amendment, Scalia declared, was "to preserve that degree of respect for the privacy of persons and the inviolability of their property that existed when the provision was adopted." $108 \mathrm{He}$ therefore had little use for the analysis in Terry, because the Court had "made no serious attempt to determine compliance with traditional standards," but instead simply had asked what "was 'reasonable' by current estimations"109-applying what Scalia derided as "the original-meaningis-irrelevant, good-policy-is-constitutional-law school of jurisprudence."110 Still, Scalia thought that brief investigatory detentions of the kind approved in Terry probably were consistent with the common law, because

102. Acevedo, 500 U.S. at 581 (emphasis added).

103. 500 U.S. at 583-84.

104. 1 d. at 584 .

105. 508 U.S. $366,379-83$ (1993) (Scalia, J., concurring).

106. 392 U.S. 1 (1968); see supra text accompanying notes 51-52.

107. 480 U.S. $321,321-22$ (1986); see supra text accompanying notes 46-56.

108. Dickerson, 508 U.S. at 380 .

109. 1d.

110. 1d. at 382. 
"it had long been considered reasonable to detain suspicious persons for the purpose of demanding that they give an account of themselves."111 He was less sure about frisks for weapons, because when "the detention did not rise to the level of a full-blown arrest (and was not supported by the degree of cause needful for that purpose), there appears to be no clear support at common law for physically searching the suspect."112 What is more, Scalia "frankly doubt[ed] ... whether the fiercely proud men who adopted our Fourth Amendment would have allowed themselves to be subjected, on mere suspicion of being armed and dangerous, to such indignity"-although he also noted that subsequent developments in firearms technology may have altered what is "reasonable."113

As in McLaughlin and Acevedo, Scalia wrote only for himself in Dickerson. And even Professor Amar, who applauded Justice Scalia's opinion in Acevedo, was given pause by the concurrence in Dickerson, which Amar thougbt flirted with a "'frozen in amber' approach to Fourth Amendment reasonableness." 114 Within two years, however, there were signs of sympathy elsewhere on the Court for Scalia's interpretive method. The evidence came in Wilson v. Arkansas, in which Justice Thomas wrote for a unanimous court. ${ }^{115}$ The holding was almost humdrum: a search of a home can be rendered "unreasonable" for purposes of the Fourth Amendment if the officers fail to knock and to announce their presence before entering-unless, under the circumstances, it is reasonable to dispense with the warning. ${ }^{116}$ What was noteworthy about the opinion was its reasoning. To support the Court's conclusion that "the reasonableness of a search of a dwelling may depend in part on whether law enforcement officers announced their presence and authority prior to entering," Justice Thomas reviewed common-law decisions dating from the early seventeenth century up through the 1800s. ${ }^{117}$ Ignoring Terry and Katzindeed, ignoring almost all search-and-seizure decisions from the second half of the twentieth century-Justice Thomas suggested that in determining the scope of the Fourth Amendment "we have looked to the traditional protections against unreasonable searches and seizures afforded by the common law at the time of the framing." 118 To be sure, "the underlying command of the Fourth Amendment is always that searches and

111. Id. at 380. Scalia found particularly persuasive on this point "the so-called nightwalker statutes, and their common-law antecedents." Id. For discussion of these authorities, see infra notes $404-407$ and accompanying text.

112. Id. at 381 .

113. Id. at $381-82$.

114. Amar, First Principles, supra note 17 , at 818 \& n. 230 .

115. 514 U.S. 927 (1995). This was Justice Thomas's first opinion for the Court in a Fourth Amendmient case. I have written previously about the case, and have made some of the same points about it that I make here, in David A. Sklansky, Traffic Stops, Minority Motorists, and the Future of the Fourth Amendment, 1997 Sup. Ct. Rev. 271, 303-07.

116. See 514 U.S. at $934-36$.

117. Id. at $931-36$.

118. Id. at 931 . 
seizures be reasonable," 119 but "our effort to give content to this term may be guided by the meaning ascribed to it by the Framers of the Amendment." 120 Remarkably, no member of the Court objected to the importance Justice Thomas gave common law in assessing the constitutionality of searches and seizures.

Justice Scalia continued to lay the groundwork for a more thoroughgoing rejection of the ahistoric approach to the Fourth Amendment exemplified by Terry-exactly the development Justice Stevens had feared in Hodari D. ${ }^{121}$ Writing for the Court in Vernonia School District 47J v. Acton, Justice Scalia upheld mandatory drug tests for student athletes based on an open-ended balancing of government interests against privacy concerns, but only because "there was no clear practice, either approving or disapproving the type of search at issue, at the time the constitutional provision was enacted." 122 He said not a word about the common law when holding for a unanimous Court in Whren v. United States that an officer's subjective intent is irrelevant to the lawfulness of a traffic stop. ${ }^{123}$ But he returned with gusto to the theme when he concurred in Minnesota v. Carter. ${ }^{124}$ The Court held in Carter that the defendants could not complain about the search of the apartment where they were caught bagging cocaine, because they were visiting the apartment briefly for a business transaction, and therefore had no "reasonable expectation of privacy" there. ${ }^{125}$ Justice Scalia wrote separately to complain that the "reasonable expectation of privacy" test, derived from Katz, lacked any "plausible foundation in the text of the Fourth Amendment," and was "self-indulgent" to boot: "unsurprisingly, those "actual (subjective) expectation[s] of privacy' 'that society is prepared to recognize as "reasonable"' . . bear an uncanny resemblance to those expectations of privacy that this Court considers reasonable." 126 He thought the keys to the case lay in the constitutional text, which could sensibly be read only to protect a suspect against unreasonable searches or seizures of "his own person, house, papers, and effects," and in "the English and early American law of arrest and trespass that underlay the Fourth Amendment."127 That law, Scalia argued, made "every man's house ... his own castle," but "not the castle of another man." 128

119. Id. (quoting New Jersey v. T.L.O., 469 U.S. 325, 337 (1985)).

120. Id. at 931.

121. See supra note 80 and accompanying text.

122. 515 U.S. $646,652-53 \&$ n. 1 (1995).

123. 517 U.S. 806, 806-07 (1996). For a discussion of Whren, see Sklansky, supra note 115 , at $277-79,284-91,309-16$.

124. 525 U.S. $83,91-99$ (1998) (Scalia, J., concurring).

125. Id. at $88-91$.

126. Id. at 97 (quoting Katz v. United States, 389 U.S. 347, 361 (1967)).

127. Id. at 92,94 .

128. Id. at 94 (quoting Johnson v. Leigh, 128 Eng. Rep. 1029, 1030 (C.P. 1815)). 
The full Court had hinted at sympathy for Scalia's new Fourth Amendment originalism in Wilson $v$. Arkansas, ${ }^{129}$ and finally embraced it in Wyoming $v$. Houghton. ${ }^{130}$ The question in Houghton was whether a warrantless search of an automobile based on probable cause could include a search of a passenger's purse; the Court ruled that it could. ${ }^{131}$ That result followed easily enough from Acevedo, but Justice Scalia, writing for a majority of six, took the opportunity to sweep more broadly. In applying the Fourth Amendment, he explained, the Court asks first whether the challenged conduct "was regarded as an unlawful search or seizure under the common law when the Amendment was framed."132 Only if "that inquiry yields no answer" will the Court assess the search or seizure "under traditional standards of reasonableness," balancing the intrusion on privacy against the promotion of legitimate government interests. ${ }^{133}$ This was a good deal more emphatic than the suggestion in Wilson $v$. Arkansas that eighteenth-century understandings "may" give content to the Fourth Amendment, ${ }^{134}$ and it drew an objection from Justice Stevens: "To my knowledge, we have never restricted ourselves to a two-step Fourth Amendment approach wherein the privacy and governmental interests at stake must be considered only if 18th-century common law "yields no answer." 135 But only Justice Souter and Justice Ginsburg joined his dissent. ${ }^{136}$

Strictly speaking, no "18th-century common law" was found applicable by the Court in Houghton. Instead the majority relied on federal legislation in the late-eighteenth century authorizing warrantless inspections of ships by customs officers with probable cause to suspect the presence of contraband. ${ }^{137}$ The Court had cited this same legislation when first authorizing warrantless searches of automobiles based on probable cause, ${ }^{138}$ and later when extending that authorization to include containers found in automobiles. ${ }^{139}$ As in those earlier decisions, the majority in Houghton inferred from the Founding-era legislation that "the Framers" would have thought the challenged search "reasonable." 140

129. 514 U.S. 927 (1995).

130. 526 U.S. 295 (1999).

131. See id. at 307 .

132. Id. at 299 .

133. Id. at 299-300. Professor Davies thus errs in suggesting that Justice Scalia views both the Fourth Amendment and eighteenth-century common law as imposing only a generalized requirement of reasonableness "based on the totality of the circumstances." Davies, supra note 20 , at 550 n.2, $736 \&$ n.539.

134. 5 I 4 U.S. at 93 I.

135. Houghton, 526 U.S. at 311 n.3 (Stevens, J., dissenting).

136. Justice Breyer joined the Court's opinion "with the understanding that history is meant to inform, but not automatically to determine, the answer to a Fourth Amendment question." Id. at 307 (Breyer, J., concurring).

137. See id. at 300 (opinion of the Court).

138. See Carroll v. United States, 267 U.S. I32, 150-51 (1925).

139. See United States v. Ross, 456 U.S. 798, 805-06 (1982).

I40. Houghton, 526 U.S. at 300 . 
In the weeks following Houghton, the Court twice reaffirmed its commitment to the interpretive method announced in that case. Writing for a majority of seven in Florida $v$. White, Justice Thomas again invoked the 1790 s legislation, this time to uphold warrantless seizures of automobiles based on probable cause to believe they are forfeitable as contraband, and he reiterated that "[i]n deciding whether a challenged governmental action violates the [Fourth] Amendment, we have taken care to inquire whether the action was regarded as an unlawful search and seizure when the Amendment was framed." 141 The justices made the same point implicitly in Wilson v. Layne, when they read the Fourth Amendment to forbid as unreasonable most media "ride-alongs" on arrests in private homes. ${ }^{142}$ Writing on this point for a unanimous Court, Chief Justice Rehnquist found it helpful to begin his analysis with platitudes from William Blackstone's Commentaries about the sanctity of the home, and with the 1604 decision in Semayne's Case, the source of the maxim that "the house of every one is to him as his castle and fortress." 143 Even when no pre-enactment authorities were remotely on point, the Court suggested, the common law remained the ultimate touchstone of Fourth Amendment reasonableness. ${ }^{144}$

141. 526 U.S. 559, 563 (1999). Justice Stevens dissented, joined only by Justice Ginsburg. See id. at 567 (Stevens, J., dissenting).

142. 526 U.S. 603, 604 (1999).

143. Id. at 609-10 (quoting 4 William Blackstone, Commentaries *223, and Semayne's Case, 77 Eng. Rep. 194 (K.B. 1604)). Justice Stevens dissented only from a later portion of the Court's opinion, which found the officers entitled to qualified immunity because the Fourth Amendment ban on media ride-alongs had not been "clearly established." Id. at 618-19. And by this point even Justice Stevens fought on the terrain of the new Fourth Amendment originalism: he argued that finding media ride-alongs constitutional would require "reevaluation" of "the rule in Semayne's Case." Id. at 622 (Stevens, J., dissenting). Ironically, the actual decision in Semayne's Case declared the home a "castle and fortress" only against entries at the behest of private individuals, not in cases "when the King is [a] party." 77 Eng. Rep. at 195-96; see Payton v. New York, 445 U.S. 573, 592 (1980); id. at 605 (White, J., dissenting). This limitation remained sufficiently familiar as late as 1761 that counsel for the Crown, arguing for reissuance of writs of assistance in Massachusetts, could claim that "Every Body knows that the subject has the Priviledge of House only against his fellow subjects, not vs. the King either in matters of Crime or fine." John Adams, Minutes of the Argument, in 2 Legal Papers of John Adams 123, 130 (L. Kinvin Wroth \& Hiller B. Zobel eds., 1965).

144. The following term-its most recent-the Court said nothing about common law when approving an investigatory stop based on the suspect's flight from police in an area known for narcotics trafficking, see Illinois v. Wardlow, $120 \mathrm{~S}$. Ct. 673 (2000), when disapproving a stop and frisk based solely on an anonymous tip that the suspect was carrying a gun, see Florida v. J.L., 120 S. Ct. 1375 (2000), and when ruling that law enforcement agents carry out Fourth Amendment "searches" when they squeeze the baggage of bus passengers to feel for contraband, see Bond v. United States, $120 \mathrm{~S}$. Ct. $1462(2000)$. But that may have been because the Court found all three cases so easy to resolve under Terry, Katz, and their progeny. The result in Wardlow flowed directly from Terry itself, see Wardlow, $120 \mathrm{~S}$. Ct. at 676-77, and the losing argument in J.L. rested on a novel modification of Terry that appealed to none of the justices-a "firearm exception" to the "reasonable suspicion" traditionally required for a stop and frisk, see J.L., 120 S. Ct. at 1379-80. In Bond all but two of the justices had little difficulty finding that a passenger 


\section{B. What's New About the New Originalism}

The attention the Supreme Court has paid to common law in recent Fourth Amendment cases raises several questions. Is it sincere: is the Court in fact relying on common law to interpret the Fourth Amendment, or are the citations merely window dressing? Is it coherent: can eighteenth-century common law really decide modern search-and-seizure cases? Perhaps most important, is it wise: does it make sense to use the common law as the chief gauge of constitutional reasonableness?

I take up each of these matters below. First, though, I need to address a more basic question: is there anything truly novel here? Having claimed that the Court's recent decisions reflect a new Fourth Amendment originalism, I am obliged to explain what is new about it, particularly because the novelty may not be readily apparent.

Certainly the use of history in search-and-seizure law is not new: "[f]or at least a century, lawyers, judges, and legal scholars have employed history to explain the meaning of the Fourth Amendment."145 And neither Justice Scalia nor the Court has claimed that the resort to common law is innovative. On the contrary, Justice Scalia has defended this method of interpretation as a return to "first principle," 146 and both he and the Court have claimed to be following the methodological strictures of an increasingly prominent, seventy-five-year- old decision, Carroll $v$. United States. ${ }^{147}$ But cloaking innovation as tradition has itself been a familiar tactic of the common law since at least the time of Coke. ${ }^{148}$ The new Fourth Amendment originalism in fact breaks with tradition in the way it employs history to interpret the Fourth Amendment, and Carroll, in particular, is weak precedent for the Court's current approach.

1. The Old Use of History and the New. - For approximately three decades-from the late 1960s through the early I990s-history played only a small role in the Supreme Court's construction of the Fourth Amendment. The twin pillars of the approach the Warren and Burger Courts took to search and seizure, Katz v. United States and Terry v. Ohio, are thoroughly functional and ahistoric, both in the standards they announce and in their modes of reasoning. As I noted at the outset of this Article, criminal procedure scholars during this period mostly agreed with the Court that history was of little use in interpreting the Fourth Amendment.

So the new originalism would be noteworthy even if it were not truly new-even if it were simply a return to the Fourth Amendment jurispru-

placing luggage in an overhead compartment-an experience they all likely had sharedreasonably expected that no one would "feel the bag in an exploratory manner." $120 \mathrm{~S}$. Ct. at 1465. Justice Scalia joined Justice Breyer's dissent. See id. at 1465 (Breyer, J., dissenting).

145. Cloud, supra note 18 , at 1707 n.3.

146. California v. Acevedo, 500 U.S. 565, 583 (Scalia, J., concurring).

147. 267 U.S. 132 (1925).

148. See Pocock, supra note 72, at 30-55; Cuddihy, supra note 19 , at 215-33. 
dence of mid-century. But in fact the Court's recent search-and-seizure decisions differ significantly from the older cases.

Perhaps the most telling sign is Justice Frankfurter's fall from favor. At one time Frankfurter was the justice most closely identified with a historical approach to the Fourth Amendment. Professor Amsterdam wrote that Frankfurter "more than any other of the Justices sought the fourth amendment's meaning in its history." 149 Alfred Kelly, who found so little to admire in any of the justices' use of history, made an exception for Frankfurter, "the most history-minded Justice ever to sit on the Supreme Court." 150 So did Amsterdam, despite his general view that history offered "no help" in interpreting the Fourth Amendment. ${ }^{151}$ But citations to Frankfurter's Fourth Amendment opinions, once a staple of the Supreme Court's search-and-seizure decisions, have all but disappeared in recent years.

Part of the explanation is that Frankfurter was a strong advocate of the warrant requirement-the general principle that a search or seizure is unreasonable if it is made without a warrant. ${ }^{152}$ Telford Taylor's own reading of history led him to conclude that the warrant requirement has "stood the fourth amendment on its head," because "our constitutional fathers were not concerned about warrantless searches, but about overreaching warrants." ${ }^{153}$ Professor Amar is fully convinced by Taylor's argument, and as a consequence Frankfurter is one of the few modern justices whose Fourth Amendment opinions leave Amar nothing to praise. ${ }^{154}$ Justice Scalia, the architect of the new Fourth Amendment originalism, has also endorsed Taylor's position, ${ }^{155}$ and this no doubt has helped make Frankfurter's search-and-seizure opinions unattractive models for Scalia.

But there is more to it than the warrant requirement. Justice Frankfurter, as Professor Amsterdam observed, "looked to the history for a specific purpose." ${ }^{56}$ Frankfurter used the background of the Fourth Amendment to shed light on its underlying concerns, which in his view centered on the need to keep government searches and seizures under close judicial supervision. He did not see the Amendment as codifying

149. Amsterdam, supra note 15 , at 397 .

150. Alfred H. Kelly, Clio and the Court: An Illicit Love Affair, 1965 Sup. Ct. Rev. 119 , 129. For similar praise, see Henry J. Friendly, Mr. Justice Frankfurter and the Reading of Statutes, in Felix Frankfurter: The Judge 30, 47 (Wallace Mendelson ed., 1964) ("It would be a gross understatement to say that Justice Frankfurter would have been a great historian. He has been one-not only in his book, The Business of the Supreme Court, and in many law review articles, but in the opinions themselves.").

151. See Amsterdam, supra note 15, at 395 .

152. See United States v. Rabinowitz, 339 U.S. 56, 70 (1950) (Frankfurter, J., dissenting); Harris v. United States, 331 U.S. 145, 161-62 (1947) (Frankfurter, J., dissenting); Davis v. United States, 328 U.S. 582, 595 (1946) (Frankfurter, J., dissenting).

153. Taylor, supra note 70, at 23-24, 41.

154. See Amar, First Principles, supra note 17 , at 760 n.4.

155. See California v. Acevedo, 500 U.S. 565, 581-82 (1991) (Scalia, J., concurring); supra note 70 and accompanying text.

156. Amsterdam, supra note 15 , at 396. 
the particular set of common-law restrictions in effect at the time of enactment. He sought in history the general thrust of the Amendment, not its detailed applications. Frankfurter, in other words, treated the specific abuses giving rise to the Fourth Amendment as what Jed Rubenfeld has called "paradigm cases," and used them as Rubenfeld recommends: "to illuminate . . . what particular abuses most provoked those who framed and ratified the provision in question, and what it was about those abuses that most provoked them." 157 He shared this method with Justice Bradley's celebrated opinion for the Court in Boyd $v$. United States, ${ }^{158}$ and with the equally celebrated dissent by Justice Brandeis in Olmstead $v$. United States ${ }^{159}$ - the two most famous uses of history in Fourth Amendment jurisprudence.

The Court's recent search-and-seizure cases, and the opinions of Justice Scalia from which they derive, employ history for a different purpose. They view the Fourth Amendment as preserving particular legal protections in place at the time of its framing: putting certain "traditional common-law guarantees," as Justice Scalia has explained, "beyond time, place, and judicial predilection." 160

The notion of a relationship between "unreasonable searches and seizures" and searches forbidden by common law is far from a complete innovation. Even when the ahistoric approach to the Fourth Amendment was at its apogee, the Supreme Court occasionally consulted common law as a guide to reasonableness. But only as a very rough guide. In United States $v$. Watson, for example, the Court reaffirmed "the ancient common-law rule" permitting warrantless felony arrests on probable cause, but only after observing that the rule had been endorsed consistently throughout the nation's history by courts and legislatures at both the state and federal level. ${ }^{161}$ Similarly, Gerstein v. Pugh, ${ }^{162}$ the decision revisited in County of Riverside $v$. McLaughlin, ${ }^{163}$ concluded for pragmatic reasons that a suspect arrested without warrant cannot be held pretrial without a judicial determination of probable cause-and only after reaching this determination noted it had "historical support in the common law that has guided interpretation of the Fourth Amendment." 164 When the Court declined in Payton v. New York to extend the Watson rule to arrests in a private home, the justices noted that "the common-law rule on warrantless home arrests was not as clear as the rule on arrests in pub-

157. Jed Rubenfeld, Reading the Constitution as Spoken, 104 Yale L.J. 1119, 1170 (1995)

158. 116 U.S. 616 (1886); see Landynski, supra note 8, at 60-61.

159. 277 U.S. 438, 471 (1928) (Brandeis, J., dissenting); see White, supra note 23, at 149-57; Lessig, Fidelity in Translation, supra note 23, at 1239-40.

160. County of Riverside v. McLaughlin, 500 U.S. 44, 66 (1991) (Scalia, J., dissenting).

161. 423 U.S. 411, 415-24 (1976).

162. 420 U.S. 103 (1975).

163. 500 U.S. at 47.

164. Gerstein, 420 U.S. at 114. 
lic places," 165 but they also went out of their way to note that the common law, to the extent it reflected what "the Framers of the Amendment might have thought to be reasonable," was "relevant" but not "dispositive."166 They explained that " $[\mathrm{t}]$ here are important differences between the common-law rules relating to searches and seizures and those that have evolved through the process of interpreting the Fourth Amendment in light of contemporary norms and conditions," and that "this Court has not simply frozen into constitutional law those law enforcement practices that existed at the time of the Fourth Amendment's passage." 167 Justice White, who dissented in Payton, quoted this last statement with approval when he wrote for the Court in Tennessee $v$. Garmer, finding the use of deadly force to stop all fleeing felons "unreasonable," despite commonlaw approval of the practice. ${ }^{168}$ The old rule, he explained, no longer made sense. ${ }^{169}$

Truer antecedents to the new Fourth Amendment originalism can be found in the occasional suggestions made earlier, particularly in the first half of the nineteenth century, that the Fourth Amendment and its state constitutional analogs were "nothing more than an affirmance of the common law." 170 The best known of these is Justice Story's comment, quoted in Justice Scalia's McLaughlin dissent, that the Fourth Amendment "is little more than the affirmance of a great constitutional doctrine of the common law."171 Even these antecedents are imperfect. Unlike the Court's most recent pronouncements, they do not speak directly to a question I will take up later: whether the Amendment "affirms" common law as a permanent and unchanging set of rules, or as an organic assem-

165. 445 U.S. $573,596(1980)$.

166. Id. at 591 .

167. Id. at 591 n.33.

168. 471 U.S. $1,11,13$ (1985). Justice Marshall quoted the same language with approval in his opinion for the Court in Steagald v. United States, 451 U.S. 204, 217 n. I0 (1981), holding that an officer generally needs a search warrant, not just an arrest warrant, to arrest a suspect in a third party's home.

169. Garner, 471 U.S. at 14. Even Justice O'Connor, who dissented in Garmer and was joined by Chief Justice Burger and Justice Rehnquist, did not argue that the Fourth Amendment placed the common-law rule "beyond time, place, and judicial predilection." She did advocate, though, a softer version of the originalist methodology the Court was later to embrace. She acknowledged that "the requirements of the Fourth Amendment must respond to the reality of social and technological change," but urged that "fidelity to the notion of constitutional-as opposed to purely judicial-limits on governmental action requires us to impose a heavy burden on those who claim that practices accepted when the Fourth Amendment was adopted are now constitutionally impermissible." Id. (O'Connor, J., dissenting).

170. Wakely v. Hart, 6 Binn. 316, 319 (Pa. 1814). For a later example, see People $v$. Chiagles, 142 N.E. 583, 583 (N.Y. 1923) (Cardozo, J.) (opining that New York's statutory analog to the Fourth Amendment offers protection "not from all searches and seizures, but from search or seizure unreasonable in the light of common-law traditions"). Chiagles was cited in Califoruia v. Acevedo, 500 U.S. 565, 583 (1991) (Scalia, J., concurring).

171. 3 Story, supra note 89 , at 748, quoted in Riverside v. McLaughlin, 500 U.S 44, 71 (1991) (Scalia, J., dissenting). 
blage of practices and principles, capable of growth and adaptation. Moreover, except in a greatly diluted form, they never became part of the Supreme Court's official understanding of the Fourth Amendment. Boyd $v$. United States, ${ }^{172}$ the great nineteenth-century search-and-seizure case, prefigured Justice Frankfurter's approach to the Fourth Amendment, not Justice Scalia's, and Boyd remained the single most important guide to interpreting the Amendment well into the 1920s. ${ }^{173}$

Perhaps for this reason-and perhaps partly because Boyd no longer commands the respect it once did-Justice Scalia and the Court have not claimed Boyd as precedent for their current approach to the Fourth Amendment. Instead, they have turned to Carroll $v$. United States, ${ }^{174}$ the prohibition-era decision authorizing warrantless searcbes of automobiles based on probable cause. But even that case turns out, like Watson and Payton, to treat common law as "relevant" but not "dispositive." $175 \mathrm{Be}-$ cause Carroll has become such canonical authority in recent years, replacing Boyd as the early Fourth Amendment decision most often cited by the Court, it merits close inspection.

2. Carroll Redux. - Among the minor surprises of the Supreme Court's recent Fourth Amendment jurisprudence has been the resurgent prestige of Chief Justice Taft's majority opinion in Carroll, long familiar to students of criminal procedure principally as the original source of the "automobile exception" to the warrant requirement-the rule that cars may be searched based on probable cause without a warrant. Unlike Boyd, Carroll has never been a favorite of the commentators. An early, influential study wrote off Carroll as an "[i]ll-[s]tarred prohibition case," 176 and Taft's biographer treated it as one more sign that "there were no lengths to which the Chief Justice would not go, and along which he would not attempt to lead the court, in his determination to uphold prohibition enforcement." 177 The leading published history of searchand-seizure law, although sympathetic to the automobile exception, finds Taft's opinion-and, in particular, his use of history-flawed and unconvincing. ${ }^{178}$

But of late, the justices-particularly Justice Scalia and Justice Thomas, the two chief proponents of the new Fourth Amendment originalism-have invoked Carroll increasingly often, not just for the rule

172. 116 U.S. 616 (1886).

173. See supra notes $5-13$ and accompanying text.

174. 267 U.S. 132 (1925).

175. 1d. at $156-58$.

176. Forrest R. Black, A Critique of the Carroll Case, 29 Colum. L. Rev. 1068, 1068 n.* (1929).

177. 2 Henry F. Pringle, The Life and Times of William Howard Taft 989 (1939). Regarding Taft's crusade for stricter enforcement of prohibition laws, and criminal laws more generally, see Alpheus Thomas Mason, William Howard Taft: Chief Justice 227, 256, 259 (1964).

178. See Landynski, supra note 8 , at 90 . Professor Davies is even more critical. See Davies, supra note 20 , at $604-08$. 
it announced, but also for its interpretive method. In his concurrence in Minnesota $v$. Dickerson, for example, Scalia cited Carroll for the proposition that the reasonableness clause "is to be construed in the light of what was deemed an unreasonable search and seizure when it was adopted." 179 Justice Thomas invoked Carroll in Wilson v. Arkansas to buttress his suggestion for a unanimous Court that, to assess the scope of the Fourth Amendment, "we have looked to the traditional protections against unreasonable searches and seizures afforded by the common law at the time of the framing." 180 When Justice Thomas made a similar claim in his majority opinion in Florida $v$. White, writing that "[i]n deciding whether a challenged government action violates the [Fourth] Amendment, we have taken care to inquire whether the action was regarded as an unlawful search and seizure when the Amendment was framed," he again cited Carroll. ${ }^{181}$ And Justice O'Connor turned to Carroll in her history-based dissent in Vernonia School District 47J v. Acton ${ }^{182}-$ although, as we will see, she read Carroll differently than Scalia and Thomas.

Although Carroll may come closer to anticipating the new Fourth Amendment originalism than any other decision before 1995, Taft's methodology in Carroll was in fact looser, more ambiguous, and less wedded to history than Scalia and Thomas have suggested. The case arose when an undercover prohibition agent posing as a would-be whiskey buyer was introduced to Carroll and his codefendant. A sale was discussed but never took place. Several days later the agent and two other officers, apparently patrolling the road from Grand Rapids to Detroit, spotted the defendants in the same car they had driven to the undercover meeting. The agents pulled the car over and searched it. In the upholstery they found sixty-eight bottles of liquor, for possession of which the defendants were tried and convicted. ${ }^{183}$ The Supreme Court affirmed the convictions. Writing for the majority, Chief Justice Taft found the officers had probable cause to believe the defendants were carrying liquor, in part based on the undercover meeting, and in part based on the fact that "Detroit and its neighborhood along the Detroit River, which is the International Boundary, is one of the most active centers for introducing illegally into this country spiritous liquors for distribution into the interior."184 In retrospect the grounds for probable cause seem thin, and even at the time two dissenting justices voiced amazement that "merely because a man once agreed to deliver whiskey, but did not, he may be 149).

179. 508 U.S. 366, 379-80 (1993) (Scalia, J., concurring) (quoting Carroll, 267 U.S. at

180. 514 U.S. 927,931 (1995).

181. 526 U.S. $559,563-64$ (1999).

182. 515 U.S. 646, 668 (1995) (O’Connor, J., dissenting).

183. See Carroll v. United States, 267 U.S. 132, 134-36 (1925) (reporter's statement of the case).

184. 1d. at 160 . 
arrested whenever he ventures to drive an automobile on the road to Detroit!"185

Of more lasting significance, however, was Taft's conclusion for the Court that no warrant had been needed to search the car. "On reason and authority," he explained, "the true rule is that if the search and seizure without a warrant are made upon probable cause . . that an automobile or other vehicle contains that which by law is subject to seizure and destruction, the search and seizure are valid." 186 The reference to "reason and authority" suggested a twofold inquiry, as did Taft's following sentence: "The Fourth Amendment is to be construed in the light of what was deemed an unreasonable search and seizure when it was adopted, and in a manner which will conserve public interests as well as the interests and rights of individual citizens." 187

Justice Scalia, in his Dickerson concurrence, quoted the first but not the second half of this sentence. ${ }^{188}$ But the second half was not boilerplate. True, Taft devoted much of his opinion to history, in an effort to demonstrate

that the guaranty of freedom from unreasonable searches and seizures by the Fourth Amendment bas been construed, practically since the beginning of the Government, as recognizing a necessary difference between a search of a store, dwelling house or other structure in respect of which a proper official warrant readily may be obtained, and a search of a ship, motor boat, wagon or automobile, for contraband goods, where it is not practicable to secure a warrant because the vebicle can be quickly moved out of the locality or jurisdiction in which the warrant must be sought. ${ }^{189}$

But Taft's history had little to do with common law. It placed greatest emphasis on legislation shedding light on what searches and seizures Congress thought were reasonable, particularly Founding-era statutes that authorized customs officers to search ships without warrants ${ }^{190}$ - the same legislation later invoked in Wyoming $v$. Houghton and Florida $v$. White. ${ }^{191}$ More importantly, Taft appealed not just to history, but also to practicality. Although "[i]t would be intolerable and unreasonable," he said, for all cars to be subject to search, it was "certainly . . . reasonable," and therefore "fulfill[ed] the guaranty of the Fourth Amendment," to

185. Id. at 174 (McReynolds, J., dissenting, joined by Sutherland, J.).

186. Id. at 149 (opinion of the Court).

187. Id. (emphasis added).

188. See Minnesota v. Dickerson, 508 U.S. 366, 379 (1993) (Scalia, J., concurring). Professor Davies narrows Carroll in the opposite way: discounting Taft's appeal to history, he reads the decision to announce "that the Fourth Amendment prohibited only those searches that were "unreasonable" in "a modern, relativistic" sense. Davies, supra note 20 , at $73 \mathrm{I}-32$.

189. Carroll, 267 U.S. at 153.

190. See id. at 149-53.

191. See supra text accompanying notes 135-141. 
require probable cause but not warrants, where warrants were manifestly impractical. ${ }^{192}$

So the appeal to history in Carroll fell short of the new Fourth Amendment originalism in two ways. It did not focus on common law, and it was less thoroughgoing. Taft never explained what he thought the Court should do if considerations of public policy and individual "rights and interests" conflicted with what was considered an unreasonable search or seizure in I791, although the fact that he called for interpreting the Fourth Amendment "in light of" the original understanding suggested some flexibility. It was just as well for Taft's argument that he invoked history only halfheartedly, because, for reasons 1 will discuss later, his use of history was at best debatable. ${ }^{193}$

The justices, or some of them, have themselves recognized at times that Carroll involved something more than an inquiry into whether a particular form of search or seizure was thought unreasonable when the Fourth Amendment was adopted. The best example is Justice O'Connor's dissent, joined by Justice Stevens and Justice Souter, from the Court's approval in Acton of blanket drug testing for student athletes. ${ }^{194}$ O'Connor depicted Carroll as employing history in the way Boyd did: as clues to the general concerns underlying the Fourth Amendment. ${ }^{195}$ Stressing Taft's "simple yet powerful intuition" that searching cars without probable cause would be "intolerable and unreasonable," O'Connor read Carroll to identify " $[\mathrm{p}]$ rotection of privacy, not evenhandedness" as the "touchstone of the Fourth Amendment."196 And she argued that this understanding of the Amendment was consistent both with the eighteenth-century controversies leading to its enactment and with the Court's interpretation of the Fourth Amendment in the decades since Carroll. ${ }^{197}$

Justice O'Connor's vision of the Fourth Amendment may have been too dismissive of "evenhandedness," 198 and she may have read more into Carroll than Taft intended to say. The Court came closer to capturing the

192. Carroll, 267 U.S. at 153-54, 156.

193. See infra text accompanying notes $415-421$.

194. See Vernonia Sch. Dist. v. Acton, 515 U.S. 646, 666 (1995) (O'Connor, J., dissenting).

195. See id. at $668-70$.

196. Id. at 668,671 .

197. See id. at $669-76$.

198. See, e.g., Camara v. Municipal Court, 387 U.S. 523, 528 (1967) (noting that "[ $t]$ he basic purpose" of the Fourth Amendment, "as recognized in countless decisions of this Court, is to safeguard the privacy and security of individuals against arbitrary invasions by governmental officials"); Amar, First Principles, supra note 17, at 809 (suggesting that a "broader, more evenhanded search is sometimes more constitutionally reasonable"); Amsterdam, supra note 15, at 417 (arguing that a "paramount purpose of the fourth amendment is to prohibit arbitrary searches and seizures as well as unjustified searches and seizures"); Tracey Maclin, The Central Meaning of the Fourth Amendment, $35 \mathrm{Wm}$. \& Mary L. Rev. 197, 201 (1993) (contending that "the central meaning of the Fourth Amendment is distrust of police power and discretion"); Sklansky, supra note 115, at 
ambiguous reasoning of Carroll in United States $v$. Ross, when it extended Carroll to searches of containers found inside cars and grounded the earlier decision in considerations of "impracticability, viewed in historical perspective." 199 But O'Connor's reading of Carroll in Acton was at least as plausible as the one later embraced by the Court, with her approval, in Wilson v. Arkansas and Florida v. White. Painting Taft as Bradley, Brandeis, or Frankfurter is something of a stretch, but so is treating Carroll as strong authority for the new Fourth Amendment originalism.

\section{Why It Matters}

Together with its prolonged gestation, the novelty of the new Fourth Amendment originalism suggests it is a development worthy of attention. We do not deal here with a verbal formula chosen carelessly or even casually. We have instead a doctrine developed and promoted over a period of years by a justice particularly attentive to linguistic nuances, and then explicitly embraced by the Court. Nor do we find simply a restatement of what the Court has always said. The new originalism breaks dramatically with the ahistoric approach the Court has taken to the Fourth Amendment for most of the past half-century, and it differs substantially from the uses to which history was put even in opinions predating that period. The doctrine we confront is calculated and distinctive.

What is harder to tell with certainty is how much it will matter. The principal difficulty here could be called the problem of sincerity: is the Court genuinely conforming its view of reasonableness to eighteenth-century understandings, or is it manipulating eighteenth-century understandings to fit its own view of reasonableness? Put aside for the moment the larger questions whether there truly was a coherent common-law conception of what makes a search or seizure unreasonable, and if so whether we could hope to recapture it. I will return to these matters later. For now I want to raise more pedestrian questions. Assuming it is possible to decide Fourth Amendment cases by an appeal to the original understanding of "unreasonable searches and seizures," is there any reason to think that the Supreme Court is likely to engage in that enterprise? And, if not, why should anyone care about the new Fourth Amendment originalism?

What gives these questions weight is the remarkable if familiar fact that Supreme Court justices, like law professors, almost always find that the Framers' views mirror their own. It is the commonplace nature of this convergence that allowed the Court in Carroll to mandate construction of the Fourth Amendment "in the light of what was deemed an unreasonable search and seizure when it was adopted, and in a manner which will conserve public interests as well as the interests and rights of

308-29 (arguing that certain forms of racial inequity can make searches or seizures "unreasonable" within the meaning of the Fourth Amendment).

199. 456 U.S. 798, 806 (1981). 
individual citizens"-without the slightest hint that these two criteria could ever conflict. ${ }^{200}$ The same phenomenon allowed the Court later to speak confidently of "impracticability, viewed in historical perspective," as though those words actually conveyed some kind of meaning. ${ }^{201}$

Justice Scalia would run in horror from a phrase like that, and he is adamant that the Constitution should be read as the Framers actually understood it, not as we might prefer to read it. But even he seems inevitably to find that the Framers had it right. His opinions in McLaughlin, Acevedo, Dickerson, Carter, and Houghton contain no suggestion that anything about the original understanding is unfortunate, or that he might craft the Fourth Amendment differently, were he writing from scratch. The original understanding always turns out to make excellent sense-a happy coincidence also encountered by Justice Thomas in his opinions for the Court in Wilson v. Arkansas and Florida v. White.

The concern this raises is not that the new Fourth Amendment originalism is just a strategy to advance a law-and-order agenda. There is plenty of evidence that the current Court is particularly sympathetic to law enforcement interests, ${ }^{202}$ but there is more to the new originalism than that. At least there appears to be for Justice Scalia. McLaughlin, the case in which Scalia first turned to the common law to interpret the reasonableness clause of the Fourth Amendment, was also a case in which he chided the Court for inadequately protecting the rights of criminal suspects. ${ }^{203}$ In Dickerson, Scalia suggested that the common law cast doubt on the constitutional reasonableness of the frisks upheld in Terry $v$. Ohio. ${ }^{204}$ Whatever may be true of the broader Court, and whatever may have been true of Chief Justice Taft, ${ }^{205}$ Scalia does not seem to have been attracted to Fourth Amendment originalism simply to help the police. ${ }^{206}$

But opinions need not be rigidly partisan in order to be result oriented. Because Scalia's originalism has never driven him to interpret the Fourth Amendment in a manner that seems contrary to his own preferences, the question lingers whether the originalism has any cash value. In Louis Michael Seidman's words, originalism does "independent work"

200. Carroll v. United States, 267 U.S. 132, 149 (1925) (emphasis added).

201. Ross, 456 U.S. at 806 .

202. For some of the evidence, see Sklansky, supra note 115, at 298-308.

203. See County of Riverside v. McLaughlin, 500 U.S. 44 (1991) (Scalia, J., dissenting); see supra text accompanying notes 82-90.

204. 508 U.S. 366,2140 (1993) (Justice Scalia, concurring); see supra text accompanying notes 105-113.

205. See supra note 177 and accompanying text.

206. Cf. Maryland v. Craig, 497 U.S. 836, 860-70 (1990) (Scalia, J., dissenting) (arguing for stricter application of the Confrontation Clause on originalist grounds). Search-and-seizure doctrines designed to aid law enforcement can of course come cloaked in rulings nominally favoring defendants. See Sklansky, supra note 115, at 300-07. But Scalia's opinions in McLaughlin and Dickerson do not just throw crumbs at criminal suspects, and his earlier opinions--notably Hicks--do not suggest a jurist on a simple lawand-order crusade. See supra text accompanying notes $46-56$. 
only when it "requires judges to reach results that they would not reach using some other theory." 207 By this standard, it is unclear whether the new Fourth Amendment originalism has ever done any "independent work," either for Scalia or for the Court. So is it worth worrying about?

lt is, for two reasons. First, whatever its limitations as theory, the new Fourth Amendment originalism has distinct strengths as rhetoric. Even in cases where it does not affect results, it can help to legitimize them. All varieties of constitutional originalism do this, by attributing outcomes not to unelected judges but to the collective determination of an older and particularly revered generation. But the new Fourth Amendment originalism goes one better, by appealing not just to the wisdom of the Framers, but to the wisdom of the ages. Not for nothing have AngloAmerican jurists since Coke turned for justification to the time-honored pronouncements of the common law. ${ }^{208}$

Second, over the long term the new Fourth Amendment originalism could well have substantive consequences. 1 argue below that "the common law" will rarely if ever provide a determinate answer to modern search-and-seizure questions. ${ }^{209}$ But the rhetoric of the new Fourth Amendment originalism legitimizes some outcomes more easily than others and is relatively uncongenial to certain broad uses to which the Fourth Amendment might otherwise be put. The problem is not so much the answers provided by eighteenth-century common law-those are rare-but rather the limited range of the questions it asked.

To take perhaps the most obvious example, of late the Supreme Court has studiously avoided considerations of equality in assessing the reasonableness of searches and seizures. Constitutional challenges to discrimination, the Court has explained, should be raised under "the Equal Protection Clause, not the Fourth Amendment."210 Nevertheless even Professor Amar, who echoes Justice Scalia's call to return Fourth Amendment law to "first principles," suggests that constitutional reasonableness today may depend in part on considerations of race, class, and gender equity. ${ }^{211}$ These concerns, however, are difficult to read into the common law of 1791. Indeed, as 1 discuss later, eighteenth-century rules of search and seizure, far from reflecting a broad commitment to equality,

207. Louis Michael Seidman, This Essay is Brilliant/This Essay is Stupid: Positive and Negative Self-Reference in Constitutional Practice and Theory, 46 UCLA L. Rev. 501, 550 (1998).

208. See supra notes $72-73$ and accompanying text. On Coke's "elasti[c]" use of the common law of search and seizure, "misrepresent[ing] novelty as antiquity," see Cuddihy, supra note 19 , at 204-33.

209. See infra text accompanying notes 336-414.

210. Whren v. United States, 517 U.S. 806, 813 (1996).

211. See Amar, First Principles, supra note 17, at 808-09. For related arguments, see, e.g., Amsterdam, supra note 15, at 401, 416-17; Sklansky, supra note 115, at 326-29; Steiker, Second Thoughts, supra note 18, at 830-44; William J. Stuntz, The Distribution of Fourth Amendment Privacy, 67 Geo. Wash. L. Rev. 1265, 1265-67 (1999). 
systematically codified class privilege. ${ }^{212}$ So although the new Fourth Amendment originalism may not be to blame for the absence of race, class, and gender considerations from current search-and-seizure doctrine, the rhetoric of the new originalism makes correction of the absence less likely.

Other long-range implications, if less obvious, may be no less important. Dramatic improvements in the technology of data management and retrieval, for example, may increasingly make what government does with information as important as what information the government gets. ${ }^{213}$ Harold Krent has sensibly suggested tbat the reasonableness of a search should depend in part on how, and for what purposes, the government disseminates what it learns. ${ }^{214}$ But precisely because eighteenth-century record keeping was so rudimentary, the common law showed little interest in how information was shared. Accordingly, if use restrictions become part of the Fourth Amendment, it will be in spite of the new Fourth Amendment originalism. Even in Wilson $v$. Layne, when striking down media "ride-alongs," the Court could draw no real guidance from common law-and that was a case involving not just the use of information, but the conduct of the search itself. 215

As Wilson v. Layne illustrates, the new Fourth Amendment originalism will never prevent the justices from taking search-and-seizure law where they want to take it. In addition to the indeterminacy of the resort to "common law" - a matter I take up below-the Court has made clear that it will continue to employ "traditional standards of reasonableness" when the common law "yields no answer."216 But changed circumstances alone mean that whether the common law yields an answer will depend on what counts as an answer. Does the common law tell us the reasonableness today of a frisk prior to arrest? Perhaps, Justice Scalia suggested in Dickerson-but perhaps not, he ultimately conceded, if colonial constables had fewer worries about "concealed weapons capable of harming the interrogator quickly and from beyond arm's reach."217 Can the common law say whether electronic surveillance constitutes a search? Justice Brandeis thought not in Olmstead, and the Court agreed in Katz, but Justice Black was unconvinced: "wiretapping is nothing more than eavesdropping by telephone," and eavesdropping is hardly new. ${ }^{218}$ Which common-law rules, if any, do racial ghettoes and computerized data banks

212. See infra text accompanying notes 408-414.

213. See Harold J. Krent, Of Diaries and Data Banks: Use Restrictions Under the Fourth Amendment, 74 Tex. L. Rev. 49, 51 (1995); cf. Jerry Kang, Information Privacy in Cyberspace Transactions, 50 Stan. L. Rev. 1193, 1202-45 (1998) (describing threats to privacy posed by "the emerging Global Information Infrastructure").

214. See Krent, supra note 213 , at $51 \&$ n.14.

215. 526 U.S. 603, 614-18 (1999); see supra notes 142-144 and accompanying text.

216. Wyoming v. Houghton, 526 U.S. 295, 299-300 (1999).

217. Minnesota v. Dickerson, 508 U.S. 366, 382 (1993) (Scalia, J., concurring)

218. Katz v. United States, 389 U.S. 347, 366 (1967) (Black, J., dissenting). 
render obsolete? The Court has left itself more than enough wiggle room to respond however it wants.

But the rhetoric of the new Fourth Amendment originalism suggests that eighteenth-century common law will likely exert a strong gravitational pull on future search-and-seizure jurisprudence, as it already has in the separate opinions of Justice Scalia. That gravitational force will tug the Court away from issues to which many people would like it to attend, and toward considerations that will strike some observers as antiquated. 1t may lead the Court to question, as it has already led Justice Scalia to question, such fixtures of modern Fourth Amendment law as the warrant requirement, the Katz test for a search, and the Terry rules for investigatory stops. In short, the new originalism may have large consequences.

Those consequences alone are not reason to reject it. But they do suggest that before the Court further commits itself to the new Fourth Amendment originalism, the justices would be wise to consider carefully whether it has any justification. I turn now to that question.

\section{Assessing the New Originalism}

By its terms the Fourth Amendment does not prohibit searches and seizure "illegal at common law;" it prohibits searches and seizures that are "unreasonable." As Carol Steiker has pointed out, no other provision of the Constitution seems to call so plainly for an open-ended interpretation. ${ }^{219}$ Might there nonetheless be reason to treat the Amendment as a codification of common law?

Before addressing that question, it is worth noting certain ironies. Justice Scalia, the chief proponent of the new Fourth Amendment originalism, is also the Court's most articulate defender of "textualism," the idea that the words in the Constitution, and in statutes, should be given their plain and natural meaning.220 Moreover, like some other selfprofessed "textualists," Justice Scalia has pointed to the common law as a model for how judges engaged in statutory or constitutional interpretation should not approach their work. ${ }^{221}$ In his Tanner Lectures, perhaps the fullest statement of his judicial philosophy, Scalia painted commonlaw judging as not just antidemocratic but self-indulgent: "intellectual fun" that amounts to "playing king-devising, out of the brilliance of one's own mind, those laws that ought to govern mankind." ${ }^{222}$ The com-

219. See Steiker, Second Thoughts, supra note 18 , at 824 .

220. See Antonin Scalia, Common-Law Courts in a Civil-Law System: The Role of United States Federal Courts in Interpreting the Constitution and Laws, in A Matter of Interpretation: Federal Courts and the Law 3, 9-29 (Amy Gutmann ed., 1997) [hereinafter Scalia, Common-Law Courts].

221. Cf., e.g., Alex Kozinski, The Case of the Speluncean Explorers: RevisitedJustice Kozinski, 112 Harv. L. Rev. 1876, 1876-77 (1999) (arguing similarity).

222. Scalia, Common-Law Courts, supra note 220, at 7, 9-14, 38-40. 
mon law, in short, embodies for Scalia the same evils as Judge Bork's opinion in Ollman v. Evans. ${ }^{223}$

There is no logical inconsistency in renouncing common-law methodology and yet interpreting the Fourth Amendment to incorporate the substantive rules of the common law. Indeed, as I discuss below, it is precisely Scalia's discomfort with "the Mr. Fix-it mentality of the common-law judge" that has driven him to read certain products of that mentality into the Fourth Amendment. ${ }^{224}$ Nonetheless, the preeminent importance attached to eighteenth-century common law by the new Fourth Amendment originalism sits oddly with Scalia's repudiation of the common-law "mind-set," and even more oddly with his insistence that "[ $\mathrm{t}]$ he text is the law, and it is the text that must be observed."225

Unfortunately, neither Justice Scalia nor the Court has done much to explain their refusal to assume the Fourth Amendment means what it appears to say. Three possible explanations suggest themselves, and 1 will consider each in turn. The first is that the plain language of the Fourth Amendment, read with sensitivity to context, really does support the Court's interpretation. The second is that the Fourth Amendment was intended to codify common-law rules, even if it does not say so. The third is that the new Fourth Amendment originalism, regardless how it squares with the actual language and intent of the Fourth Amendment, best serves the fundamental aims of the Constitution, by keeping both judicial review and majority rule within proper bounds. None of these arguments, I conclude, is ultimately convincing.

223. 750 F.2d 970 (D.C. Cir. 1984) (en banc), cert. denied, 471 U.S. 1127 (1985); see supra text accompanying notes 31-44; cf. Antonin Scalia, Assorted Canards of Contemporary Legal Analysis, 40 Case W. Res. L. Rev. 581, 596 (1989-90) (quoting with approval Bell v. Maryland, 378 U.S. 226, 341-42 (1964) (Black, J., dissenting) ("Our duty is simply to interpret the Constitution, and in doing so the test of constitutionality is not whether a law is offensive to our conscience or to the 'good old common law,' but whether it is offensive to the Constitution.")).

224. Scalia, Common-Law Courts, supra note 220, at 14. Robert Goldstein has pointed out to me that "Mr. Fix-it" is an odd way to refer to the cautious, precedent-bound method of the traditional common-law judge; it sounds more like a caricature of a modern, law-and-economics approach to adjudication. On the distortions in Scalia's view of common-law judging, see infra text accompanying notes 420-431.

225. Scalia, Common-Law Courts, supra note 220 , at 13,22 . Textualism and the new Fourth Amendment originalism can be reconciled, after a fashion, by viewing each as a rule of thumb, employed pragmatically to protect certain fundamental aspects of constitutional democracy. Thomas Grey suggests that this kind of pragmatism lies at the heart of Justice Scalia's whole jurisprudence. See Thomas C. Grey, The New Formalism 17-19, 26-28 (Sept. 6, 1999) <http://papers.ssm.com/paper.taf?abstract_id=200732> (unpublished manuscript on file with the Columbia Law Review). As 1 discuss below, see infra text accompanying notes 325-330, Justice Scalia has indeed defended the new Fourth Amendment originalism on the ground that it will help restrain majoritarian excesses and limit the antidemocratic risks inherent in the delegation of authority to unelected judges. But, for reasons 1 will explain, he exaggerates both the determinacy of the new approach and the subjectivity inherent in the Court's traditional method of interpreting the Fourth Amendment. See infra text accompanying notes 335-444. 
A. Text

On its face the reasonableness clause of the Fourth Amendment says nothing about common law. But Justice Scalia himself has stressed that "[i]n textual interpretation, context is everything," and that the ultimate question should be what the words would have meant to an "intelligent and informed" reader at the time they were written. ${ }^{226}$ So a sophisticated textualist reading of the reasonableness clause must take into account both late-eighteenth-century usage and the surrounding context of the rest of the Bill of Rights. ${ }^{227}$ Would such a reading support the new Fourth Amendment originalism?

An argument can be constructed that it would. It starts with the wellknown fact that the Revolutionary generation was steeped in both the rules and the rhetoric of the common law. Colonial lawyers trained with the writings of Coke and Blackstone, and even educated laypersons generally had a rudimentary knowledge of English legal precedents. ${ }^{228}$ Moreover, the colonists regularly used the language of the common law to support their claims against Great Britain. ${ }^{229}$ The most famous example of this was the unsuccessful oral argument by James Otis in 1761 against the renewal of writs of assistance in Massachusetts-an argument later hailed by John Adams as "the first scene of the first Act of Opposition to the arbitrary Claims of Great Britain." ${ }^{230}$ Otis drew heavily on the

226. Scalia, Common-Law Courts, supra note 220, at 37-38; cf., Oliver Wendell Holmes, The Theory of Legal Interpretation, 12 Harv. L. Rev. 417, 417 (1899) (suggesting that the question should be "what those words would mean in the mouth of a normal speaker of English, using them in the circumstances in which they were used").

227. Akhil Amar has made prominent use of the latter sort of context throughout his constitutional scholarship. He explains and defends his methodology in Akhil Reed Amar, Intratextualism, 112 Harv. L. Rev. 747 (1999). For a spirited response, see Adrian Vermeule \& Ernest A. Young, Hercules, Herbert, and Amar: The Trouble with Intratextualism, 113 Harv. L. Rev. 730 (2000). On the role of context generally in textualist interpretation, see Paul Brest, The Misconceived Quest for the Original Understanding, 60 B.U. L. Rev. 204, 206-09 (1980).

228. See Harry W. Jones, The Common Law in the United States: English Themes and American Variations, in Political Separation and Legal Continuity 91, 96-97 (Harry W. Jones ed., 1976); supra note 73. Edmund Burke made reference to the Americans' widespread familiarity with common law in his March 1775 speech to Parliament urging conciliation with the colonies: "In no country perhaps in the world is the law so general a study. The profession itself is numerous and powerful, and in most provinces it takes the lead. . . But all who read, and most do read, endeavor to obtain some smattering in that science." Edmund Burke, Speech in Support of Resolutions for Conciliation with the American Colonies (Mar. 22, 1775), in On the American Revolution 70, 85 (Elliott Robert Barkan ed., 1966).

229. See Bailyn, supra note 73 , at $30-31$.

230. Adams, supra note 143, at 107 (quoting Mar. 29, 1817 letter from Adams to Wiliam Tudor). Adams no doubt exaggerated the argument's impact. See O.M. Dickerson, Writs of Assistance as a Cause of the Revolution, in The Era of the American Revolution 40, 43 (Richard B. Morris ed., 1939). But Akhil Amar goes too far in suggesting that the controversy over writs of assistance had little to do with adoption of the Fourth Amendment. See Amar, First Principles, supra note 17, at 772. First, the influence on Adams alone was significant, because he drafted the 1780 Massachusetts Declaration of 
common law, particularly Coke's statement in Dr. Bonham's Case that any acts of Parliament "against common right and reason" will he "controul[ed]" by the common law and "adjudge[d] . . void."231 Otis was an exceptional figure in many regards, including his essentially pre-Stuart constitutionalism: like Coke, Otis struggled to reconcile a commitment to parliamentary supremacy with a rejection of the very notion of absolute sovereiguty. ${ }^{232}$ But Otis was far from unique in his respect for the common law. Indeed, "[t]he persistent appeals to the common law in the constitutional struggles leading up to the American Revolution 'created a regard for its virtues that seems almost mystical." "233

The English common-law tradition to which the revolutionaries appealed often tied legality to "reasonableness." Starting in the twelfth century, common-law judges used the test of "reasonableness" to decide which local customs to enforce nationwide; hy the fourteenth century the common law derived much of its legitimacy from the notion that it embodied "right reason." 234 Coke, as his opinion in Bonham's Case suggests, continued and in some ways enlarged on this rhetorical practice. Coke's

Rights, which included a guarantee against "unreasonable searches and seizures," and which served as the source for the similar language in the Fourth Amendment. See Landynski, supra note 8, at 38-39; Levy, supra note 20, at 228; Cuddihy, supra note 19, at 1240-41. Second, Adams was not the only one impressed. Following the argumentwhich received heavy coverage in the local press-Otis was elected to the Massachusetts House of Representatives by a nearly unanimous vote. See Cuddihy, supra note 19, at 817. Third, popular opposition to writs of assistance was not limited to Massachusetts but extended throughout most of the colonies. See Dickerson, supra, at 43. True, arguments over ratification of the Constitution referred repeatedly to "general warrants" and rarely to "writs of assistance." See Amar, First Principles, supra note 17, at 772 n.53; Amar, Boston, supra note 18 , at 77 . But that may mean little, because the colonists thought of the writs as general warrants, and often called them by that name. See Davies, supra note 20, at 561; Dickerson, supra, at 62 ; Cuddihy, supra note 19 , at 1125,1131 . Indeed, it was partly because they grouped writs of assistance together with general warrants that the Americans followed with such interest the legal challenges to general warrants in Britain. See id. at $1117-31$.

231. 77 Eng. Rep. 646 , 652 (C.P. 1610); see Adams, supra note 143, at 125-28. A surprisingly lively debate continues over whether Coke meant to describe a rule of judicial review or simply a canon of statutory construction. For the former view, see Corwin, supra note 73, at 43-50; John V. Orth, Did Sir Edward Coke Mean What He Said?, 16 Const. Commentary 33, 33 (1999); Theodore F.T. Plucknett, Bonham's Case and Judicial Review, 40 Harv. L. Rev. 30, 31 (1926). For the latter interpretation, see Adams, supra note 143, at $118 \& \mathrm{n} .36$, and sources cited therein.

232. See Stoner, supra note 75, at 190-92; Gordon S. Wood, The Creation of the American Repuhlic 1776-1787, at 9, 263-65, 293 (1969); Mullet, supra note 73, at 469. On the Stuart assertion of absolute sovereiguty-the seventeenth-century precursor to legal positivism-see John Neville Figgis, The Divine Right of Kings 228-32 (2d ed. 1914); Berman, supra note 72, 1667-73; Thomas C. Grey, Origins of the Unwritten Constitution: Fundamental Law in American Revolutionary Thought, 30 Stan. L. Rev. 843, 852 (1978).

233. Morton J. Horwitz, The Transformation of American Law, 1780-1860, at 5 (1977) (quoting 1 The Law Practice of Alexander Hamilton 11 (J. Goebel ed., 1964)); see Colbourn, supra note 75, at 25; Corwin, supra note 73, at 23-25; Plucknett, supra note 231, at 62 .

234. Corwin, supra note 73 , at 26. 
seventeenth-century Institutes, the legal authority most revered by the American revolutionaries, ${ }^{235}$ celebrated the common law as a practically flawless system, "the absolute perfection of reason."236 The seventeenthcentury English radical Algernon Sidney, also a great favorite of the revolutionaries, ${ }^{237}$ called the common law "written reason, retaining some measure of divine perfection." ${ }^{338}$ This kind of thing reached something of a pinnacle in the eighteenth century with the publication of Blackstone's Commentaries, that eminently readable "exemplar and model of legalistic and judicial obscurantism," ${ }^{239}$ which by the end of the century had replaced Coke's Institutes as the text of choice for America's aspiring lawyers. ${ }^{240}$ Blackstone went much further than Coke in defending parliamentary supremacy, ${ }^{241}$ but the Commentaries reaffirmed that "the law is the perfection of reason," and taught on almost every page that "what is not reason is not law." 242 Unsurprisingly, Americans read Blackstone more for this lesson than for his endorsement of Parliament's absolute sovereignty. ${ }^{243}$ And well into the nineteenth century even British courts occasionally used the term "unreasonable" to describe a custom contrary to the common law. ${ }^{244}$

235. See id. at 41, 76; Levy, supra note 20, at 222-23; Mullett, supra note 73 , at 458 ; Waterman, supra note 73, at 635 .

236. Edward Coke, The Second Part of the Institutes of the Laws of England 179 ( $6^{\text {th }}$ ed., London, Thomas Basset 1681) (1642) [hereinafter Coke, The Second Part of the Institutes].

237. See Robbins, supra note 73 , at $267-68$.

238. 2 Sidney, supra note 73 , at 120 .

239. Corwin, supra note 73 , at 85 .

240. See Jones, supra note 228, at 108; Dennis R. Nolan, Sir William Blackstone and the New American Republic: A Study of Intellectual Impact, 51 N.Y.U. L. Rev. 731, 737-38 (1976).

\section{Blackstone stated:}

[I]f the parliament will positively enact a thing to be done which is unreasonable, 1 know of no power in the ordinary forms of the constitution, that is vested with authority to control it [for] the legislature, being in truth the sovereign power, is always of . . . absolute authority: it acknowledges no superior upon earth . . . .

1 Blackstone, supra note 143 , at *90-*91; see Stoner, supra note 75 , at 174-75; Duncan Kennedy, The Structure of Blackstone's Commentaries, 28 Buff. L. Rev. 209, 242-43, 269-71 (1979).

242. 1 Blackstone, supra note 143 , at $* 70$; see Daniel J. Boorstin, The Mysterious Science of the Law 109 (1941); cf. Charles Dickens, Bleak House 12 (Bantam Books 1983) (1853) (describing Leicester Dedlock's opinion of chancery court "as a something, devised in conjunction with a variety of other somethings, by the perfection of human wisdom, for the eternal settlement (humanly speaking) of everything").

243. See Levy, supra note 20, at 232; Perry Miller, The Life of the Mind in America: From the Revolution to the Civil War 130, 164 (1965).

244. Carleton Kemp Allen, Law in the Making 97 (1927). For a similar American usage, see Davey v. Turner, 1 Dall. 11, 12 (Pa. 1764):

On the Part of the Plaintiff it was urged, that by Law a Feme Covert cannot convey her Estate but by fine; in which she must be examined by Writ; that the Usage in this case was not sufficient to alter the Law, not being from time immemorial, and was unreasonable, because it had no lawful commencement, a Feme being supposed by the Law to be under the coercion of her Husband . . . . 
Of course "reason" did not mean exactly the same thing to all these writers. To Coke, for example, it meant "artificial reason," reached not through individual reflection but through centuries of "long study, observation, and experience." 245 For his sixteenth-century predecessor Christopher St. German, "reason" and "reasonable" were the common law's labels for what ecclesiastical courts called the "law of nature."246 And Blackstone's "reason" was the "reason" of the Enlightenment, rooted rhetorically in logic and direct observation-albeit tempered, in Blackstone's case, with a deep conservatism that anticipated the subsequent writings of Edmund Burke. ${ }^{247}$ Nonetheless, the important point for present purposes is the linguistic continuity. Given this long tradition, familiar to eighteenth-century Americans, perhaps "intelligent and informed" readers in 1791 would have understood "unreasonable searches and seizures" to mean searches and seizures contrary to common law. ${ }^{248}$

245. Edward Coke, The First Part of the Institutes of the Laws of England 97b (14th ed., Dublin, James Moore 1791) (1628)) [hereinafter Coke, The First Part of the Institutes]:

[1]f all the reason that is dispersed into so many severall heads, were united into one, yet could he not make such a law as the law in England is; because by many successions of ages it hathe beene fined and refined by an infinite number of grave and learned men, and by long experience growne to such a perfection, for the government of this realme, as the old rule may be justly verified of it, Neminem oportet esse sapientiorem legibus: no man out of his own private reason ought to be wiser than the law, which is the perfection of reason.

For helpful discussions of Coke's concept of "artificial reason," see Corwin, supra note 73, at 34-39; Stoner, supra note 75, at 22-26; Berman, supra note 72, at 1689-94; John Underwood Lewis, Sir Edward Coke (1552-1633): His Theory of "Artificial Reason" as a Context for Modern Basic Legal Theory, 84 L.Q. Rev. 330, 334-39 (1968).

246. See Christopher St. German, Doctor and Student 7, 13 (T.F.T. Plucknett \& J.L. Barton eds., Selden Soc'y 1974) (1580); Frederick Pollock, The History of the Law of Nature, in Essays in the Law 31, 57 (1922); Berman, supra note 72, at 1659.

247. See Boorstin, supra note 242, at 120-36; Corwin, supra note 73, at 85-86; Stoner, supra note 75, at 170-75; Kennedy, supra note 241, at 231-34, 250-51, 269-71; Robert Willman, Blackstone and the 'Theoretical Perfection' of English Law in the Reign of Charles 1I, 26 Hist. J. 39, 50-53 (1983).

248. Professor Davies makes the slightly different suggestion that "the Framers would have understood 'unreasonable searches and seizures'" to refer not "to mere 'unlawful' intrusions by warrantless officers," hut only to searches and seizures that were "gross[ly]" or "inherently" illegal at common law, which is to say "searches or arrests made under that most illegal pretense of authority-general warrants." Davies, supra note 20, at 692-93; see id. at 736. But there is no evidence that late-eighteenth-century Americans distinguished between "mere" illegality and "gross" or "inherent" illegality. Moreover, Davies means by "general warrants" the kind of open-ended warrants banned by the second clause of the Fourth Amendment, see id. at 558, 578-79, so his reading of the first clause has the awkward effect of making the two clauses say substantially the same thing. (Davies suggests the first clause served to justify the second and to clarify that it covered only warrants to search or seize "persons, papers, houses, or effects." See id. at 550, 554. This is not a reading to which the syntax of the Amendment naturally lends itself.) Beyond these two problems, Davies's suggestion shares the central difficulty of a textualist defense of the new Fourth Amendment originalism: as I explain below, "unreasonable" meant in lateeighteenth-century America essentially what it means today. 
Perhaps, but probably not. As Paul Brest reminds us, most of those who ratified the Constitution and adopted the Bill of Rights were not lawyers; ${ }^{249}$ they would have been particularly unlikely to view "unreasonable search and seizure" as a term of art. Moreover, not even lawyers used "unreasonable search and seizure" as a term of art in the eighteenth century. The phrase apparently originated in the Massachusetts Declaration of Right, drafted by John Adams in 1780; it does not appear in earlier legal writing. ${ }^{250}$ The term "unreasonable," moreover, almost always meant in the late-eighteenth-century what it means today: contrary to sound judgment, inappropriate, or excessive. ${ }^{251}$ That is the usage suggested by dictionaries in use at the time. ${ }^{252}$ That is also how the term was used in political rhetoric. In The Federalist Papers, for example, "unreason-

249. See Brest, supra note 227, at 206 n.11.

250. See Nelson B. Lasson, The History and Development of the Fourth Amendment to the United States Constitution 82 (Johns Hopkins U. Studies in Historical Political Science, Series 15, No. 2, 1937); Cuddihy, supra note 19, at 1240-41. Cuddihy concludes that "[a]ny attempt to explain the amendment by elucidating its proximate sources goes in a circle that ends where it started, with a common core of vague generalizations that are not self-explanatory." 1d. at 1477. Professor Davies disagrees. He argues that Adams, in part because of his familiarity with Otis's argument against the Massachusetts writs of assistance, viewed "unreasonable" as "a pejorative synonym for gross illegality or unconstitutionality." Davies, supra note 20, at 686-93. But the evidence Davies assembles at best suggests that Adams, like Otis and Coke, thought that unreasonableness could make something illegal at common law, not that the term "unreasonable" meant "illegal at common law," or even "grossly illegal at common law." Being reckless can make one liable, but that does not turn "reckless" into a synonym for "liable": "Don't be reckless" means something different from "Don't be liable."

251. See, e.g., The Random House Dictionary of the English Language 2084 (Stuart Berg Flexner \& Leonore Crary Hauck eds., 2d ed. 1987) (defining unreasonable as "not guided by reason or sound judgment" or "excessive, immoderate or exorbitant; unconscionable"); cf. David Mellinkoff, Mellinkoff's Dictionary of American Legal Usage 539 (1992) (noting that "reasonable" "means in the law what it means in ordinary English: rational, just, fair-minded, not too much and not too little, etc.").

252. See, e.g., Thomas Dyche \& William Pardon, A New English Dictionary (9th ed., London, C. Ware 1758) (defining "reasonable" as "agreeable to the rules of reason, just, right, and fit to be done"; "unreasonable" as "rash, inconsiderate, offending against, or contrary to the dictates of justice, reason, or equity"; and "reason" as "that faculty of the mind that weighs and considers the nature and property of things, and makes conclusions accordingly, and also distinguishes between good and evil"); John Entick, Entick's New Spelling Dictionary 261 (2d Wilmington ed., Wilmington, Del., Peter Brynberg 1803) (defining "reasonable" as "endued with reason, rational, just"; and "reason" as "cause, motive, principle, moderation"). Both Dyche's dictionary and Entick's dictionary were used by late-eighteenth-century Americans, including members of the Congress that adopted the Bill of Rights. See Cuddihy, supra note 19, at 1486 n.249. Noah Webster, a lawyer as well as lexicographer, gave similar definitions for "reasonable":

1. Having the faculty of reason; endued with reason. 2. Governed by reason; being under the influence of reason; thinking, speaking or acting rationally or according to the dictates of reason. 3. Conformable or agreeable to reason; just; rational. 4. Not immoderate. 5. Tolerable; being in mediocrity; moderate. 6 . Not excessive; not unjust.

Noah Webster, An American Dictionary of the English Language 673 (8th ed., New York, White, Gallaher \& White 1831). 
able" means either excessive ${ }^{253}$ or implausible ${ }^{254}$-it never means illegal, or condemned by common-law courts. Thomas Paine employs the word similarly. ${ }^{255}$ And so, for the most part, do late-eighteenth-century American judges. ${ }^{256}$

Nor do the other provisions of the Bill of Rights-to employ the kind of "intratextualism" championed by Professor Amar ${ }^{257}$-suggest that the Fourth Amendment uses the term "unreasonable" in any but the ordinary way. The Bill of Rights includes some very specific protections, for example the command in the Third Amendment that "[n]o Soldier shall, in time of peace be quartered in any house, without the consent of the Owner."258 It also contains at least one provision explicitly safeguarding a previously established entitlement: the Seventh Amendment proclaims

253. See The Federalist No. 57, at 353 (James Madison) (Clinton Rossiter ed., 1961):

Were the objection to be read by one who had not seen the mode prescribed by the Constitution for the choice of representatives, he could suppose nothing less than that some unreasonable qualification of property was annexed to the right of suffrage; or that the right of eligibility was limited to persons of particular families or fortunes; or at least that the mode prescribed by the State constitutions was, in some respect or other, very grossly departed from.

See also id. No. 58, at 361 (James Madison) ("Were the defensive privilege limited to particular cases, an interested minority might take advantage of it to screen themselves from equitable sacrifices to the general weal, or, in particular emergencies, to extort unreasonable indulgences."); id. No. 62, at 378 (James Madison) ("But as the larger States will always be able, by their power over the supplies, to defeat unreasonable exertions of this prerogative of the lesser States ... ."); id. at 381 ("Another effect of public instability is the unreasonable advantage it gives to the sagacious, the enterprising, and the moneyed few over the industrious and uniformed mass of the people.").

254. See id. No. 38, at 233 (James Madison) ("Is it an unreasonable conjecture . . .."); id. No. 83, at 496 (Alexander Hamilton) ("If such a supposition would be unnatural and unreasonable .....). As Justice Scalia has pointed out, the writings by Hamilton and Madison in The Federalist are relevant to a textualist interpretation of the Constitution "not because they were Framers ... but rather because their writings, like those of other intelligent and informed people of the time, display how the text of the Constitution was originally understood." Scalia, Common-Law Courts, supra note 220, at 38 .

255. See Thomas Paine, Common Sense 43 (Bobbs-Merrill 1953) (1776):

It is unreasonable to suppose that France or Spain will give us any kind of assistance if we mean only to make use of that assistance for the purpose of repairing the breach and strengthening the connection between Britain and America, because those powers would be sufferers by the consequences.

256. See, e.g., Sims Lessee v. lrvine, 3 U.S. (3 Dall.) 425, 459 (1799) (Iredell, J., concurring) (" $\mathrm{A}] \mathrm{s}$ it might be an unreasonable thing, to burden any one state with the whole of these provisions, some modification of the title might be expected, so as to prevent this injury."); Pennington v. Scott, 2 Dall. 94, 95 (Pa. 1786) ("Having . . pursued every prepatory step, which the law requires, to procure the attendance of the witness, we think it would be unreasonable to take advantage of any accident, that may have happened to the messenger."); Ogden v. Ash, 1 Dall. 162, 164 (Pa. C.P. 1786) ("it might not be an unreasonable suspicion in the underwriters"); Respublica v. De Longchamps, 1 Dall. 111, $117\left(\mathrm{~Pa}\right.$. Oyer \& Terminer 1784) ( ${ }^{[}[\mathrm{T}]$ he princes of the world, at this day, are more enlightened, and do not require impractical nor unreasonable reparations for injuries of this kind.").

257. See supra note 227.

258. U.S. Const. amend. III. 
generally that in "Suits at common law ... the right of trial by jury shall be preserved." 259 The Fourth Amendment itself couples a general prohibition of "unreasonable searches and seizures" with a specific guarantee widely understood, then and now, to have been protected by common law: the rule that "no Warrants shall issue, but upon probable cause, supported by Oath or affirmation, and particularly describing the place to be searched, and the persons or things to be seized."260 Responding to comments on his Tanner Lectures, Justice Scalia argued that these detailed provisions shed light on the more general elements of the Bill of Rights. It is "reasonable to think," he contended, "that the provisions are all of a sort," and that "the abstract and general terms, like the concrete and particular ones, are meant to nail down current rights, rather than aspire after future ones-that they are abstract and general references to extant rights and freedoms possessed under the then-current regime." 261

This is a singularly frail line of reasoning, and a nice example of how the "plain meaning" of a text can reside in the eye of the beholder. The first problem is that Justice Scalia does not explain why it is "reasonable to think" that the terms of the Bill of Rights, so varied in appearance, are really "all of a sort." He refers elsewhere in his lectures to the "frequently used canon ... noscitur a sociis"- "it is known by its companions"-which Scalia takes to stand for "the principle that a word is given meaning by those around it." 262 He gives the following example: "If you tell me, 'I took the boat out on the bay,' I understand 'bay' to mean one thing; if you tell me, 'I put the saddle on the bay,' I understand it to mean something else."263 As the example suggests, though, the maxim noscitur a sociis typically is invoked when a court needs to choose between alternate definitions of a particular, ambiguous word, not to provide a narrow construction for language that on its face appears general. ${ }^{264}$ More importantly, the maxim-like most other canons of statutory construction-has

259. U.S. Const. amend. VII.

260. U.S. const. amend. IV. "General warrants" were condemned by Coke and Blackstone, struck down by British courts in a series of eighteenth-century cases celebrated throughout the colonies, see notes 345-352, 360-376 and accompanying text, and attacked by the Virginia Committee of Correspondence as "unknown to the common law," see Cuddihy, supra note 19, at 1114. James Otis, moreover, based much of his argument against the writs of assistance on the notion that the common law recognized only specific warrants for search or seizure. See John Adams, Abstract of the Argnment, in 2 Legal Papers of John Adams, supra note 143, at 134, 141-42. Nonetheless, the common-law ban on general warrants was far from complete. See infra text accompanying notes 343-382 and accompanying text.

261. Antonin Scalia, Response, in A Matter of 1nterpretation, supra note 220, at 129 , 135 .

262. Scalia, Common-Law Courts, supra note 220, at 26.

263. Id.

264. See Jarecki v. G.D. Searle \& Co., 367 U.S. 303, 307 (1961); 2A Norman J. Singer, Sutherland Statutory Construction $\$ 47.16$ (5th ed. 1992 \& Supp. 1999); cf. Mellinkoff, supra note 251, at 428 ("Some believe [the maxim] lends class (read 'pomp') to the commonplace that words are understood in the context of other words."). 
historically been understood as "a mere guide to legislative intent," which "will not be applied when there is no ambiguity." ${ }^{265}$ lndeed, judges often employ a countervailing principle, dubbed by one court "the 'knew how to' rule of statutory construction": when drafters use language of a certain kind in one place, their failure to use similar language elsewhere is assumed to be advertent. ${ }^{266}$ Thus we might say, pointing to the Seventh Amendment and perhaps also to the Warrant Clause, that the Framers knew how to codify common law explicitly, and that the term "unreasonable" in the Fourth Amendment should therefore be read to mean no less than what it says.

1t was precisely this kind of indeterminacy, arising from pairs of opposing if not mutually contradictory rules, that Karl Llewellyn lampooned in his well-known table of "thrusts" and "parries,"267 and that led to the low regard many lawyers, juidges, and scholars now have for canons of construction. Scalia complains in his Tanner Lectures that Llewellyn's attack was exaggerated, and insists that interpretation could and should be a "science." tific one-to believe that the various provisions of the Bill of Rights, regardless of their phrasing, should be deemed "all of a sort." 269

Nor is that the only problem with Scalia's argument. For even if the terms are considered "all of a sort," the question remains, which sort? Should the broadly worded clauses- "freedom of speech," "due process of law," "cruel and unusual punishments," "unreasonable searches and seizures"- be construed restrictively, to parallel the narrower guarantees-"keep and bear Arms," "compulsory process for obtaining witnesses," "trial by jury," "probable cause"? Or should the narrowly worded provisions be read expansively to resemble the more open-ended commitments? The text itself provides no answer. All the more reason for a true textualist to give each part of the Bill of Rights the meaning its words most naturally convey, and, in particular, to read the first clause of the Fourth Amendment to prohibit not just searches and seizures banned at common law, but all searches and seizures that are "unreasonable."

265. 2A Singer, supra note 264 at $\$ 47.16$; see also Joel Prentiss Bishop, Commentaries on the Written Laws and Their Interpretation $\$ 93$ (Boston, Little, Brown 1882) ("The meanings of the words . . will vary with the subject, context, and other circumstances; yet the legislature will be presumed to have intended what it said, and to have understood the significance of language." (footnotes omitted)). 1991).

266. In re Jones, 129 B.R. 1003, 1008 (Bankr. N.D. Ill.), aff'd, I34 B.R. 274 (N.D. IlI.

267. Karl N. Llewellyn, Remarks on the Theory of Appellate Decision and the Rules or Canons About How Statutes Are To Be Construed, 3 Vand. L. Rev. 395, 401-06 (1950).

268. Scalia, Common-Iaw Courts, supra note 220, at 14-15, 25-29.

269. Whether this failure is symptomatic of the broader vacuity of canons of construction is beyond the scope of this Article. For a recent effort to resurrect the canons, although only partially and as something far less than a "science of interpretation," see William N. Eskridge, Jr., Dynamic Statutory Interpretation 275-306 (1994). 
This is not the place to reopen the debate on whether it even makes sense to ask what meaning a set of words "naturally" conveys-whether, that is to say, there can be such a thing as a true textualist. ${ }^{270}$ My point here is more limited: whatever else it may tell us, the text of the Constitution alone does not tell us that searches and seizures are barred if and only if they were prohibited by common law. The words of the Fourth Amendment forbid "unreasonable searches and seizures," and nothing in the remainder of the document suggests that the facial meaning of these words should be disregarded. If the new Fourth Amendment originalism has any justification, it must be found elsewhere.

\section{B. Intent}

Although the Reasonableness Clause of the Fourth Amendment does not appear to codify eighteenth-century common law, it might make sense to read the provision that way, if that is what it was designed to accomplish. Justice Scalia, the principal advocate for the new Fourth Amendment originalism, purports to care only about " 'objectified' intent," i.e., the intent suggested by the text itself, "placed alongside the remainder of the corpus juris."271 "It is the law that governs," he explained in his Tanner Lectures, "not the intent of the lawgiver. . . What I look for in the Constitution is precisely what I look for in a statute: the original meaning of the text, not what the original draftsmen intended." 272 But even Justice Scalia finds it hard to ignore what he imagines the Framers had in mind. Thus, for example, he voices doubt in Minnesota $v$. Dickerson "whether the fiercely proud men who adopted our Fourth Amendment would have allowed themselves to be subjected, on mere suspicion of being armed and dangerous," to a frisk for weapons. ${ }^{273}$ Most people, on and off the bench, find arguments of that kind entirely proper. Indeed, many people believe that interpretation of any legal text-or any text at all, for that matter-should and perhaps must take into account what we think the authors intended. ${ }^{274}$ So even though Justice Scalia might disapprove, it is worth considering whether extratex-

270. The curious reader unfamiliar with this debate might begin with id. at 225-38; William D. Popkin, An "Internal" Critique of Justice Scalia's Theory of Statutory lnterpretation, 76 Minn. L. Rev. 1133 (1992); and Frederick Schauer, Statutory Construction and the Coordinating Function of Plain Meaning, 1990 Sup. Ct. Rev. 231.

271. Scalia, Common-Law Courts, supra note 220, at 17.

272. Id. at 17,38 .

273. 508 U.S. 366, 381 (1993) (Scalia, J., concurring). In Martinez v. Court of Appeal, Scalia argued:

I have no doubt that the Framers of our Constitution, who were suspicious enough of govenumental power-including judicial power-that they insisted upon a citizen's right to be judged by an independent jury of private citizens, would not have found acceptable the compulsory assignment of counsel by the Government to plead a criminal defendant's case.

120 S. Ct. 684, 693 (2000) (Scalia, J., concurring) (endorsing the judgment in Faretta v. California, 422 U.S. 806 (I975)).

274. See Davies, supra note 20 , at 740 n.555. 
tual evidence of the Framers' intent lends support to the new Fourth Amendment originalism.

There is a superficially appealing argument that it does. For the American revolutionaries not only knew and revered common law, they considered themselves its defenders. As Gordon Wood puts it, the colonists "revolted not against the English Constitution but on behalf of it"; they saw themselves as seeking “'only to keep their old privileges,' the traditional rights and principles of all Englishmen, sanctioned by what they thought had always been."275 Thus, the First Continental Congress declared that "the respective colonies are entitled to the common law of England,"276 and the Declaration of Independence was in large part an indictment of the king for alleged infringements on the historic rights of Englishmen. ${ }^{277}$ And, as we have seen, Otis and others leaned heavily on the common law in arguing against the writs of assistance. ${ }^{278}$ Those arguments, together with the English courts' celebrated invalidation of general warrants, have generally been thought the inspiration for the Fourth Amendment. ${ }^{279}$ So there are grounds for viewing the Fourth Amendment as an effort to secure rights already recognized by English law.

Justice Story, as we have seen, appeared to regard the provision this way; he described the Fourth Amendment in his Commentaries as "little more than the affirmance of a great constitutional doctrine of the common law." 280 Story was very much a jurist first and a legal historian second, ${ }^{281}$ but to a great extent his view of the Fourth Amendment remains conventional wisdom, for scholars as well as for judges. However widely their conclusions may differ about what the Fourth Amendment requires, many scholars share Story's assumption that the Amendment was in essence a "hallowing" of earlier protections. ${ }^{282}$

None of this, though, does much to support the new Fourth Amendment originalism. As I will discuss later, Cuddihy's work throws doubt on the received understanding of the Amendment's origin; in many ways, his research suggests, the provision broke with tradition rather than "hallowing" it. ${ }^{283}$ But for the moment put that problem to one side. Even Justice

275. Wood, supra note 232, at 10, 13 (quoting John Adams, Novanglus (1774), reprinted in 4 Works of John Adams 3, 131 (Boston, Little, Brown, 1851)).

276. Declaration and Resolves of the First Continental Congress (Oct. 14, 1774), in 1 Journals of the Continental Congress, 1744-1789, at 63, 69 (Worthington Chauncey Ford ed., 1904).

277. See Stoner, supra note 75 , at $185-90$.

278. See supra notes $229-233$ and accompanying text.

279. See supra note 230 ; infra text accompanying notes 360-376.

280. 2 Joseph Story, Commentaries on the Constitution of the United States $\$ 1902$, at 679 (3d ed., Boston, Little, Brown 1858); see supra text accompanying notes 89, 171.

281. See White, supra note 23, at 114-23; Jones, supra note 228, at 93-94.

282. Cuddihy \& Hardy, supra note 20, at 372 . For examples, see Bradford P. Wilson, Enforcing the Fourth Amendment: A Jurisprudential History 16 (1986); Amar, First Principles, supra note 17, at 764-67; Eric Schnapper, Unreasonable Searches and Seizures of Papers, 71 Va. L. Rev. 869, 875-76 (1985).

283. Cuddihy \& Hardy, supra note 20 , at 372. 
Story's view of the Fourth Amendment falls far short of justifying the new Fourth Amendment originalism. For it is one thing to understand the Amendment as solidifying past legal victories; it is quite another to interpret the ban on "unreasonable searches and seizures" as codifying the details of eighteenth-century common law-freezing them, as Professor Amar puts it, in constitutional amber. ${ }^{284}$

It is unlikely Justice Story himself meant to endorse the latter approach. The "great constitutional doctrine of the common law" he had in mind was probably not a set of specific rules, but rather the general tradition of disallowing unreasonable searches and seizures. ${ }^{285}$ Story elsewhere described the common law as "a system of elementary principles and of general juridical truths" that were "continually expanding" and "adapting" to changed circumstances and "the exigencies and usages of the country" - a system that differed sharply from the "fixed" and "inflexible" law set forth in statutes. ${ }^{286}$ That he understood the Fourth Amendment in particular to embody a "general truth" is suggested not only by his reference in the Commentaries to "a great constitutional doctrine of the common law," but also by the incredulity with which he treats Jefferson's argument that General Wilkinson was justified in what Story terms "a very gross violation" of the Fourth Amendment: "the seizure of two American citizens by military force, on account of supposed treasonable conspiracies against the United States, and transporting them, without any warrant, or order of any civil authority, from New Orleans to Washington for trial."287 Citing no treatises or decisions, Story suggests the constitutional defect was obvious: "Without any warrant or lawful authority, citizens are dragged from their homes under military force, and exposed to the perils of a long voyage, against the plain language of this very article." 288 if "unreasonable" means "contrary to a specific rule at

284. See Amar, First Principles, supra note 17, at 818.

285. The same may be said of then-Judge Cardozo's statement that New York's statutory version of the Fourth Amendment expressed "the principle that English law received as the outcome of the prosecutions of Wilkes and Entick" and that therefore " $[t]$ he immunity is not from all search and seizure, but from search and seizure unreasonable in the light of common-law traditions." People v. Chiagles, 142 N.E. 583, 583 (N.Y. 1923) (citations omitted). For Scalia's use of Chiagles, see supra note 100 and accompanying text.

286. Joseph Story, Codification of the Common Law, in The Miscellaneous Writings of Joseph Story 699, 702 (William W. Story ed., Boston, Little \& Brown 1852). On Story's view of common law, see generally Randall Bridwell \& Ralph U. Whitten, The Constitution and the Common Law 5-7 (1977).

287. 2 Story, supra note $280, \S 1902$, at $679-80$ n.2.

288. 1d. Story's argument about General Wilkinson's actions-"without any warrant, or order of any civil authority" - is hard to square with Professor Amar's suggestion, adopted from Telford Taylor, that warrants were universally viewed well into the nineteenth century not as sources of control but as devices themselves needing control, "friends of the searcher, not of the searched." Amar, First Principles, supra note 17, at 774; cf. Taylor, supra note 70, at 38-44. There is therefore some irony in the fact that Justice Scalia endorsed this suggestion the same month that he quoted with approval Justice 
common law," Story's argument here is blatantly incomplete. The argument makes a good deal more sense if we assume Story understood the opening clause of the Fourth Amendment to enshrine not a set of particulars, but an abstract principle, informed perhaps by the paradigm case to which he devoted the bulk of his one-page discussion of the Fourth Amendment: the general warrants struck down by English judges "almost upon the eve of the American revolution." 289

There is another, and for our purposes more important, reason to suspect that the "common law" to which Story referred in discussing the Fourth Amendment was abstract rather than particular: that appears to be the kind of "common law" most late-eighteenth-century Americans had in mind when they claimed to be rebelling "only to keep their old privileges." The common law Otis revered was the common law Coke had celebrated, a time-tested distillation of rules, maxims, and procedures. But in this respect Otis was behind the times. The American revolutionaries quoted Locke at least as often as they quoted Coke, and the rights Locke described were not rooted in centuries of judicial pronouncements. Indeed, appeals to ancient wisdom ran counter to the entire thrust of the Enlightenment. As a result, when the revolutionariesself-conscious products of the Age of Reason-spoke of "common law," they generally meant fundamental liberties, not specific rulings and practices. ${ }^{290}$

It is true they did not themselves draw this distinction as sharply as we would today. The rhetoric of the American Revolution was nothing if not eclectic, and consistency was not its greatest strength. ${ }^{291}$ The colonists characteristically spoke as if "all knowledge coincided."292 More particularly, Coke and Blackstone taught them that the common law was "the perfection of reason," seamlessly blending principle and practice. ${ }^{293}$ For most of the eighteenth century, Americans seemed to take this lesson quite seriously. They spoke of the common law as they spoke of "reason" more generally: as though its dictates were timeless, universal, and all of a piece. One sign of their outlook, as Morton Horwitz has noted, was their indifference to the antidemocratic aspect of common-law judging-

Story's statement that the Fourth Amendment is "little more than the affirmance of a great constitutional doctrine of the common law." See supra text accompanying notes 89-101. 289. 2 Story, supra note $280, \S 1902$, at 679 . Story's treatment of the Wilkinson episode makes it particularly unlikely that, as Professor Davies suggests, "the "great constitutional doctrine' he referred to was the illegality of general warrants." Davies, supra note 20 , at 618 n. 190 .

290. See Bailyn, supra note 73, at 175-89; Wood, supra note 232, at 9-10; Jones, supra note 228, at 110. Regarding the influence of French and English rationalism on lateeighteenth-century Americans, see Harold J. Berman, The Impact of the Enlightenment on American Constitutional Law, 4 Yale J.L. \& Human. 311 (1992). As Berman points out, there were important differences between Locke and the philosophes, but the colonists drew from both.

291. See Bailyn, supra note 73 , at 33-34; Wood, supra note 232 , at 6-7.

292. Wood, supra note 232 , at 7 .

293. See supra text accompanying notes 235-243. 
indeed, their apparent failure even to recognize the problem. ${ }^{294}$ At the center of Justice Scalia's Tanner Lectures was what he called "the uncomfortable relationship of common-law lawmaking to democracy."295 But despite the American revolutionaries' notorious suspicion of centralized power in every form, this was one kind of sovereignty that seemed to escape their gaze. They conceived of the common law as fixed, and so had no occasion to fear that it might permit judges to be arbitrary.

But this is still no reason to think the Fourth Amendment was intended to codify specific common-law rules. $1 n$ the first place, by the time the Bill of Rights was adopted in 1791, recognition had spread that discretion was inherent in the common law, and that common-law rules often sprang from something other than abstract reason and time-tested wisdom. Justice Scalia suggested in his Tanner Lectures that it was only in the twentieth century, "with the rise of legal realism, that we came to acknowledge that judges in fact 'make' the common law, and that each state has its own." ${ }^{296}$ ln fact, this acknowledgement began in the 1780 s and was well underway in the 1790s. ${ }^{297}$ By 1791, as Charles Wolfram has noted, "a commonly understood concept of 'common-law' had become that of a process characterized by occasional flexibility and capacity for growth in order to respond to changing social pressures, rather than that of a fixed and immutable body of unchanging rules." 298 That Madison, the principal author of the Bill of Rights, shared this view of the common law is suggested by his 1799 report on the Virginia resolutions concerning the Alien and Sedition Acts. Responding to the claim that the statutes were authorized by common law, Madison argued that "the common law was not the same in any two of the colonies"; that the common law had changed in the past and would change in the future; and that, were the common law "admitted as of legal or of constitutional obligation, it would confer on the judicial department a discretion little short of a legislative power." 299

It is a mistake, moreover, to exaggerate the earlier invisibility of common- law discretion. No one could mistake Coke or Blackstone for a legal realist, but both recognized that the law sometimes changed, and that some cases were decided wrongly. Coke, although "antiquarian to the

294. See Horwitz, supra note 233, at 4-9.

295. Scalia, Common-Law Courts, supra note 220, at 10.

296. Id. But see Davies, supra note 20 , at 725 (tracing the demise of "the notion of a permanent common law" to "the early nineteenth century").

297. See Horwitz, supra note 233, at 9-30, 253-66.

298. Charles W. Wolfram, The Constitutional History of the Seventh Amendment, 57 Minn. L. Rev. 639, 736 (I973). This view of the common law became especially pronounced a century later in the writings of Thomas Cooley-to whom, ironically, Justice Scalia has turned for guidance in interpreting the Fourth Amendment. See Brower v. County of Inyo, 489 U.S. 593, 596 (I989); supra note 71.

299. James Madison, Report on the Resolutions (Dec. 1799), reprinted in 6 The Writings of James Madison 341, 373, 379-81 (Gaillard Hunt ed., 1906). 
core," ${ }^{300}$ reminded his readers that "[o]ut of the ould Fields must spring and grow the new Corne." ${ }^{301}$ And Blackstone justified the traditional "encomiums on the reason of the common law" as in part a matter of terminology: "if it be found that the former decision is manifestly absurd or unjust, it is declared not that such a sentence was bad law, but that it was not law; that is, that it is not the established custom of the realm, as has been erroneously determined." 302 The colonists followed this linguistic convention in criticizing judicial decisions to which they objected, of which there were many-including, of course, the decisions granting writs of assistance. Otis himself argued it was "[b]etter to observe the known Principles of Law than any one Precedent, tho in the House of Lords." ${ }^{03}$ Back in England, Chief Justice Pratt sounded the same theme two years later in his celebrated decision striking down the general warrant used against John Wilkes: "no precedents, no legal determinations, not an Act of Parliament itself, is sufficient to warrant any proceeding contrary to the spirit of the constitution." 304 That a judge could be an instrument of tyranny the American revolutionaries thus were well aware, although they couched their fears in the language of Enlightenment rationalism. And at least some of them fully appreciated the pretense of that language. ${ }^{305}$ The most arresting evidence, perhaps, is Benjamin Franklin's wonderful account of his decision to forsake vegetarianism on the ground that since fish eat one another, he saw no reason why he should not eat fish. "So convenient a thing it is to be a reasonable Creature," Franklin concluded, "since it enables one to find or make a Reason for every thing one has a mind to do." 306

300. Mullett, supra note 73 , at 471 .

301. Edward Coke, Preface to 1 Les Reports de Sir Edward Coke (London, John Streater et al. 1672). Coke remarked on "the many changes and alterations of the common law, and additions to the same," Coke, The First Part of the Institutes, supra note 245, at 395, and he invited readers "to amend and correct" his own mistakes, Coke, The Second Part of the Institutes, supra note 236, at 744. He closed the Institutes with an aphorism he attributed to the sixteenth-century lawyer Edmund Plowden: "Blessed be the amending hand." Edward Coke, The Fourth Part of the Institutes of the Law of England 366 (4th ed., London, A. Crooke et al. 1669) (1644) [hereinafter Coke, The Fourth Part of the Institutes]. On Coke's view of changes in the law, see Stoner, supra note 75, at 22; Berman, supra note 72 , at 1680 \& n.75.

302. 1 Blackstone, supra note 143 , at $* 70$. Blackstone spoke of "the perfection ... now enjoy[ed]" by the laws of England, but he also boasted that those laws "have been and are every day improving," acknowledged they remained a "human structure" with "faults" and "defects," and called on Parliament and the nobility "[ $t]$ o sustain, to repair, to beautify this noble pile." 4 id. at *442-*443.

303. Adams, supra note 143 , at 127 .

304. Wilkes v. Wood, 98 Eng. Rep. 489, 490 (C.P. 1763).

305. See Horwitz, supra note 233, at 4-5.

306. Benjamin Franklin, The Autobiography 35 (1990); cf. id. at 162 ("The Conversation at first consisted of mutual Declarations of Disposition to reasonable Accommodation; but I suppose eacb Party had its own Ideas of what should be meant by reasonable."). 
The variability and the open-ended nature of common law, so clearly perceived by Madison and many of his contemporaries, have obvious implications for the merits of the new Fourth Amendment originalism as a remedy for the kind of subjective jurisprudence Justice Scalia decried in Ollman v. Evans, in his Tanner Lectures, and in his recent search-andseizure opinions. I will take up those implications shortly. For now, the important point is that the Framers' eighteenth-century rationalism offers little basis for concluding that they intended the opening clause of the Fourth Amendment to constitutionalize the then-existing rules of search and seizure. The common law revered by the Framers-the common law they thought timeless and universal-resided in fundamental principles, not in judicial precedents and statutory prescriptions.

It is of course possible that, if the Amendment was not intended to codify those precedents and prescriptions, they at least provide a strong indication of what practices the Framers considered "unreasonable." But that too seems improbable. Many of those who voted to adopt the Fourth Amendment may have read Blackstone, and some of them had also read Coke. But there is little evidence that most of them had mastered the common-law rules of search and seizure, let alone endorsed them. Even the search-and-seizure rulings of greatest interest to the American revolutionaries-those invalidating general warrants in the wake of the arrest of John Wilkes-were widely misreported in the colonies. ${ }^{307}$ And notwithstanding the revolutionaries' frequent invocation of Coke and Blackstone, many Americans of the late-eighteenth-century had a deep distrust of English common law. Jefferson's well-known disapproval of Blackstone $^{308}$ partly reflected, as Perry Miller demonstrated, a much broader, "nativist" strain in American thinking about the law, an ingrained antagonism "to any and every use of the English Common Law." 309 The hostility "was basically an inheritance from colonial experience; it had been strengthened by the patriotic hatred of everything British." ${ }^{10}$ This element of legal nativism made it unlikely that those who adopted the Fourth Amendment either intended it to codify common-law rules of search and seizure, or truly believed those rules to be the beginning and ending of wisdom on the subject. Tellingly, Massachusetts-the site of the strongest opposition to broad colonial searches, and the first state to adopt a provision barring "unreasonable searches and seizures"-abolished common law in 1641 as a basis for search and seizure. ${ }^{311}$

307. See Cuddihy, supra note 19 , at 1108-09.

308. See, e.g., Waterman, supra note 73 , at 634-38.

309. Miller, supra note 243 , at $105-05$.

310. Id.

311. See Cuddihy, supra note 19 , at $673-74$. On the exceptionally strong restrictions colonial Massachusetts placed on searches and seizures-including the restrictions later codified in the Warrant Clause of Fourth Amendment-see Cuddihy \& Hardy, supra note 20, at 392-98. 
Furthermore, even if the searches and seizures barred by eighteenthcentury common law were the searches and seizures the Framers deemed "unreasonable," it is difficult to characterize codification of those rules as the "intent" of the Fourth Amendment-assuming for the sake of argument that a coherent intent can be ascertained. The problem is the proper level of generality: whether, in Ronald Dworkin's familiar terms, the Amendment embodies a "conception" or a "concept." 312 Did the Framers intend us to shun the searches and seizures that they thought unreasonable, or those that we conclude are unreasonable, using our own best judgment? This kind of question can rarely if ever be answered with confidence for any constitutional provision-not only because of the usual difficulties of reconstructing a (possibly mythical) collective intent, but also because, in practice, abstract intentions and specific understandings often are intertwined. As Paul Brest has pointed out, a "principle does not exist wholly independently of its author's subjective, or his society's conventional exemplary applications, and is always limited to some extent by the applications they found conceivable. Within these fairly broad limits, however, the adopters may have intended their examples to constrain more or less." 313 Disentangling concepts and conceptions is particularly daunting when dealing with the original Constitution and the Bill of Rights, written and adopted by a generation that spoke so often as though the dictates of reason were universal, timeless, and all of a piece.

Nonetheless, even most dyed-in-the-wool originalists concede that certain constitutional provisions seem to cry out for open-ended interpretation-seem to embody abstract concepts rather than particular conceptions. Chief Justice Rehnquist, for example, is no believer in a "living Constitution." He devoted a lecture in 1976 to attacking the very notion. ${ }^{314}$ But Rehnquist thought "scarcely anyone would disagree" that when the Framers "spoke in general language" they "left to succeeding generations the task of applying that language to the unceasingly changing environment in which they would live." ${ }^{315}$ And few parts of the Constitution seem to call more loudly for this kind of interpretation than the opening clause of the Fourth Amendment. The term "unreasonable," as Professor Steiker has noted, "positively invites constructions that change with changing circumstances." 316 Professor Amsterdam, who generally found the text and history of the Fourth Amendment so uninstructive, reached the same conclusion: "What we do know, because the language

312. See Ronald Dworkin, Taking Rights Seriously 134-37 (1977).

313. Brest, supra note 227, at 217. For similar arguments, see, e.g., Terrance Sandalow, Constitutional Interpretation, 79 Mich. L. Rev. 1033, 1035-36 (1981); Laurence H. Tribe, Comment, in A Matter of Interpretation, supra note 220, at 68-72.

314. See William H. Rehnquist, The Notion of a Living Constitution, 54 Tex. L. Rev. 693,694 (1976).

315. 1d.

316. Steiker, Second Thoughts, supra note 18 , at 824 . 
of the fourth amendment says so, is that the framers were disposed to generalize to some extent beyond the evils of the immediate past." 317

For a professed textualist like Justice Scalia, that language should perhaps be dispositive. But even those unsympathetic to Justice Scalia's brand of textualism have reason to give the broad, open-ended ban on "unreasonable searches and seizures" its natural import. First, the choice of language appears to have been deliberate. This is suggested not only by comparison with other provisions of the Bill of Rights, ${ }^{318}$ but also by the available extraneous evidence of the Framers' intent-scanty and unreliable as it is. The Congressional records are too meager to offer any real guidance. ${ }^{319}$ But it is noteworthy that during the debates at the state level over ratification of the proposed Constitution, those concerned about the search-and-seizure powers of the federal government consistently called for an amendment restraining those powers "within proper bounds," or forbidding "all unreasonable searches and seizures." 320 No one proposed a constitutional ban on searches and seizures "contrary to common law," or "currently illegal under state law." 321 Second, whatever the Framers' expectations were regarding the kinds of searches and seizures that would be deemed "unreasonable," their larger expectation appears to have been that the Constitution would be interpreted "by reference to the intrinsic meaning of its words or through the usual judicial process of case-by-case interpretation," as statutes traditionally had been interpreted by common- law courts. ${ }^{322}$ Although they "accepted the inevitability and propriety of construction," they anticipated that departures from their literal language would be occasioned by new and unforeseen circumstances, not by efforts to give effect to their own, unexpressed intentions. ${ }^{323}$

1 have not mentioned certain other problems encountered in any attempt to construe the Bill of Rights according to the "Framers' intent"-e.g., who counts as a "Framer" of the first ten amendments, and what bearing, if any, do their intentions have on the meaning of the Due Process Clause of the Fourteenth Amendment, through which the Supreme Court has found most of the Bill of Rights applicable to the states?324 My point here is that reference to the Framers' expectations,

317. Amsterdam, supra note 15 , at 399.

318. See supra text accompanying note 266.

319. See Amar, First Principles, supra note 17, at 775 n.66; James H. Hutson, The Creation of the Constitution: The Integrity of the Documentary Record, 65 Tex. L. Rev. 1, 35-38 (1986).

320. Cuddihy, supra note 19 , at $1386-88$.

321. Id.

322. H. Jefferson Powell, The Original Understanding of Original Intent, $98 \mathrm{Harv}$. L. Rev. 885, 903-04 (1985); see Stoner, supra note 75, at 205-10, 221-22.

323. See Powell, supra note 322, at 904 .

324. On the latter question, see Akhil Reed Amar, The Bill of Rights and the Fourteenth Amendment, 101 Yale L.J. 1193, 1260-61 (1992); Steiker, Second Thoughts, supra note 18 , at 846 . 
like reference to the plain meaning of the text, cannot justify the new Fourth Amendment originalism-even assuming the general coherence of textualism, or of interpretation that purports to defer to authorial intent. If there is any basis for tying the constitutional "reasonableness" of a search or seizure to its validity under eighteenth-century common law, it must be found in considerations of a different sort.

\section{Structure}

Justice Scalia has not seriously tried to defend the new Fourth Amendment originalism based on the plain terms of the Amendment or on extratextual evidence of the Framers' Intent. Instead, he has suggested that Fourth Amendment "reasonableness" should be tied to eighteenth-century common law to serve what he perceives to be basic goals of our constitutional system: restraining majoritarian excesses and limiting the antidemocratic risks inherent in the delegation of authority to unelected judges. Thus, he argued in County of Riverside $v$. McLaughlin that "the function of the Bill of Rights" was to "preserve" certain judgments "not only against the changing views of Presidents and Members of Congress, but also against the changing views of Justices whom Presidents appoint and Members of Congress confirm to this Court." $325 \mathrm{He}$ complained in Minnesota $v$. Dickerson that asking whether searches and seizures are "'reasonable' by current estimations" reflects the "good-policy-is-constitutional-law school of jurisprudence." ${ }^{26}$ And in Minnesota $v$. Carter he attacked the "reasonable expectation of privacy" test for a search or seizure as "self-indulgent." 327 In practice, he charged, the expectations of privacy that, according to the Court, "'society is prepared to recoguize as "reasonable"" . . bear an uncanny resemblance to those expectations of privacy that this Court considers reasonable." 328

These arguments are consistent with the position Justice Scalia staked out in his Tanner Lectures. The "whole purpose" of a constitution, he contended, "is to prevent change-to embed certain rights in such a manner that future generations cannot readily take them away." 329 Viewing constitutional commands as open-ended therefore misses their point; it turns the judiciary from a principled guardian of fixed limits on government into just another political branch, distinguished only by its lack of democratic accountability. Without some "rock-solid" point of reference, the Constitution serves only "to take the power of changing rights away from the legislature and give it to the courts" 330

325. 500 U.S. 44, 60 (1991) (Scalia, J., dissenting).

326. 508 U.S. $366,380,382$ (1993) (Scalia, J., concurring).

327. 525 U.S. 83, 97 (1998) (Scalia, J., concurring).

328. Id. (quoting Katz v. United States, 389 U.S. 347, 361 (1967) (Harlan, J., concurring)).

329. Scalia, Common-Law Courts, supra note 220, at 40 .

330 . Id. at 41,47 . 
These are familiar concerns, and they are not without weight. ${ }^{331} \mathrm{~A}$ Fourth Amendment that prohibited all searches and seizures that happened to strike the Supreme Court as "unreasonable," and only those searches and seizures, would do both too much and too little. ${ }^{332}$ And Justice Scalia is not alone in thinking such a Fourth Amendment too close for comfort to the one we now have. ${ }^{333}$ Nonetheless the structural case for the new Fourth Amendment originalism has at least two serious weaknesses.

The first, to which I return below, is that it shares some of the evil it seeks to remedy: the untethered exercise of judicial power. By its terms the Fourth Amendment does not codify eighteenth-century common law, and the available evidence suggests that was not its purpose. For courts to read common law into the provision, in order to let it better accomplish what they take to be its basic function, is to engage in precisely what Scalia condemns: de facto amendment of the Constitution by unelected judges. It is, to be sure, a reasoned departure from the text, not the indulgence of mere wbim. But that much can in truth be said of most judgemade Fourth Amendment law-including, for example, the warrant requirement Scalia singled out for criticism in Califormia v. Acevedo. ${ }^{334}$

The second weakness, and the one on which I wish now to focus, is that common law is a far less secure tether for Fourth Amendment rights than Scalia has suggested. In part this is due to the discretion judges must inevitably exercise in deciding whether or not common law provides an "answer" to modern search and seizure questions, notwithstanding changed circumstances. ${ }^{335}$ But there is a more basic problem. More often than not, eighteenth-century "common law" itself is wildly indeterminate-so mucb so that the new Fourth Amendment originalism may make search-and-seizure law more rather than less responsive to the vicissitudes of judicial predisposition.

1. The Indeterminacy of Common Law. - The difficulty begins with the term itself. One meaning of "common law," of course, is law developed entirely by judges-court decisions based on other court decisions. This

331. See, e.g., Wilson, supra note 282, at 7 n.7 ("Surely rights are more secure when they are understood to have a fixed content rather than a content that changes with shifts in public sentiment.").

332. Even Justice Stewart, who wrote for the majority in Katz and joined the Court's opinion in Terry, feared that " $[\mathrm{u}]$ nder such an unconfined analysis, Fourth Amendment protection ... would approach the evaporation point." Chimel v. California, 395 U.S. 752, 765 (1969). Justice Frankfurter, in a frequently cited dissent, was still blunter: "It is no guide at all . . . to say that an 'unreasonable search' is forbidden-that the search must be reasonable. What is the test of reason which makes a search reasonable?" United States v. Rabinowitz, 339 U.S. 56, 83 (1950) (Frankfurter, J., dissenting).

333. See Chandler v. Miller, 520 U.S. 305, 323 (1997) (Rehnquist, C.J., dissenting); Skinner v. Railway Labor Executives' Ass'n, 489 U.S. 602, 639 (1989) (Marshall, J., dissenting); New Jersey v. T.L.O., 469 U.S. 325, 358 (1985) (Brennan, J., dissenting).

334. 500 U.S. 565, 581 (1991) (Scalia, J., concurring); see supra text accompanying notes $91-104$.

335. See supra text accompanying notes 216-218. 
is the common law of the late nineteenth century, the common law restated in the Restatements. But it is not the common law of Coke and Blackstone. It could not have been, not only because Coke saw no sharp distinction between statutes and precedents, but also because seventeenth- and eighteenth-century case law was simply too thin. So Coke and Blackstone augmented their case citations with copious references to statutes and previous commentators; their "common law" was an amalgam of cases, statutes, commentary, custom, and fundamental principles. ${ }^{336}$ They wrote as if all these sources of authority cohered and converged. The law was the "perfection of reason," timeless and universal.

One residue of their approach is the ability most lawyers still acquire to speak knowingly of "the common law" as though the phrase, standing alone, were utterly unambiguous. This is how Justice Scalia and Justice Thomas speak in their recent Fourth Amendment opinions. To find the rule "at common law" they look sometimes to cases, sometimes to statutes, sometimes to commentaries. They refer interchangeably to authorities from the 1600s and 1700s-and sometimes also from the 1800s and early 1900s. They mix together English and American materials. Like Coke and Blackstone, in short, they treat the common law as a unified, systematic body of rules, constant across space and time. ${ }^{337}$

But of course it was nothing of the kind. Perry Miller was closer to the mark in calling pre-industrial common law "a haphazard accumulation of precedents, quirks, and obscurities . . . fundamentally irrational by its inherent nature." 338 And, as Americans in the late-eighteenth-century increasingly recoguized, the accumulation changed over time and varied according to location. ${ }^{339}$ "Nowhere in Britisb North America," for example, "was the Englisb common law received lock, stock and barrel," and by the time of independence "common law doctrine exist[ed] in America not in a single authorized version but in thirteen." ${ }^{440}$ Cuddihy shows that search-and-seizure rules, in particular, varied from colony to colony and from decade to decade; he also shows that, in both England and America,

336. See Boorstin, supra note 242 , at 114-15; Corwin, supra note 73 , at 85-86; Mullet, supra note 73 , at 459 .

337. Justice Thomas makes the same mistake in turning to common law for "the original meaning of the Fifth and Sixth Amendments." Apprendi v. New Jersey, $120 \mathrm{~S}$. Ct. 2348, 2378 (2000) (Thomas, J., concurring); see also id. at 2383 (O'Connor, J., dissenting) (noting that Thomas "divines the common-law understanding of the Fifth and Sixth Amendment rights by consulting decisions rendered by American courts well after the ratification of the Bill of Rights, ranging primarily from the 1840 's to the 1890 's"). Professor Davies rightly criticizes judges and scholars who fail to distinguish common-law decisions predating the Fourth Amendment from those decided afterward. See Davies, supra note 20 , at $639 \mathrm{n} .252$. But even he tends to treat eighteenth-century common law as geographically uniform and fully determinate. See id. at 578-82, 585 n.93.

338. Miller, supra note 243 , at 121 .

339. See supra text accompanying note 298-299.

340. Jones, supra note 228, at 98; see Wolfram, supra note 298 , at 665,734 . 
theory and practice often diverged..$^{341}$ So whether a specific practice "was regarded as an unlawful search or seizure under the common law when the [Fourth] Amendment was framed"342 frequently depends on where one looks-England or America, Massachusetts or Maryland-and on what materials one examines-cases, statutes, commentaries, or practice manuals.

Consider, for example, the second clause of the Fourth Amendment, providing that "no Warrants shall issue, but upon probable cause, supported by Oath or affirmation, and particularly describing the place to be searched, and the persons or things to be seized." 343 Justice Scalia, like many others, sees the Warrant Clause as simply codifying a settled precept of the common law. ${ }^{344}$ In fact, common law authorities on the subject were inconsistent. True, Coke and Blackstone both condemned some warrants now prohibited by the Warrant Clause, as did, even more influentially, Coke's younger contemporary Matthew Hale. But the terms of their condemnations differed. According to Coke, a warrant authorizing forcible entry of a person's home could issue only following indictment for a felony: neither arrest warrants, nor warrants to search for stolen goods, could issue on "bare surmise." 345 Hale found these rules both too protective of felons and contrary to "the constant and usual practice." 346 He therefore allowed arrest warrants for suspected felons based on sworn testimony setting forth the grounds for suspicion. ${ }^{347}$ Hale wrote that arrest warrants "ought regularly to mention the name of the party to be attached," but he made an exception for warrants to arrest rioters who reassemble after an order to disperse. ${ }^{348}$ Similarly, he approved warrants to search for stolen property "in such particular places, where the party assigns before the justice his suspicion and the probable cause thereof," 349 although he acknowledged that "general warrant[s] to

341. See Cuddihy \& Hardy, supra note 20, at 375-400; Cuddihy, supra note 19 , at 374, $1256,1277,1302,1327$.

342. Wyoming v. Houghton, 526 U.S. 295, 299 (1999).

343. U.S. Const. amend. IV.

344. See Scalia, Common-Law Courts, supra note 220, at 134-35; Stoner, supra note 75 , at 211,265 n.64.

345. Coke, The Fourth Part of the Institutes, supra note 301, at 176. Coke allowed arrest warrants to ensure the peaceful apprehension of suspected felons, but opined that such warrants could not authorize forcible entry into a suspect's home, "for it is in law the arrest of the party that hath the knowledge or suspition, who cannot break open any house." Id. at 177. Coke acknowledged that homes of "poore and base people" often were searched with warrants issued on mere suspicion, but he warned that "if it be lawfull, the houses of any subject, be he never so great, may be searched, \& by such Warrant upon bare surmises." ld. at 178. Regarding the influence of Coke's views on warrants, see Cuddihy, supra note 19 , at 235 .

346. 2 Matthew Hale, History of the Pleas of the Crown 107, 113, 149 (London, Emlyn 1778). On Hale's influence on search-and-seizure law, see Landynski, supra note 8 , at 26-27; Lasson, supra note 250, at 35-37; Cuddihy, supra note 19, at 539-42, 548.

347. See 2 Hale, supra note 346, at 110.

348. ld. at 114-15.

349. Id. at 150 . 
search in all suspected places" were "usual" and supported by precedent. ${ }^{350}$ For his part, Blackstone had nothing to say about search warrants, but he endorsed Hale's position that arrest warrants could issue on suspicion supported by sworn testimony, and he went further than Hale in opposing any "general warrant" calling for the arrest of all those guilty or suspected of a particular crime "without naming or particularly describing any person in special." ${ }^{351}$ Blackstone categorically rejected all such warrants as "illegal and void," explaining that "it is the duty of the magistrate, and ought not to be left to the officer to judge of the ground of suspicion." 352

Not only did the warrants disapproved by Coke, Hale, and Blackstone differ, but the actual practice of the seventeenth and eighteenth centuries routinely involved the issuance of warrants that all three writers would have condemned. Both of the sample warrants in the initial, 1618 edition of Michael Dalton's magistrate's manual authorized indiscriminate, house-to-house searches: one "[t]o Search for stolen goods," and the other "for a generall search for Rogues." ${ }^{353}$ Similar warrants appeared in every subsequent edition of Dalton's work, as well as in other popular form books of the 1600s and 1700s, both in England and in the colonies. $^{354}$ During this period the use of narrower warrants slowly

350. Id. at 114, 150. On the question of whether a search warrant for stolen goods could authorize the forcible entry of a home, Hale took contradictory positions, first declaring that it could not, then asserting that it could. Compare id. at 114, 116-17, with id. at 151 .

351. 4 Blackstone, supra note 143 , at $* 291$.

352. Id.; cf. Money v. Leach, 97 Eng. Rep. 1075, 1088 (K.B. 1765) (Mansfield, C.J.) ("It is not fit, that the receiving or judging of the information should be left to the discretion of the officer. The magistrate ought to judge; and should give certain directions to the officer."). Two further aspects of Blackstone's selectivity are worth noting. First, the Commentaries took note of the decision by the King's Bench in Money $v$. Leach, but not the more far-reaching decisions by Chief Justice Pratt, Iater Lord Camden, in Wilkes v. Wood, 98 Eng. Rep. 489, 498 (C.P. 1764), and Entick v. Carrington, 95 Eng. Rep. 807, 817-I8 (C.P. 1765). See 4 Blackstone, supra note 143 , at $* 291 \mathrm{n} . \mathbf{k}$; infra text accompanying notes 365-376. Second, Blackstone asserted that after the decision in Money $v$. Leach, "the issuing of such general warrants was declared illegal by a vote of the House of Commons." 4 Blackstone, supra note 143 , at $* 291$ n.k. This left the impression that the House of Commons had barred all warrants calling for the arrest of unnamed and unspecified individuals, but in fact a bill to that effect failed. The House resolved only that general warrants were illegal in libel cases, breached privilege when executed against members of the House, and were unlawful in other cases-unless Parliament had authorized their use. See Lasson, supra note 250, at 49; Cuddihy \& Hardy, supra note 20, at 386; Cuddihy, supra note 19, at 953-67. The last proviso, Cuddihy notes, "practically nullified the resolve," because "the basis of most general searches was statute rather than custom." Cuddihy, supra note 19 , at 965 .

353. Cuddihy, supra note 19 , at $95 \&$ nn.41-42 (quoting Michael Dalton, The Covntry Ivstice 314, 318-19 (London, I618)). Late-seventeenth-century examples of both kinds of warrants are provided in Alan Macfarlane \& Sarah Harrison, The Justice and the Mare's Ale 90, 106 (1981).

354. See Cuddihy \& Hardy, supra note 20, at 387; Cuddihy, supra note 19, at 46-47, $96,252-53,347-51,1279-80$. Hale, despite disapproving "the general warrant to search all 
spread, and by the time of the American Revolution general warrants to search house-to-house for stolen property had largely disappeared from the form books. ${ }^{355}$ But the manuals continued to include form warrants authorizing indiscriminate searches for "rogues and vagabonds" and impost searches wherever the officers executing the warrant suspected they would find taxahle items. ${ }^{356}$ Some of these warrants, and others authorizing indiscriminate searches, may have been specifically authorized by statute-even, following the Revolution, in several states with constitutions that appeared to require that warrants specify the places to be searched. ${ }^{357}$ Before the Revolution, Cuddihy shows, the only colony to abandon indiscriminate warrants across the board was Massachusettswhich, siguificantly, began the process by rejecting the common law as a basis for search or seizure. ${ }^{358}$ And despite the teachings of Hale and Blackstone on probable cause, both before and after the Revolution most warrants in England and America were supported only by the applicant's bald assertion that grounds existed for the search or seizure: by practice

places, whereof the party and officer have suspicion," acknowledged that Dalton's manual condoned "such general warrants." 2 Hale, supra note 346, at 114. Dalton's second edition in 1626 added two more form warrants, one authorizing a search of "all inns, alehouses, and other suspected places" following robberies by persons unidentified, and one directing constables "to make search" for particular individuals suspected of robhery, and to raise the "hue and cry" for their capture. Cuddihy, supra note 19, at 95-96 \& nn.43-44 (quoting Michael Dalton, The Covntry Ivstice 354-55 (London, 1626)). "In context, 'to make search' was unmistakable shorthand for 'search every house that you suspect." Cuddihy, supra note 19 , at 96 . For examples of both these kinds of warrants, see Macfarlane \& Harrison, supra note 353 , at $47,87,106-07$.

355. See Cuddihy, supra note 19 , at 665-71, 1139, 1298-1302.

356. See Cuddihy \& Hardy, supra note 20, at 382-83; Cuddihy, supra note 19 , at 971-73, 1139-40. In addition, "[g]eneral warrants remained the only kind of warrant available for the hue and cry in the colonial legal manuals of 1761-1776, even though searchers were often cautioned against hreaking into a house unless they were certain, not just suspicious, that the suspect was inside." Cuddihy, supra note 19, at 1139.

357. See Cuddihy, supra note 19, at 1277, 1328-41. Professor Davies claims that Cuddihy misreads the statutes. See Davies, supra note 20, at 655 n.299. The matter is murky, because most of the statutes Cuddiby cites authorize warrants to search "any house," but do not specify the "probable cause" required for issuance of a warrant. They thus may be read, as Davies suggests, to allow the search of any house, but only pursuant to a warrant to search that particular house based on prohable cause to suspect that contraband would be found there. See id. New York's 1784 impost law, though, was less amhiguous, and it appears to support Cuddihy's claim. Based on prohable cause to "suspect that any person or persons have landed removed or reshipped any goods wares or merchandise ... without due entry thereof made, or without having paid or secured to be paid the duties thereon," the New York statute required issuance of a warrant "to enter into any house outhouse or other building or enclosure in the day time, where such goods wares or merchandize are suspected to be deposited or concealed." An Act imposing duties on certain goods wares and merchandize imported into this State, 8 th sess., ch. 7 (1784), reprinted in 2 Laws of the State of New York 11, 17 (Albany, Weed Parsons \& Co. 1886).

358. See Cuddihy \& Hardy, supra note 20, at 392-98; Cuddihy, supra note 19, at $672-75,1299$. 
and in some cases by statute, magistrates rarely asked to hear the grounds, let alone assessed their adequacy. ${ }^{359}$

Of course, no statute, practice manual, or commentator-not even Coke or Blackstone-shaped the thinking of late-eighteenth-century Americans on the subject of search and seizure as powerfully as the judicial invalidation in the $1760 \mathrm{~s}$ of broad warrants executed in London against John Wilkes, John Entick, and others suspected of involvement with their dissident publications. ${ }^{360}$ Coming on the heels of the unsuccessful argument by James Otis against the Massachusetts writs of assistance, and arising out of "the first and only major litigation in the English courts in the field of search and seizure," ${ }^{361}$ these rulings attracted extraordinary attention and acclaim throughout the colonies. ${ }^{362}$ They therefore constitute a particularly important part of the common-law background to the Fourth Amendment. If the Amendment aimed to codify any part of the common law, perhaps, it was these celebrated cases.

So it is especially damaging to the structural argument for the new Fourth Amendment originalism that these cases, too, fail to establish unambiguously the requirements set forth in the Warrant Clause of the Amendment-or, for that matter, any other rule of general application. The ambiguity is twofold. First, the warrants invalidated in the $1760 \mathrm{~s}$ were objectionable in several different respects: they called for the ransacking of entire houses and the wholesale scrutiny of private papers; they were aimed at muzzling critics of the government; they were issued not by a judge or magistrate but by the secretary of state; they left considerable discretion in the hands of the officers; and they lacked any clear statutory authorization. ${ }^{363}$ As Eric Schnapper has pointed out, "[o]nly the most extreme situations will involve the same combination of aggravating factors." 364 Second, there were five pertinent appellate rulings, they differed in their reasoning, and there is no agreement on which was the most important. In Wilkes v. Wood-which Professor Amar calls "the paradigm search and seizure case" for late-eighteenth-century Americans ${ }^{365}$ Cbief Justice Pratt of the Court of Common Pleas condemned warrants that gave "discretionary power" to officers "to search wherever their suspicions may chance to fall." 366 Not even "an Act of Parliament itself" could make such a warrant lawful, because it was "contrary to the spirit of the

359. See Cuddihy, supra note 19 , at $673,1192-94,1351-52$.

360. See Entick v. Carrington, 95 Eng. Rep. 807 (C.P. 1765); Money v. Leach, 97 Eng. Rep. 1075 (K.B. 1765); Beardmore v. Carrington, 95 Eng. Rep. 790 (C.P. 1764); Wilkes v. Wood, 98 Eng. Rep. 489 (C.P. 1763); Huckle v. Money, 95 Eng. Rep. 768 (C.P. 1763).

361. Taylor, supra note 70 , at 26 .

362. See Cuddihy, supra note 19, at 1104-10. On the writs of assistance controversy, see supra note 230 and accompanying text.

363. See Lasson, supra note 250 , at $42-48$; Taylor, supra note 70 , at 29-35; Cuddihy, supra note 19 , at $886-927$.

364. Schnapper, supra note 282 , at 916 (footnote omitted).

365. Amar, First Principles, supra note 17, at 772.

366. 98 Eng. Rep. 489,498 (C.P. 1763). 
constitution" and "totally subversive of the liberty of the subject." 367 In Money $v$. Leach - the only ruling on the matter by the King's Bench, and the only case in the series mentioned by Blackstone ${ }^{368}$ _Lord Mansfield agreed that warrants should "give certain directions to the officer," but only when Parliament had failed to provide specific authorization for broader warrants. ${ }^{369}$. Writs of assistance for searches by revenue agents, and general warrants to search for vagrants, were thus fully lawful. ${ }^{370} \mathrm{En}$ tick v. Carrington - wbich Cuddihy treats as "the definitive precedent," 371 other scholars have called "the most renowned of the decisions," 372 and Justice Bradley singled out as "one of the landmarks of English liberty"373 - struck down a warrant that, unlike the warrant in Wilkes and Leach, named the individual against whom it was directed and whose house it authorized searching. ${ }^{374}$ Writing again for the Court of Common Pleas, Pratt-now Lord Camden-this time stressed the intrusiveness of paper searches rather than the discretion left to the officers, and the lack of statutory authorization rather than the limits of legislative power. ${ }^{375}$ Without approval from Parliament, he reasoned, warrants could not authorize the wholesale seizure of a libel suspect's papers, particularly without a prior judicial proceeding, because the practice had no ancient common-law precedent, and "would destroy all the comforts of society." 376

The multiple evils presented by the secretarial warrants, and the multiple reasons given for their invalidation, make these cases a kind of doctrinal Rorschach test, amenable to any number of readings. For Blackstone, the rulings simply reaffirmed Hale's condemnation of a "general warrant to apprehend all persons suspected, without naming or particularly describing any person in special"- the condemnation later codified in the "particularity" requirement of the Fourth Amendment. ${ }^{377}$ In Schnapper's view, and Justice Bradley's, the chief message of the rulings is that papers enjoy special protection from search or seizure. ${ }^{378}$ Amar suggests that they stand for the central role that civil juries should play in evaluating, post hoc, the reasonableness of government searches and

367. Id. at $490,498$.

368. See 4 Blackstone, supra note 143 , at *291 n.k; supra note 352 . Amar, in contrast, treats Money $v$. Leach simply as a "companion case" to Wilkes $v$. Wood. Amar, First Principles, supra note 17 , at 776 .

369. 97 Eng. Rep. 1075, 1088 (K.B. 1765).

370. See Cuddihy, supra note 19 , at $909,924,988$.

371. Id. at 915.

372. Schnapper, supra note 282 , at 876 ; see Landynski, supra note 8 , at 29 ("the most famous case").

373. Boyd v. United States, 116 U.S. 616, 626 (1886).

374. 95 Eng. Rep. 807, 808 (C.P. 1765)

375. See id. at 817 .

376. Id. at $815-18$.

377. 4 Blackstone, supra note 143 , at *291.

378. See Boyd, 116 U.S. at 630; Schnapper, supra note 282 , at 880-84. 
seizures. ${ }^{379}$ And Justice Powell read the cases to insist, above all else, that government searches and seizures should take place only after a judicial assessment of the grounds for the intrusion ${ }^{380}$ - the very "warrant requirement" that Amar, with Justice Scalia and Professor Taylor, attacks as groundless. ${ }^{381}$ Blackstone's view is plausible, but so are the others. The "lessons" of the secretarial warrant cases-lessons that Amar, like Justice Bradley and Justice Powell, believes "the Fourth Amendment was undeniably designed to embody"- thus remain very much up for grabs. In particular, these cases do not demonstrate what many people assume they do: that the Warrant Clause of the Fourth Amendment merely codified protections well established at common law. ${ }^{382}$

The concrete requirements of the Warrant Clause are the only part of the Fourth Amendment with clear roots in all of the Amendment's state constitutional antecedents. ${ }^{383}$ If the common law is unclear regarding even these rules, one might expect still greater ambiguity on other issues of search and seizure. And that is what one finds.

Take, for example, the question of warrantless arrests. Two decades ago the Supreme Court held that an officer with probable cause to believe a suspect has committed a felony may arrest the suspect without a warrant, in part because that was "the ancient common-law rule," 384 but refused to apply the rule to routine arrests in private homes, in part because "the common-law rule on warrantless home arrests was not as clear as the rule on arrests in public places." 385 As the Court noted, commonlaw commentators differed widely on the latter question: some, including Coke, disallowed warrantless entries for purpose of arrest, except in case of hot pursuit; others, including Blackstone, allowed such entries; and

379. See Amar, First Principles, supra note 17, at 776 .

380. See United States v. United States Dist. Court, 407 U.S. 297, 316 (1972).

381. See supra text accompanying notes $101 \&$ 153-155. Justice Frankfurter, despite his strong defense of the warrant requirement, seemed to share Blackstone's view of the cases. See Harris v. United States, 331 U.S. 145, 164-74 (1947) (Frankfurter, J., dissenting). Professor Davies, too, reads the cases to confirm the illegality of the general warrant. See Davies, supra note 20 , at 655 . But he also agrees with Powell that the cases reflected a broader " $\mathrm{h}]$ ostility to conferring discretionary search authority on common officers." Id. at 578-80.

382. Amar, First Principles, supra note 17, at 772.

383. See Lasson, supra note 250, at 79-82; Cuddihy, supra note 19, at 1233-55.

384. United States v. Watson, 423 U.S. 411,418 (1976). The Court also stressed that federal and state statutes had long authorized warrantless, probable-cause arrests, and that a contrary rule would "encumber criminal prosecutions with endless litigation with respect to the existence of exigent circumstances, whether it was practicable to get a warrant, whether the suspect was about to flee, and the like." Id. at 420-24.

385. Payton v. New York, 445 U.S. 573, 596 (1980). The Court noted that "[n]one of the federal statutes cited in the Watson opinion" explicitly authorized warrantless entries into homes, and that state statutes did not exhibit "the kind of virtual unanimity on this question that was present in . . Watson." Id. at 600-01. And the Court reiterated the "'basic principle of Fourth Amendment law' that searches and seizures inside a home without a warrant are presumptively unreasonable." Id. at 586 (quoting Coolidge v. New Hampshire, 403 U.S. 443, 477 (1971)). 
still others, including Hale, appeared to equivocate. ${ }^{386}$ In truth, even the rule regarding arrests in public places was far from clear-cut. Dissenting from the ruling requiring warrants for arrests in a residence, Justice White pointed out that for most of the history of the common law, "any arrest on bare suspicion-even one occurring outside the home-was open to question." 387 Blackstone, for example, allowed warrantless arrests only in cases "of felony actually committed, or a dangerous wounding, whereby felony is like to ensue."388 Justice White, echoing other writers, traced the rule "that the constable could arrest on suspicion even if it turned out that no felony had heen committed" to Lord Mansfield's 1780 decision in Samuel $v$. Payne. ${ }^{389}$ But as Jerome Hall pointed out over sixty years ago, that decision held only that a constable lacking personal knowledge of an offense could arrest based on a citizen's complaint; there was no finding regarding whether a felony had actually been committed, and it seems likely that one had been. ${ }^{390}$ Hall showed that the English rule allowing officers to arrest on probable cause without a warrant, regardless whether a felony had actually occurred, in fact dated back only to 1827.391 In view of this history, he concluded, "the broad assertion that a police officer could without a warrant arrest for felony 'at common law' even though no felony had been committed, becomes at best so crude and ambiguous as to be totally misleading. One does not usually think of 1827 as tantamount to 'at common law.' "392 More to the present point, a rule announced by the King's Bench in 1827 says little about what "was regarded as an unlawful search or seizure under the common law when the Amendment was framed." 393

386. Id. at 593-96 (citing, inter alia, 4 Blackstone, supra note 143 , at $* 292$; Coke, The Fourth Part of the Institutes, supra note 301 , at $177 ; 1$ Hale, supra note 346 , at 583; 2 id. at 90-95). Hale initially declared that "[a] man that arrests upon suspicion of felony, may break open doors, if the party refuses upon demand to open them," 1 Hale, supra note 346, at 583, but later suggested, as the Payton Court noted, that a constable had this power only when in hot pursuit, see 2 id. at 92; Payton, 445 U.S. at 595 \& n.41.

387. Payton, 445 U.S. at 607 (White, J., dissenting).

388. 4 Blackstone, supra note 143, at *292 (emphasis added).

389. Payton, 445 U.S. at 607 (citing Samuel v. Payne, 99 Eng. Rep. 230 (K.B. 1780)) For a similar attribution, see 9 Halsbury's Laws of England 298 \& n.x (1909).

390. See Jerome Hall, Legal and Social Aspects of Arrest Without a Warrant, 49 Harv. L. Rev. 566, 570-71 (1936).

391. See id. at 575-76 (discussing Beckwith v. Philby, 6 B. \& C. 635 (K.B. 1827)); see also Davies, supra note 20, at 627-42 (reaching the same conclusion as Professor Hall).

392. Hall, supra note 390 , at 590 .

393. Wyoming v. Houghton, 526 U.S. 295, 299 (1999). Additionally, even if the common-law rule were clear, its application to present-day arrests would not be, because many more crimes are classified as "felonies" today than in the eighteenth century. See Davies, supra note 20 , at $630 \&$ n.220. Justice Marshail stressed this point in arguing that "the balance struck by the common law . . . decreed that only in the most serious of cases could the warrant be dispensed with," and that “ $[t]$ his balance is not recognized when the common-law rule is unthinkingly transposed to our present classifications of criminal offenses." United States v. Watson, 423 U.S. 411, 441-42 (1976) (Marshall, J., dissenting). The Court made a similar point a decade later when rejecting, for purposes of determining 
Or take the issue in County of Riverside v. McLaughlin: the permissible period of delay between a warrantless arrest and a judicial determination of probable cause. ${ }^{394}$ Justice Scalia differed with the McLaughlin majority in two respects. He thought the outside limit should be twenty-four hours instead of forty-eight hours, and he thought that no delay should be permitted merely to facilitate combining the probable cause hearing with other proceedings, such as the setting of bail. ${ }^{395} \mathrm{He}$ acknowledged that the common law could not answer the first question: the allowable delay before a probable cause hearing, "given the functions the officer is permitted to complete beforehand," was "obviously a function not of the common law but of helicopters and telephones." 396 But he suggested that the common law predating the Fourth Amendment gave "a clear answer" to the second question: "the only element bearing upon the reasonableness of delay was ... the arresting officer's ability, once the prisoner had been secured, to reach a magistrate who could issue the needed warrant for further detention."397

It is no accident that the earliest of the fourteen cases Scalia cited for this "clear answer" was decided in 1860. Common-law decisions of the late 1800 s and early 1900 s were less emphatic than Scalia indicated regarding the permissible grounds for delaying a probable cause hearingas indeed Scalia's own authorities made clear. ${ }^{398}$ But at least they insisted on the broader principle, held in common by Scalia and the McLaughlin majority, that a suspect arrested without a warrant must be brought before a magistrate as soon as "reasonably" possible. Earlier authorities were equivocal even on this broader point. Hale, for example, wrote simply that a constable who arrests suspects without a warrant "may convey them to the sheriff, or his gaoler of the county," although "the safest and best way . . . is to bring them to a justice of peace."399 Likewise "[i]f a hue and $c r y$ be raised against a person . . . the constables, and those that follow the hue and cry, may arrest and imprison him in the common gaol, or

"reasonableness" under the Fourth Amendment, common-law authorities permitting the use of deadly force to stop any fleeing felon. See Tennessee v. Garner, 471 U.S. 1, 14 (1985).

394. 500 U.S. 44 (1991); see supra text accompanying notes 82-90.

395. See McLaughlin, 500 U.S. at 68 (Scalia, J., dissenting).

396. Id. at 62 n.1.

397. Id. at $60-61$.

398. See, e.g., Venable v. Huddy, 72 A. 10, 11 (N.J. I909) (opining that “ $[t] h e$ detention of the plaintiff was justified for the length of time only reasonably required to take him to the magistrate and procure the warrant, having due regard inter alia to judicial accessibility, convenience, practice, and facilities" (emphasis added)); Hayes v. Mitchell, 69 Ala. 452,455 (1881) (declaring that after a warrantless arrest the marshal "would be authorized to imprison the offender, until he could be properly brought to trial"). Scalia cited Hayes for the proposition that the only factor justifying delay was ability to reach a magistrate, and Venable for the broader principle that a postarrest hearing on probable cause must be held as soon as "reasonably" possible. See McLaughlin, 500 U.S. at 61 .

399. 2 Hale, supra note 346 , at 95 . 
carry him to a justice of peace." 400 And night watchmen were empowered "to arrest such as pass by until the morning, and if no suspicion, they are then to be delivered, and if suspicion be touching them, they shall be delivered to the sheriff, viz. to the common gaol, there to remain until they be in due manner delivered." 401 Blackstone suggested that an arrestee "ought regularly to be carried before a justice of the peace," but, like Hale, he said nothing about timing. ${ }^{402}$

Or take Justice Scalia's conclusion in Minnesota $v$. Dickerson that "the 'stop' portion of the Terry 'stop-and-frisk' holding accords with the common law," but that Terry frisks stand on shakier ground. ${ }^{403}$ Scalia reached this conclusion because the common law allowed the temporary detention of so-called night-walkers, but he could find "no clear support at common law" for physically searching a suspect who had not been arrested. ${ }^{404}$ But the treatment of night-walkers is weak precedent for Terry stops. Hale's discussion, quoted in the previous paragraph, indicates their detention typically lasted all night and was treated as an arrest. Blackstone suggests the same thing: watchmen "may arrest all offenders, and particularly night-walkers, and commit them to custody till the morning." 405 And the absence of "clear support at common law" for searching suspects without arresting them is unremarkable: as Cuddihy demonstrates, common law had almost nothing to say ahout any searches of persons, arrested or not. ${ }^{406}$ Cuddihy does conclude that, at the level of actual practice, colonial arrests were regularly accompanied by body searches. ${ }^{407}$ Since, however, the "detention" of night-walkers was in fact a

400. Id. at 102 (fifth emphasis added).

40I. Id. at 96. Scalia cited a footnote in the first American edition of Hale's treatise, published in the mid-nineteenth century, for the proposition that "a person arresting a suspect without a warrant must deliver the arrestee to a magistrate 'as soon as he reasonably can." McLaughlin, 500 U.S. at 61 (quoting 2 Matthew Hale, History of the Pleas of the Crown 95 n.13 (Philadelphia, Robert H. Small 1847)). But the footnote was not Hale's; it was added by the American annotators.

402. 4 Blackstone, supra note 143 , at $* 296$.

403. 508 U.S. 366, 380-82 (1993) (Scalia, J., concurring).

404. Id

405. 4 Blackstone, supra note 143 , at $* 292$. Indeed, there was authority "that one may be indicted for being a common night-walker, as for a misdemeanor." 1 Edward Hyde East, Pleas of the Crown 303 (London, J. Butterworth \& J. Cooke 1803). East drew heavily on William Hawkins's early-eighteenth-century treatise, and Scalia cited both authors for the proposition that "every private person may by the common law arrest any suspicious night-walker, and detain him till he give a good account of himself.' " Dickerson, 508 U.S. at 380 (emphasis added) (quoting 1 East, supra, at 303; 2 William Hawkins, Pleas of the Crown 129 (8th ed. I824)). But Hawkins and East, like other writers, differentiated the powers and duties of private persons from those of watchmen and other officers. See 1 East, supra, at 303 (noting that peace officers "are required to apprehend [night-walkers] till morning that they may be examined"); 2 William Hawkins, Pleas of the Crown 80 (2d ed., London, J. Walthoe 1724) (noting the requirement in the Statute of Winchester (1285) "[t]hat if any Stranger do pass by the Watch, he shall be arrested until Morning").

406. Cuddihy, supra note 19 , at 846, 1518-19, I552.

407. See id. at $1516-18$. 
form of arrest, their treatment necessarily justifies Terry frisks to the same extent it justifies Terry stops.

Scalia doubted in Dickerson "whether the fiercely proud men who adopted our Fourth Amendment would have allowed themselves to be subjected, on mere suspicion of being armed and dangerous," to the "indignity" of a weapons frisk. ${ }^{408}$ There are good reasons to doubt that, but there are also good reasons-aside from Justice Scalia's own professed textualism-to think the question largely irrelevant. The "fiercely proud men" who comprised the electorate in 1791 approved all kinds of searches for other people they would never have tolerated for themselves. The overwhelming impression conveyed by the rhetoric of the Revolutionary era is that American merchants and landowners objected to virtually any intrusions on their persons or property by officers of the Crown. Much of the rhetoric appealed unmistakably to class privilege: customs officers were denounced as "dirty," "insolent," "impertinent," "rude," etc. ${ }^{409}$ In this regard, as in others, Americans echoed the protests in England against the general warrants executed against John Wilkes and other government critics. ${ }^{410}$ On both sides of the Atlantic, the propertied spokesmen for the sanctity of the home had nothing to say about searches and seizures carried out by constables and watchmen-local officials more likely to defer to the gentry, and whose statutory responsibilities, in any event, turned their attention elsewhere. The class bias inherent in the routine arrest of night-walkers-the wealthy, after all, had little occasion to walk public roads after dark-typified the eighteenth-century law of search and seizure. Coke warned that searches allowed against "poore and base people" might later be exercised against others, ${ }^{411}$ but his worry was not widely shared: "English law aimed less at abolishing discretionary intrusions than at confining them within certain social and occupation boundaries." 412 Peers and members of Parliament received special protections against search and seizure, while the homes of the poor were freely inspected for vagrants, poached game, and morals violations. ${ }^{413}$ Colonial statutes largely followed the same pattern and added, in the South, the innovation of the slave patrol: military squads that, operating largely at night, rounded up drifters and routinely invaded "Ne-

408. Dickerson, 508 U.S. at 381.

409. Cuddihy, supra note 19 , at $1019,1117,1127$; Davies, supra note 20 , at 577-78.

410. See Cuddihy, supra note 19 , at 949,961 .

411. See supra note 345 .

412. Cuddihy \& Hardy, supra note 20 , at 380 .

413. See id.; Cuddihy, supra note 19, at 43, 187, 668, 831. "Many 'minority' opponents of secretarial warrants observed that general privy searches were entirely proper remedies for vagrants, whom some dismissed as 'pests of society.' Mansfield reminded his audience in [Money $v$. Leach] that vagrancy warrants and writs of assistance were among 'many cases' of general warrants that legislation had preserved." Cuddihy, supra note 19 , at 988 . 
gro Houses" and other dwellings that might harbor or provide arms to escaped slaves. ${ }^{414}$

The elitism of eighteenth-century search-and-seizure law does not just make it a less attractive touchstone for constitutional reasonableness; it also renders the new Fourth Amendment originalism utterly incompatible with any inquiry into whether the Framers "would have allowed themselves to be subjected to" a particular form of intrusion. By that measure, the vast majority of searches and seizures thought reasonable in 1791 were unconstitutional-as are most searches and seizures tolerated today.

The foregoing pages have made clear, 1 hope, that any jurisprudence that ties Fourth Amendment reasonableness to "the common law when the Amendment was framed" necessarily leaves a good deal up for grabs. 1 do not want to overstate. Not all appeals to common law are equally unconvincing, and as to a few matters-e.g., the legality of searching an arrestee-eighteenth-century practice may have been relatively uniform. 1t is therefore possible that the new Fourth Amendment originalism will make search-and-seizure law, if not stable and predictable, at least more stable and more predictable than it used to be. Even that may be doubted, for reasons 1 discuss below. But the important point for now is that any improvement along these lines will be slight. The common law of search and seizure was far more fragmentary and far less consistent than might be imagined, and far less secure a tether for Fourth Amendment doctrine than Justice Scalia has suggested.

1 offer one final example-not actually involving common law, but instructive nonetheless. For purposes of determining what searches and seizures were deemed "reasonable" in the late-eighteenth-century, the evidence the Supreme Court has cited most often-including in Carroll v. United States, the current Court's favorite model of proper Fourth Amendment inquiry ${ }^{415}$ - consists of early federal statutes authorizing customs officers to search ships without warrants. 416 Warrants might be thought unnecessary in this setting for two different reasons: the searches were of vessels, and they took place at the nation's nautical border. This confluence of circumstances obviously makes the statutes doubtful precedent for border searches not involving vessels, and for searches of vessels away from the border-even granting, for the sake of argument, that automobiles and ships can sensibly be lumped together as "vessels." But the Supreme Court has persistently ignored this difficulty, using the statutes to justify both warrantless border searches of all kinds, and warrantless searches of cars throughout the nation. In customs cases the Court says the early statutes demonstrate the legality of "routine searches and

414. See Cuddihy, supra note 19 , at $838-39,867,1150-53,1276-95,1327$; Levy, supra note 20, at 240; Cuddihy \& Hardy, supra note 20, at 390-91.

415. 267 U.S. 132 (1925); see supra text accompanying notes 174-199.

416. See supra text accompanying notes $137-141,190$. 
seizures at the border"417; in car cases, like Carroll, the Court claims the statutes recognize the difference between "a dwelling house or similar place" and "a movable vessel." 418

If the secretarial warrant cases of the I760s are the doctrinal equivalent of an inkblot test, the Founding-era customs statutes resemble one of those drawings that can be seen in either of two ways: as a duck or a rabbit, or as a young or an old face. ${ }^{419}$ Both sets of precedents are inescapably equivocal. With this kind of ambiguity lurking not only in the principal inspiration for the Fourth Amendment but also in the most commonly invoked evidence of its original understanding, there can be little ground for expecting the new Fourth Amendment originalism, whatever else it does, to deliver much in the way of doctrinal stability. To be sure, it offers more guidance than simply asking the Supreme Court to decide, case by case, what searches and seizures strike it as "reasonable." But that is not the only alternative.

2. Constitutionalized Common Law and Common-Law Constitutionalism.Like many other self-professed "originalists," Justice Scalia often writes as though any departure from "original meaning" necessarily leads to a thoroughly subjective free-for-all, to adjudication by will rather than by reason. This is a large part of his argument in Ollman $v$. Evans. ${ }^{420} \mathrm{He}$ makes the point at length in his Tanner Lectures. ${ }^{421}$ And he sounds the same note in his recent Fourth Amendment opinions, contrasting his own position with what he calls "the original-meaning-is-irrelevant, goodpolicy-is-constitutional-law school of jurisprudence."422 Unless they stick to original meaning, Scalia suggests, judges are simply acting as legislators-something they have no business doing, and for which they have no special qualifications. Once the question is no longer what the Constitution "says" or "what it was understood to mean," but "what it should mean," there is no longer any reason to prize "impartiality,

417. United States v. Montoya de Hernandez, 473 U.S. 531, 537 (1985); accord United States v. Ramsey, 431 U.S. 606, 616-17 (1977).

418. Carroll, 267 U.S. at 151; accord e.g., Florida v. White, 526 U.S. 559, 563-64 (1999); Wyoming v. Houghton, 526 U.S. 295, 300-01 (1999); United States v. Ross, 456 U.S. 798, 806 \& n.8 (1982). For early criticism of Carroll on this score, see Black, supra note 176 , at 1075. Black's objection is echoed in Landynski, supra note 8 , at 90 .

419. For a nice collection, see J.R. Block \& Harold E. Yuker, Can You Believe Your Eyes? 15-29 (1992). The duck-rabbit figured famously in Ludwig Wittgenstein, Philosophical lnvestigations 194e (G.E.M. Anscombe trans., 2d ed. 1958). Wittgenstein found it in Joseph Jastrow, Fact and Fable in Psychology 295 (Boston, Houghton, Mittlin 1900), and Jastrow credited it to Harper's Weekly and the German humor magazine Die Fiegende Blätter. See id. The most familiar version of the young-old face appeared in Edwin G. Boring, A New Ambiguous Figure, 42 Am. J. Psychol. 444, 444 (1930). For its antecedents, see Edmond Wright, The Original of E G Boring's 'Young Girl/Mother-lnLaw' Drawing and lts Relation to the Pattern of a Joke, 21 Perception 273, 273 (1992).

420. 750 F.2d 970 (D.C. Cir. 1984) (en banc), cert. denied, 471 U.S. 1127 (1985); see supra text accompanying notes 31-45.

421. See Scalia, Common-Law Courts, supra note 220, at 38-47.

422. Minnesota v. Dickerson, 508 U.S. 366, 382 (1993) (Scalia, J., concurring). 
judgment, and lawyerly acumen," rather than democratic accountability, in those who provide the answer. ${ }^{423}$

But few people on or off the Court actually believe the Constitution means whatever "it should mean." This surely was not the premise from which Justice Frankfurter argued that the Fourth Amendment generally prohibits warrantless searches, nor was it the starting point for the Court's analysis in Katz v. United States or Terry $v$. Ohio, nor was it the basis of Justice Scalia's own search-and-seizure opinions in his early years on the Court. In each of these cases the argument, although not originalist, was hardly free-form. Rather it appealed to and was constrained by the Court's own prior decisions-what Justice Scalia called "tradition." Notwithstanding the notorious messiness of Fourth Amendment doctrine, the Justices customarily have approached the Fourth Amendment, as they have the rest of the Constitution, through the medium of earlier case law. The fundamental methods of American constitutional law are the fundamental methods of the common law: stare decisis and progressive elaboration. Constitutional law, that is to say, has taken the form of common law-as Justice Scalia himself has pointed out. ${ }^{424}$ The new Fourth Amendment originalism seeks to replace the form with the eighteenth-century content, swapping, we might say, common-law constitutionalism for constitutionalized common law.

Why make the swap? Justice Scalia simplifies the case by caricaturing both options. Constitutionalized common law offers stability, clarity, and objectivity; common-law constitutionalism amounts to saying the Constitution means whatever the Supreme Court on any given day wants it to mean. I have already described the exaggeration in the first of these descriptions; the second is equally overstated. Precedents never decide a case; they can always be distinguished, particularly when other precedents point the other way. And Fourth Amendment case law, so rife with

423. Scalia, Common-Law Courts, supra note 220 , at $46-47$; see also supra text accompanying notes $42-44$.

424. See Scalia, Common-Law Courts, supra note 220, at 39-40. Justice Scalia is far from the first to observe the common-law nature of constitutional adjudication, although he may be the first to find it an unmitigated evil. Usually those drawing the analogy think the common-law method a source of strength. See Brest, supra note 227, at 228-29; Jones, supra note 228, at 133-34; Sandalow, supra note 313, at 1055; David A. Strauss, Common Law Constitutional Interpretation, 63 U. Chi. L. Rev. 877, 888 (1996). Even Henry Monaghan, who argues in general against "the common law approach" in constitutional law, makes an exception for the Bill of Rights: it "was perhaps inevitable," he concedes, that judges interpreting those expansive provisions adopt "the incremental, case-by-case method employed by common law judges." Henry P. Monaghan, Our Perfect Constitution, 56 N.Y.U. L. Rev. 353, 392-93 (1981). Jane Schacter has recently argued that common-law techniques have also shaped the Supreme Court's approach to statutory interpretation, even when the Court purports to anchor its analysis in statutory text; she uses the phrase "common law originalism" to capture the hybrid nature of the Court's methodology. See Schacter, supra note 26, at 19-20. 
contradictions, may be especially pliable. ${ }^{425}$. Indeed, the "confusion" of search-and-seizure jurisprudence is part of what drove Justice Scalia in California v. Acevedo to ground Fourth Amendment reasonableness in eighteenth-century common law. ${ }^{426}$. But reasoning from prior decisions is different from writing on a blank slate, even when the prior decisions conflict with one another. One need not believe there is a "right" answer to every case to appreciate the discipline associated with offering reasoned justifications for following one line of authority instead of another-analogizing to certain cases, distinguishing others, seeking to separate the essential from the incidental. These practices carry with them real constraints. ${ }^{427}$

To a great extent, of course, the constraints are self-imposed, and not all judges take them seriously. There are judges who decide cases the way Benjamin Franklin says he abandoned vegetarianism, finding a reason for whatever they have a mind to do. ${ }^{428}$ But the new Fourth Amendment originalism will not constrain these judges; either the common law will "yield no answer" to the question before them, ${ }^{429}$ or the answer it yields will be the one they prefer. Doctrine of any kind can only guide judges who care about it. And for those judges, Fourth Amendment "tradition"-the incrementally evolving law of search and seizure-may offer at least as much direction as an instruction to follow eighteenth-century common law when it provides an "answer." Indeed in most cases traditional Fourth Amendment doctrine, often criticized for its excessive detail, ${ }^{430}$ may well provide more guidance than the spotty and disorganized rules of eighteenth-century common law. ${ }^{431}$

There is room for disagreement about that. But the additional stability promised by the new Fourth Amendment originalism is at best highly speculative. And, at least in the area of search and seizure,

425. But see Allen \& Rosenberg, supra note 21, at 1153-61 (arguing that "Fourth Amendment law is close to a model of clarity," and that "[v]irtually every significant aspect of human interaction has already been provided for in a relatively clear set of rules"). $91-104$

426. 500 U.S. 565, 583-84 (Scalia, J., concurring); see supra text accompanying notes

427. The past two decades have produced a large body of scholarship on the nature of those constraints. See, e.g., F.M. Kamm, Theory and Analogy in Law, 29 Ariz. St. L.J. 405, 412-14 (1997); Cass R. Sunstein, On Analogical Reasoning, 106 Harv. L. Rev. 741, 767-81 (1993).

428. See supra text accompanying note 306 .

429. Wyoming v. Houghton, 526 U.S. 295, 299 (1999); see supra text accompanying notes $216-218$.

430. See, e.g., Craig M. Bradley, The Failure of the Criminal Procedure Revolution 49-51 (1993); Amar, First Principles, supra note 17, at 757-61.

431. See generally Strauss, supra note 424 , at 926 (explaining that " $[\mathrm{t}]$ he notion that the text of the Constitution is an effective limit on judges is plausible only if one assumes a background of highly developed precedent"). For a cogent reminder that late-eighteenthcentury Americans relied on stare decisis to constrain the judicial power and to render its exercise principled, see Judge Richard Arnold's recent opinion in Anastasoff v. United States, No. 99-3917EM, 2000 WL 1182813 (8th Cir. Aug. 22, 2000). 
common-law constitutionalism has several important and much less speculative advantages over constitutionalized common law.

First, the guidance it provides is more accessible. However unsatisfying, the Supreme Court's prior interpretations of the Fourth Amendment are at least easy to locate. The same cannot be said for eighteenth-century rules of search and seizure. This is a matter of special consequence for a field of law that aims to guide not only judges in their cloistered chambers but also police officers in the field. ${ }^{432}$ The prosecutors and agency counsel who advise those officers will often find it difficult to predict from the Court's past statements what it will say in the future. But at least they know where to begin. Government lawyers can read and master the Court's Fourth Amendment jurisprudence; asking them to steep themselves in eighteenth-century common law is unrealistic.

The second advantage is greater fidelity to the constitutional text. The Fourth Amendment, it bears repeating, does not prohibit searches and seizures that are "contrary to common law;" it prohibits searches and seizures that are "unreasonable." As we have seen, there is little basis for suspecting the Amendment was originally understood as a shorthand codification of common- law rules of search and seizure. True, the Amendment also does not prohibit, by its terms, unreasonable searches and seizures "as that category shall be defined over time by the courts." But that reading accords far better than the new Fourth Amendment originalism with general expectations in the late- eighteenth-century about how the Constitution would be interpreted and applied. lt also amounts to an ongoing effort, through the most conventional of AngloAmerican jurisprudential techniques, to make sense of what the Constitution does explicitly require-freedom from "unreasonable searches and seizures."

The third clear advantage of Fourth Amendment "tradition" over the new Fourth Amendment originalism is greater candor. David Strauss has pointed out that the common-law method, by virtue of its qualified commitment to stare decisis, brings to the surface the choice in every case between following tradition and responding more directly to concerns of justice and practicality. ${ }^{433}$ ln contrast, he suggests, originalist approaches to constitutional interpretation tend to hide that choice by pretending it does not exist. ${ }^{434}$ When any deviation from the original meaning is labelled usurpation, the proper degree of judicial restraint becomes difficult-and unnecessary-for judges to discuss openly. The likely result is that the discussion never takes place, and that "[ $d]$ isputes that in fact concern matters of morality or policy masquerade as hermeneutic

432. I owe this point to Carol Steiker.

433. See Strauss, supra note 424 , at 879 .

434. See id. at 883 . 
disputes about the 'meaning' of the text, or historians' disputes about what the Framers did." 435

The new Fourth Amendment originalism works similarly, cloaking questions of fairness and expediency as historical inquiries into eighteenth-century common law. Justice Scalia's own search-and-seizure opinions offer useful points of comparison. His early opinions, as we have seen, explicitly opted to adhere to "tradition"-i.e., to the main currents of search-and-seizure doctrine, developed incrementally over decades by the Supreme Court. ${ }^{436}$ The element of choice was undisguised. Always implicit in the analysis was the assessment that the traditional rule had not been shown sufficiently unfair or impractical to justify a departure - and that, if such a showing had been made, nothing would prevent the Court from responding to it. Scalia's more recent Fourth Amendment opinions are different. Instead of making an explicit choice, they purport to apply an interpretive method that leaves no room for judgment.

Justice Scalia's search-and-seizure opinions illustrate a fourth and final advantage of the traditional, precedent-based approach to the Fourth Amendment: it capitalizes on the special skills not only of the lawyers who advise police officers, but also of judges-including Supreme Court justices-and the lawyers who argue before them. Again, Professor Strauss has made the point well:

It is not clear what, exactly, the distinctive lawyer's skills are, but the abilities required by the common-law method-proficiency in a form of moral casuistry (distinguishing cases, recognizing significant particular facts, and so on), a rough understanding of social science, and skill at certain kinds of textual interpretation-are good candidates. It is less clear why lawyers should be thought to have... . the historian's skills required by originalism . . . . ${ }^{437}$

Lawyers and judges may be better at legal history than at other kinds of history, but even legal history is not their strong suit. The dangers of pegging constitutional interpretation to eighteenth-century legal distinctions are well demonstrated by the Supreme Court's tortured efforts in Seventh Amendment cases to determine which modern actions would have been brought at common law in 1791 and which would have been brought at equity. 438 There, at least, the historical inquiry is suggested by the constitutional text, which "preserve[s]" the right to jury trial "[i]n

435. Id. at 928 . On the conversation-stopping tendency of originalist arguments, see White, supra note 23 , at $113-40$.

436. See supra text accompanying notes $46-63$.

437. Strauss, supra note 424 , at 932 .

438. See Chauffeurs, Teamsters \& Helpers, Local No. 391 v. Terry, 494 U.S. 558, 574-78 (1990) (Brennan, J., concurring); Mary Kay Kane, Civil Jury Trial: The Case for Reasoned Iconoclasm, 28 Hast. L.J. 1, 2-12 (1976); Wolfram, supra note 298, at 736-41. 
Suits at common law."439 Justice Scalia's recent Fourth Amendment opinions illustrate the same hazards, with less textual justification. ${ }^{440}$ Those opinions turn repeatedly on historical assertions that wilt under scrutiny: for example, that eighteenth-century common law plainly required all arrested suspects to be brought before magistrates as soon as physically possible, or that the common law unambiguously permitted brief investigative stops based on reasonable suspicion. ${ }^{441}$

Often the merit of a jurisprudential approach is difficult to disentangle from the skill and character of the judges applying it; that is why it is so helpful to compare Justice Scalia's later Fourth Amendment opinions with his earlier ones. As judicial craft, the early opinions hold up a good deal better. One can quarrel with Scalia's reading of Fourth Amendment "tradition" in these cases, but his reading is always plausible. This is not to say the earlier decisions never lapse into overstatement. In his majority opinion in Arizona $v$. Hicks, for example, Justice Scalia asserts that "[n]othing" in the Court's prior opinions supported a distinction between a "cursory inspection" and a "full-blown search"-ignoring the glaring example of Terry frisks. ${ }^{442}$ Similarly, arguing for the Court in Griffin $v$. Wisconsin that judicial warrants based on a reduced level of probable cause are flatly impermissible, he distinguishes administrative warrants-which the Court has held do not require the normal showing of probable cause-on the makeshift and entirely novel ground that administrative warrants "do not necessarily have to be issued by courts." ${ }^{433}$ But the overstatements in the earlier opinions, unlike those in the later ones, are not critical to Scalia's entire argument. There are obvious differences between a Terry frisk and a cursory inspection of a turntable, as in Hicks,

439. U.S. Const., amend. VII; see Martin H. Redish \& Daniel J. La Fave, Seventh Amendment Right to Jury Trial in Non-Article III Proceedings: A Study in Disfunctional Constitutional Theory, 4 Wm. \& Mary Bill Rts. J. 407, 412-14 (1995).

440. So does the recent effort by Justice Thomas to anchor Fifth and Sixth Amendment rights in eighteenth-century common law. See Apprendi v. New Jersey, $120 \mathrm{~S}$. Ct. 2348, 2367 (2000) (Thomas, J., concurring); supra note 337.

441. See supra text accompanying notes 394-414. Professor Davies is thus right to complain that "modern judges have not been particularly successful in recounting the content of framing-era law," Davies, supra note 20, at 742, although, for reasons 1 have tried to make clear, he is wrong to attribute the problem solely to their failure to examine "the historical sources" with sufficient care and disinterest, id. at 55I, 734-35. I take Davies's ultimate position regarding the "[i]nescapability of [d]octrinal [c] hange" to be broadly consistent with the one I defend here. Id. at 747-50. He criticizes efforts to move Fourth Amendment analysis to "a higher level of abstraction," id. at 746, but elsewhere suggests that search-and-seizure doctrine should seek "to preserve a meaningful "right to be secure' in the modern context," id. at 741, 749-50.

442. 480 U.S. $321,328-29$ (1987).

443. 483 U.S. $868,877-78$ (1987). As Justice Blackmun pointed out in dissent, the Court's earlier opinions had plainly contemplated that administrative warrants would be issued by the judiciary; here as elsewhere, the whole point of requiring warrants was to " "provide assurances from a neutral officer that the inspection is reasonable under the Constitution.'" Id. at 882 n.1 (Blackmun, J., dissenting) (quoting Marshall v. Barlow's, Inc., 436 U.S. $307,323(1978))$. 
to see whether it is stolen: Terry frisks, for one thing, are aimed at protecting the safety of police officers, a goal that seems more important than identifying stolen property. And administrative warrants, with their relaxed version of probable cause, are freakish even by the standards of search-and-seizure jurisprudence; Justice Scalia was on firm ground in finding the overall "body of Fourth Amendment law" inconsistent with warrants based on something less than the normal level of probable cause. ${ }^{444}$

In Hicks and in Griffin, as in all of Justice Scalia's early Fourth Amendment decisions, the argument rests on a distillation of prior case law. This kind of distillation is a large part of what lawyers are trained to do, so it should come as no surprise that Scalia always does a respectable job of it. His arguments along these lines can always be challenged-that is the nature of the common-law enterprise, and among its chief attractions. But they cannot be dismissed as simply shoddy; they are not premised on an illusion. If the new Fourth Amendment originalism prompts fresh attention to the virtues of the old, common-law method of developing search-and-seizure law-and constitutional law more generally-it will have performed a great service.

\section{CONCLUSION}

The Supreme Court says lots of things it turns out not to mean. But the Court's recent statements giving eighteenth-century common law a central role in the identification of "unreasonable searches and seizures"-what 1 have been calling the new Fourth Amendment originalism-deserve to be taken seriously. They are not the products of sloppiness, nor do they seem to express a passing fancy. Rather they represent the culmination of a campaign fought for close to a decade by Justice Scalia, assisted latterly by Justice Thomas. And the new Fourth Amendment originalism really is new. 1t departs dramatically from the largely ahistorical approach the Court has taken to the Fourth Amendment for most of the past thirty years, and it differs significantly from the use of history in earlier search-and-seizure opinions, stretching back to the nineteenth century. The Court has a long and celebrated tradition of looking to the background of the Fourth Amendment for the paradigmatic abuses that prompted its adoption, and then generalizing from those specific practices to the broader evils against which the Amendment offers protection. This is a far cry from saying, as the Court now has, that the first task in assessing a Fourth Amendment claim is determining whether the challenged action would have been condemned by common law in 1791 .

Unfortunately, the Court's new approach is not only innovative, it is also unjustified. 1t finds support neither in the constitutional text, nor in what we know of the intentions of the "Framers," however that term is

444. Griffin, 483 U.S. at 878. 
understood. And the new Fourth Amendment originalism will do little to make search-and-seizure doctrine more principled or predictable. $1 \mathrm{n}$ deed that goal may be better served by drawing from the common law what constitutional law has always drawn from it: not a set of substantive rules, but a centuries-old jurisprudential method, rooted in stare decisis and the practice of reasoned elaboration. That method ultimately may give judges no more leeway than the new Fourth Amendment originalism. 1t does, however, make the leeway more visible. This transparency is among the method's great virtues, not least because it makes clear what the Court's new approach tends to obscure: that the Fourth Amendment places on courts a burden of judgement, and that the burden cannot be relieved by the common law's sporadic, contradictory, and necessarily time-bound rules of search and seizure. 